\title{
Sacral nerve stimulation for faecal incontinence and constipation in adults (Review)
}

Thaha MA, Abukar AA, Thin NN, Ramsanahie A, Knowles CH

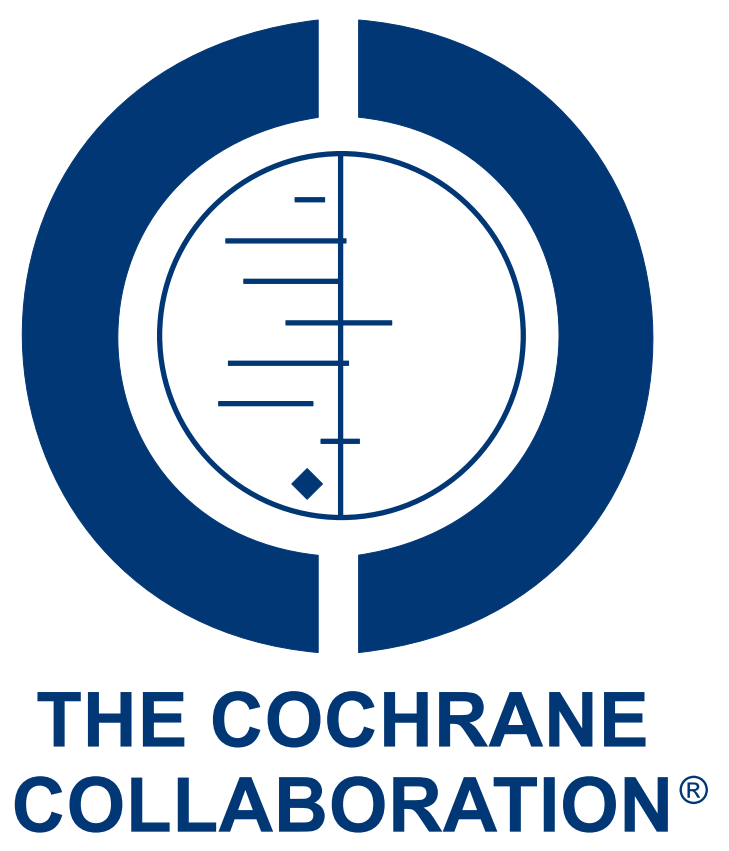

This is a reprint of a Cochrane review, prepared and maintained by The Cochrane Collaboration and published in The Cochrane Library 2015, Issue 8

http://www.thecochranelibrary.com

\section{WILEY}

Sacral nerve stimulation for faecal incontinence and constipation in adults (Review)

Copyright $\odot 2015$ The Cochrane Collaboration. Published by John Wiley \& Sons, Ltd. 
TABLE OF CONTENTS

HEADER . . . . . . . . . . . . . . . . . . . . . . . . . . . . . . . . . . . . . . . . . . . . . . . . . . . . . .

ABSTRACT . . . . . . . . . . . . . . . . . . . . . . . . . . . . . . . . . . . . . . . . . . . . . . . . . .

PLAIN LANGUAGE SUMMARY . . . . . . . . . . . . . . . . . . . . . . . . . . . . . . . . . . . . . . . . . . . .

BACKGROUND . . . . . . . . . . . . . . . . . . . . . . . . . . . . . . . . . . . . . 3

OBJECTIVES . . . . . . . . . . . . . . . . . . . . . . . . . . . . . . . . . . . . . . . . . . . . . . . . . . .

METHODS . . . . . . . . . . . . . . . . . . . . . . . . . . . . . . . . . . . . . . 6

RESUlTS . . . . . . . . . . . . . . . . . . . . . . . . . . . . . . . . . . . . . . . . . . . . .

Figure 1. . . . . . . . . . . . . . . . . . . . . . . . . . . . . . . . . . . . . . . . 9

Figure 2.

Figure 3. . . . . . . . . . . . . . . . . . . . . . . . . . . . . . . . . . . . . . 15

DISCUSSION . . . . . . . . . . . . . . . . . . . . . . . . . . . . . . . . . . . . . . . . . . . . . .

AUTHORS' CONCLUSIONS . . . . . . . . . . . . . . . . . . . . . . . . . . . . . . . . . . . . . . . . . . .

ACKNOWLEDGEMENTS . . . . . . . . . . . . . . . . . . . . . . . . . . . . . . . . . . . 24

REFERENCES . . . . . . . . . . . . . . . . . . . . . . . . . . . . . . . . . . . . . . . . . . . .

CHARACTERISTICS OF STUDIES . . . . . . . . . . . . . . . . . . . . . . . . . . . . . . . . . . . . . . . . . . .

DATA AND ANALYSES . . . . . . . . . . . . . . . . . . . . . . . . . . . . . . . . . . . . . . . . . . . . . . . . . . . . .

Analysis 1.1. Comparison 1 Faecal incontinence: parallel group data SNS vs medical therapy, Outcome 1 Episodes of faecal incontinence per week.

Analysis 1.2. Comparison 1 Faecal incontinence: parallel group data SNS vs medical therapy, Outcome 2 Days using pads per week.

Analysis 1.3. Comparison 1 Faecal incontinence: parallel group data SNS vs medical therapy, Outcome 3 Days with incontinence per week.

Analysis 1.4. Comparison 1 Faecal incontinence: parallel group data SNS vs medical therapy, Outcome 4 Days with faecal staining per week.

Analysis 1.5. Comparison 1 Faecal incontinence: parallel group data SNS vs medical therapy, Outcome 5 Cleveland Clinic Incontinence Score. . . . . . . . . . . . . . . . . . . . . . . . . . . . . . . . . 50

Analysis 1.6. Comparison 1 Faecal incontinence: parallel group data SNS vs medical therapy, Outcome 6 SF12 Physical. 50

Analysis 1.7. Comparison 1 Faecal incontinence: parallel group data SNS vs medical therapy, Outcome 7 SF12 Mental. 51

Analysis 1.8. Comparison 1 Faecal incontinence: parallel group data SNS vs medical therapy, Outcome 8 FIQL Lifestyle. 51

Analysis 1.9. Comparison 1 Faecal incontinence: parallel group data SNS vs medical therapy, Outcome 9 FIQL Coping/behaviour.

Analysis 1.10. Comparison 1 Faecal incontinence: parallel group data SNS vs medical therapy, Outcome 10 FIQL Depression/self perception.

Analysis 1.11. Comparison 1 Faecal incontinence: parallel group data SNS vs medical therapy, Outcome 11 FIQL Embarrassment.

Analysis 2.1. Comparison 2 Faecal Incontinence: parallel group data SNS vs PTNS, Outcome 1 Episodes of faecal incontinence per week.

Analysis 2.2. Comparison 2 Faecal Incontinence: parallel group data SNS vs PTNS, Outcome 2 Cleveland Clinic Incontinence Score. . . . . . . . . . . . . . . . . . . . . . . . . . . . . . . . . . . .

Analysis 2.3. Comparison 2 Faecal Incontinence: parallel group data SNS vs PTNS, Outcome 3 FIQL Lifestyle. . . $\quad 54$ Analysis 2.4. Comparison 2 Faecal Incontinence: parallel group data SNS vs PTNS, Outcome 4 FIQL Coping. . 55 Analysis 2.5. Comparison 2 Faecal Incontinence: parallel group data SNS vs PTNS, Outcome 5 FIQL Depression. . 55 Analysis 2.6. Comparison 2 Faecal Incontinence: parallel group data SNS vs PTNS, Outcome 6 FIQL Embarrassment. 56 Analysis 2.7. Comparison 2 Faecal Incontinence: parallel group data SNS vs PTNS, Outcome 7 EQ-5D. . . . . 56

ADDITIONAL TABLES . . . . . . . . . . . . . . . . . . . . . . . . . . . . . . . . . . . 77

APPENDICES . . . . . . . . . . . . . . . . . . . . . . . . . . . . . . . . . . . . . . . 77

WHAT'S NEW . . . . . . . . . . . . . . . . . . . . . . . . . . . . . . . . . . . . . . 79

HISTORY . . . . . . . . . . . . . . . . . . . . . . . . . . . . . . . . . . . . . . . . . . 79

CONTRIBUTIONS OF AUTHORS . . . . . . . . . . . . . . . . . . . . . . . . . . . . . . . . . . . . . 79

DECLARATIONS OF INTEREST . . . . . . . . . . . . . . . . . . . . . . . . . . . . . . . . . . . . . . . . . . . .

SOURCES OF SUPPORT . . . . . . . . . . . . . . . . . . . . . . . . . . . . . . . . . . . . . . . . . . . . . . . . . . .

Sacral nerve stimulation for faecal incontinence and constipation in adults (Review)

Copyright $\odot 2015$ The Cochrane Collaboration. Published by John Wiley \& Sons, Ltd. 1 .

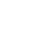


DIFFERENCES BETWEEN PROTOCOL AND REVIEW . . . . . . . . . . . . . . . . . . . . . . . . . . . 80

INDEX TERMS 


\title{
[Intervention Review]
}

\section{Sacral nerve stimulation for faecal incontinence and constipation in adults}

\author{
Mohamed A Thaha ${ }^{1 a}$, Amin A Abukar ${ }^{1 b}$, Noel N Thin ${ }^{1}$, Anthony Ramsanahie ${ }^{1}$, Charles H Knowles ${ }^{1}$ \\ ${ }^{1}$ Academic Surgical Unit, National Centre for Bowel Research \& Surgical Innovation, Centre for Digestive Diseases, Blizard Institute, \\ Barts \& The London School of Medicine \& Dentistry, Queen Mary University London, London, UK \\ ${ }^{a}$ These authors contributed equally to this work.. ${ }^{b}$ These authors contributed equally to this work. \\ Contact address: Mohamed A Thaha, Academic Surgical Unit, National Centre for Bowel Research \& Surgical Innovation, Cen- \\ tre for Digestive Diseases, Blizard Institute, Barts \& The London School of Medicine \& Dentistry, Queen Mary University Lon- \\ don, 1st Floor, Abernethy Building, 2 Newark Street, The Royal London Hospital, Whitechapel, London, England, E1 2AT, UK. \\ m.a.thaha@qmul.ac.uk.mathaha@doctors.org.uk.
}

Editorial group: Cochrane Incontinence Group.

Publication status and date: New search for studies and content updated (no change to conclusions), published in Issue 8, 2015.

Review content assessed as up-to-date: 5 February 2015.

Citation: Thaha MA, Abukar AA, Thin NN, Ramsanahie A, Knowles CH. Sacral nerve stimulation for faecal incontinence and constipation in adults. Cochrane Database of Systematic Reviews 2015, Issue 8. Art. No.: CD004464. DOI: 10.1002/14651858.CD004464.pub3.

Copyright (C) 2015 The Cochrane Collaboration. Published by John Wiley \& Sons, Ltd.

\begin{abstract}
A B S T R A C T
Background

Faecal incontinence (FI) and constipation are both socially-embarrassing and physically-disabling conditions that impair quality of life. For both, surgery may be required in a minority of people when more conservative measures fail. However, the invasiveness and irreversible nature of direct surgery on bowel and sphincter muscles, poor long-term outcomes and well-established complications makes such procedures unappealing for these benign conditions. A less-invasive surgical option to treat faecal incontinence and constipation is direct, low-voltage stimulation of the sacral nerve roots, termed sacral nerve stimulation (SNS). SNS has become the first line surgical treatment for FI in people failing conservative therapies. Its value in the treatment of constipation is less clear.
\end{abstract}

\section{Objectives}

To assess the effects of sacral nerve stimulation using implanted electrodes for the treatment of faecal incontinence and constipation in adults.

\section{Search methods}

We searched the Cochrane Incontinence Group Specialised Register, which contains trials identified from the Cochrane Central Register of Controlled Trials (CENTRAL), MEDLINE, MEDLINE In-Process, ClinicalTrials.gov, the World Health Organization (WHO) ICTRP and handsearched journals and conference proceedings (searched 5 February 2015), EMBASE (1 January 1947 to 2015 Week 5), and the reference lists of retrieved relevant articles.

\section{Selection criteria}

All randomised or quasi-randomised trials assessing the effects of SNS for faecal incontinence or constipation in adults.

\section{Data collection and analysis}

Two review authors independently screened the search results, assessed the methodological quality of the included trials, and undertook data extraction.

Sacral nerve stimulation for faecal incontinence and constipation in adults (Review)

Copyright $\Subset 2015$ The Cochrane Collaboration. Published by John Wiley \& Sons, Ltd. 


\section{Main results}

Six crossover trials and two parallel group trials were included.

Six trials assessed the effects of SNS for FI. In the parallel group trial conducted by Tjandra, 53 participants with severe FI in the SNS group experienced fewer episodes of faecal incontinence compared to the control group who received optimal medical therapy (mean difference (MD) -5.20 , 95\% confidence interval (CI) -9.15 to -1.25 at 3 months; MD $-6.30,95 \%$ CI -10.34 to -2.26 at 12 months). Adverse events were reported in a proportion of participants: pain at implant site (6\%), seroma (2\%) and excessive tingling in the vaginal region $(9 \%)$.

In the parallel group trial carried out by Thin, 15 participants with FI in the SNS group experienced fewer episodes of FI compared with the percutaneous tibial nerve stimulation (PTNS) group (MD -3.00, 95\% CI -6.61 to 0.61 at 3 months; $\mathrm{MD}-3.20$, $95 \% \mathrm{CI}$ -7.14 to 0.74 at 12 months). Adverse events were reported in three participants: mild ipsilateral leg pain during temporary testing (n $=1)$; and stimulator-site pain following insertion of neurostimulator $(\mathrm{n}=2)$.

In the crossover trial by Leroi 7 of 34 recruited participants were excluded from the crossover due mainly to complications or immediate device failure. Twenty-four of the remaining 27 participants while still blinded chose the period of stimulation they had preferred. Outcomes were reported separately for 19 participants who preferred the 'on' and five who preferred the 'off' period. For the group of 19, the median (range) episodes of faecal incontinence per week fell from 1.7 (0 to 9) during the 'off' period to 0.7 (0 to 5) during the 'on' period; for the group of five, however, the median (range) rose from 1.7 (0 to 11) during the 'off' period compared with 3.7 (0 to 11) during the 'on' period. Four of 27 participants experienced an adverse event resulting in removal of the stimulator.

In the crossover trial by Sørensen and colleagues, participants did not experience any FI episodes in either the one-week 'on' or 'off' periods.

In the crossover trial by Vaizey, participants reported an average of six, and one, episodes of faecal incontinence per week during the 'off' and 'on' periods respectively in two participants with FI. Neither study reported adverse events.

In the crossover trial by Kahlke, 14 participants with FI experienced significantly lower episodes of FI per week during the stimulator 'on' (1 (SD, 1.7)) compared with the 'off' period (8.4 (SD, 8.7)). Adverse events reported include: haematoma formation ( $\mathrm{n}=3$ ); misplacement of tined lead $(1)$; and pain at stimulator site $(n=1)$.

Two trials assessed SNS for constipation. In the Kenefick trial, the two participants experienced an average of two bowel movements per week during the 'off' crossover period, compared with five during the 'on' period. Abdominal pain and bloating occurred $79 \%$ of the time during the 'off' period compared with 33\% during the 'on' period. No adverse events occurred. In contrast, in the trial by Dinning with 59 participants, SNS did not improve frequency of bowel movements and 73 adverse events were reported, which included pain at site of the implanted pulse generator (32), wound infection (12), and urological (17) events.

\section{Authors' conclusions}

The limited evidence from the included trials suggests that SNS can improve continence in a proportion of patients with faecal incontinence. However, SNS did not improve symptoms in patients with constipation. In addition, adverse events occurred in some patients where these were reported. Rigorous high quality randomised trials are needed to allow the effects of SNS for these conditions to be assessed with more certainty.

\section{PLAIN LANGUAGESUMMARY}

\section{Sacral nerve stimulation for treating faecal incontinence and constipation in adults}

Importance of the review/Background: Faecal incontinence occurs when a person passes stools without the usual control. Constipation is harder to define but generally describes a situation in which a person feels that their bowel opening is unsatisfactory (usually a combination of difficulty or infrequency of passing stools). Both conditions can severely affect people's quality of life. There are many non-surgical treatments for both conditions but occasionally surgery is required when other options fail. Sacral nerve stimulation (SNS) is a relatively new treatment for these conditions. It involves implanting a battery-powered stimulator unit in the buttock. This is connected to electrodes which rest on the nerves in the lower spine. The stimulator then continuously sends impulses to the nerves and muscles that control the bowel and anus. Initially, a temporary electrode lead is connected to a portable battery unit outside the body. If symptoms are improved enough, this is replaced by the implanted battery.

Sacral nerve stimulation for faecal incontinence and constipation in adults (Review)

Copyright @ 2015 The Cochrane Collaboration. Published by John Wiley \& Sons, Ltd. 
Main findings: This review evaluated the published evidence for the use of SNS for patients with faecal incontinence or constipation from six trials of SNS for faecal incontinence (219 participants) and two trials of SNS for constipation (61 participants). Two of the faecal incontinence trials had a 'parallel group design', which means that one group of participants received SNS and the other control group did not receive SNS throughout the trial. The remaining six trials had a 'crossover design', in which the participants experienced equal periods with stimulation 'off' then 'on', or vice versa. The level of stimulation was such that participants could not tell whether the system was 'on' or 'off'.

SNS for faecal incontinence: In the two 'parallel group' trials, 53 and 15 participants with faecal incontinence who were in the SNS group experienced fewer episodes of faecal incontinence compared to the control group at 3 and 12 months. In the first crossover trial, 24 participants who completed the trial chose the period of stimulation they had preferred while still unaware whether this was 'on' or 'off'. Nineteen participants who preferred the 'on' period experienced 59\% fewer episodes of FI per week during the 'on' period, and 5 participants who preferred the 'off' period experienced $118 \%$ more episodes of FI per week. In the second crossover trial, the participants did not experience episodes of FI during either the 'on' or the 'off' periods. In the third trial, participants experienced $83 \%$ fewer episodes of faecal incontinence during the 'on' compared with the 'off' period. In the fourth crossover trial participants experienced $88 \%$ fewer episodes of faecal incontinence during the 'on' period compared with the 'off' period.

SNS for faecal incontinence-adverse effects: Not all trials reported adverse effects after SNS. The two 'parallel group' trials reported only minor complications, in 10\% of SNS participants in the first study, and in 3 participants in the second study. In the first crossover study 7 out of 34 participants were excluded from crossover due mainly to complications. Four out of 27 participants with an implanted system in this study experienced a problem that led to the device being removed. The participants in the fourth crossover trial experienced some complications with the SNS implanted electrode such as pain (one person), misplacement of the tined lead (one person) and haematoma (swelling containing blood) (three people).

SNS for constipation: In one trial assessing SNS for constipation, two participants reported an increase of $150 \%$ in the frequency of passing stools per week, and time with abdominal pain and swelling went down from $79 \%$ during the 'off' period to $33 \%$ during the 'on' period. However, in the much larger second trial assessing SNS for constipation, in 59 participants SNS did not improve frequency of bowel movements.

Limitations of the review: The limited evidence suggests that SNS can improve continence in some people with faecal incontinence. SNS did not improve symptoms in patients with constipation. Larger, good-quality trials are needed to provide more reliable evidence on the effectiveness of SNS for these two conditions.

\section{B A C K G R O U N D}

\section{Description of the condition}

The act of defaecation is dependent on the co-ordinated functions of the colon, rectum and anus. Considering the complexity of neuromuscular (sensory and motor) functions required to achieve planned, conscious, and effective defaecation (Scott 2011), it is no surprise that disturbances to perceived 'normal' function occur commonly at all stages of life. Clinically, such problems principally encompass presentations with faecal incontinence or constipation. Although usually described separately (as in this review), it should be noted that considerable overlap between these symptoms occurs at all ages of presentation (Burgell 2012; Rao 2004a).

\section{Faecal incontinence}

Faecal incontinence (FI) is a socially-embarrassing and physicallydisabling condition. It may be defined as the uncontrolled loss of faeces (liquid or solid) from the bowel. It may occur passively (without the person affected being aware of passing faeces); or be preceded by urgency (a sense of an urgent need to defaecate); or both, commonly termed 'mixed faecal incontinence'. A further term-'post-defaecatory seepage or leakage'-is also sometimes used to denote passive loss of small amounts of faeces retained after incomplete evacuation (Rao 2004b).

Faecal incontinence is a common problem, although the true prevalence is hard to determine due to under-reporting (Johanson 1996; NICE 2007). US population surveys suggest the prevalence of FI ranges anywhere from $2 \%$ to $17 \%$ affecting both men and women (Nelson 2004; Peery 2012; Whitehead 2009). In the UK, it is estimated that up to $10 \%$ of adults experience involuntary 
loss of solid or liquid stool causing physical, psychological and social disability; $0.5 \%$ to $1 \%$ of adults experience regular faecal incontinence that severely affects their quality of life (NICE 2007; Norton 2007). Although awareness of the health burden from faecal incontinence has increased in recent years, it still largely remains a taboo problem (Johanson 1996). Considering the higher prevalence with advancing age (Brown 2010), FI may be an even greater problem in the future. The prevalence of FI approaches $50 \%$ in nursing homes (Nelson 1998).

Faecal incontinence may result from:

- damage to the anal sphincter mechanism (either from direct trauma or damage to its nerve supply);

- age-related degeneration of the sphincter;

- spinal injury;

- other neurological causes; or

- non-sphincter causes (e.g. diarrhoea, dementia) (Lunniss 2004).

The well-documented association between FI and birth injuries has led to the belief that pudendal nerve injury or direct damage to the anal sphincter complex is the main pathophysiology (Sultan 1993; Sultan 1997a; Sultan 1997b). In truth, most FI is caused by a complex interplay of pathophysiological factors including aberrant anorectal sensation and colorectal motility, as well as structural changes or damage to the pelvic floor and sphincter complex. Indeed, women who sustain obstetric trauma often do not present with symptoms of FI until up to 30 years postpartum (Lunniss 2004; Rao 2004a).

With such aetiological and pathophysiological heterogeneity, FI remains a challenging condition to directly address by any single treatment. Conservative measures include:

- dietary modification;

- bowel retraining;

- anti-diarrhoeal medication (Ehrenpreis 2007; Omar 2013);

- biofeedback (Enck 2009; Norton 2003; Norton 2004); and

- supportive devices such as absorbent padding or plugs.

However, such measures have, at best, a lasting success in only approximately $50 \%$ of patients (Otto 2010); thus surgical treatment is often considered. The latter may include:

- bulking agents (Graf 2011);

- direct anal sphincter repair (Malouf 2000);

- artificial bowel sphincter (Altomare 2004); and

- dynamic graciloplasty (Baeten 1991).

All of these operations have well-established complications and high long-term failure rates (Altomare 2004; Malouf 2000). While several newer treatments, such as autologous muscle cell therapy, magnetic sphincter augmentation and sphincter bulking agents, are at an early clinical evaluation stage (Carr 2013; Lehur 2010; Ratto 2011), many patients may still resort to a stoma (usually colostomy) for significant intractable symptoms.

\section{Constipation}

Constipation is common in adults and children and up to $20 \%$ of the population report this symptom depending on definitions used ( $2 \%$ to $28 \%$ adults; $0.7 \%$ to $30 \%$ children) (Sonnenberg 1989 ; Stewart 1999; van den Berg 2006), with a higher prevalence in women (McCrea 2009; Mugie 2011; Sonnenberg 1989), and the elderly (Gallegos-Orozco 2012; Norton 2006). Chronic constipation (CC), usually defined as more than six months of symptoms, is less common (Probert 1995), but results in half a million UK GP consultations per annum. A proportion of the population suffer symptoms which are both chronic and more disabling (probably about $1 \%$ to $2 \%$ of the population) (Cook 2009). Such patients, who are most often female (Knowles 2003), are usually referred to secondary care with many progressing to tertiary specialist investigation. Patient dissatisfaction is high in this group: nearly $80 \%$ feel that laxative therapy is unsatisfactory (Wald 2008), and the effect of symptoms on measured QOL is significant (Irvine 2002). Chronic constipation consumes significant healthcare resources: in the US in 2012, a primary complaint of constipation was responsible for 3.2 million physician visits (Peery 2012), resulting in (direct and indirect) costs of $\$ 1.7$ billion. In the UK, it is estimated that $10 \%$ of district nursing time is spent on constipation (Poulton 1999), and the annual spend on laxatives exceeds $£ 80$ million, with $£ 17.4$ million prescribed in 2012 (HSCIC 2013).

Management of chronic constipation is a major problem due to its high prevalence and lack of widespread specialist expertise. In general, a step-wise approach is undertaken, with first-line conservative treatment such as lifestyle advice and laxatives (NHS 2012), followed by nurse-led bowel retraining programs, often including focused biofeedback (Woodward 2014), and psychosocial support. Although these treatments may improve symptoms in more than half of patients, they are very poorly standardised and are not universally successful. While some hope has been offered by a range of new prokinetic and pro-secretory drugs (Camilleri 2008; Johanson 2008), patients with intractable symptoms and impaired QOL may be offered a range of costly, irreversible surgical interventions with unpredictable results (Knowles 1999; Knowles 2009), sometimes resulting in major adverse events or a permanent stoma.

\section{Description of the intervention}

Neuromodulation is one of the fastest growing areas of medicine and may be defined as a technology that impacts upon neural interfaces to produce benefit. The concept of electrical stimulation of the pelvic floor may be traced back to the early $19^{\text {th }}$ century with several methods of direct neuromuscular stimulation developed subsequently (Hopkinson 1966). In the last 20 years, a group of treatments have been developed that employ chronic, low-voltage electrical stimulation to recruit residual function of pelvic organs by direct or indirect stimulation of the sacral spinal nerves (Matzel 1995; Matzel 1990). Such developments, which in general have 
evolved from the urology field (Brindley 1974; Tanagho 1989), have the potential to bridge the gap between conservative treatments and potentially hazardous direct surgery to the bowel or anal sphincter. An attraction of these treatments is that, unlike direct surgery to the sphincter or colon, they have the potential to modify all aspects of the co-ordinated neuromuscular functions required for defaecation (Carrington 2011), and on this basis may benefit both FI and chronic constipation. Further, neuromodulation has the intrinsic qualities of dose variation and reversibility which are rarely possible with other surgical therapies. The most established of these treatments is Sacral Nerve Stimulation (SNS). SNS involves direct, chronic, low-voltage electrical stimulation of the sacral nerve roots by the siting of an electrode via a sacral foramen (S3 is the optimal site for most patients). Whilst there has been an evolution of systems over time (MacDonagh 1990; Matzel 1990), in its most common current form SNS utilises a percutaneously-sited, commercially-manufactured quadripolar electrode lead system connected to an implanted pulse generator (InterStim ${ }^{\circledR}$ Therapy, Medtronic, Inc., Minneapolis, US) buried in the subcutaneous fat of the buttock. The Medtronic system also allows for a temporary percutaneous nerve evaluation (PNE) phase which allows the patient to trial the impact of sacral nerve stimulation on their lifestyle and test the feasibility of success before the more expensive permanent stimulator is implanted.

SNS techniques are well described in the literature, with agreement that this can be carried out effectively and safely under both general anaesthetic, and local anaesthetic with or without sedation (Mitchell 2011); with minimal reported morbidity (overall complications rates of 5\% to 26\% (Tjandra 2004)); and no reported mortality (Wong 2011).

\section{How the intervention might work}

Understanding of the mechanism of action of SNS is universally acknowledged to be an important knowledge gap limiting potential for patient selection, technology and procedural optimisation that could focus therapy, improve outcomes and reduce healthcare costs (Carrington 2014). Traditional understanding of the pathophysiology and surgical management of FI held that sphincter 'barrier' had primacy. It is now clear that whilst sphincter disruption (resulting from, for example, obstetric injuries) is still relevant to the development of FI, it is only one factor in complex defaecatory dysfunction that involves alteration in unconscious anorectal and pelvic reflexes and conscious modulation by the central nervous system.

The importance of sensory dysfunction on both urinary and bowel control is being increasingly appreciated and there is strong evolving evidence (in man (Knowles 2012); and experimental animals (Evers 2014; Griffin 2011)) that the mechanism of action of SNS results primarily from modulation of afferent nerve activity rather than motor effects on the anal sphincter itself (Carrington 2014; Duelund-Jakobsen 2013; Patton 2013). The effects of SNS on colonic motor activity have also been studied. Data suggest that SNS, but not sham stimulation, increased the frequency of retrograde propagated sequences throughout the colon in participants with FI (Patton 2013) i.e. effects anticipated to delay colonic transit. In contrast SNS also increased colonic propagating sequences in participants with slow-transit constipation (Dinning 2012). This disparity of effect may reflect baseline differences of colonic motor activity, however further study is required to explain these seemingly counter-intuitive findings.

\section{Why it is important to do this review}

SNS is now considered the first-line surgical intervention for people with FI for whom conservative treatments have failed (NICE 2007). Over 100 published case series (of over 2000 participants), including some quite large prospective studies (Melenhorst 2007; Wexner 2010), attest to the general success of this approach, and SNS has regulatory approval in most major health systems (NHS 2013; NICE 2007). Recent systematic review data show favourable mid-and long-term positive outcomes for SNS of approximately $80 \%$ based on a greater than $50 \%$ reduction in FI episodes, although this figure is reduced to approximately $60 \%$ when results are reanalysed using all available participants who start therapy as the denominator (comparable with intention-totreat principles) (Thin 2013).

In comparison with FI, the role of SNS in treating chronic constipation is less well established. However, it carries the same attractions: namely the avoidance of potentially hazardous direct surgery to the colon or pelvic floor. Unfortunately, favourable results of a European experience of SNS on 62 participants (63\% successful) with chronic constipation, (of mixed or specific pathophysiology (Kamm 2010 and Knowles 2012 respectively)) have not been replicated by others (Holzer 2008; Maeda 2010; Vitton 2009). On this basis SNS has not yet, in general, been commissioned as a treatment for constipation in most health systems.

Despite the implicit advantages and reported success of SNS over the last 20 years (especially for FI), one major drawback remains: the initial costs of SNS are still considerable both in terms of direct equipment cost and indirect hospital admission costs (Dudding 2008). On this basis, health practitioners need to be reassured of the efficacy of SNS therapy. This systematic review updates the available evidence from randomised controlled trials.

\section{O B JE C T IVES}

To assess the effects of sacral nerve stimulation using implanted electrodes for the treatment of faecal incontinence and constipation in adults.

The following comparisons were made: 
1. Sacral nerve stimulation (implanted) versus control or sham stimulation

2. Sacral nerve stimulation (implanted) versus another active treatment

\section{METHODS}

\section{Criteria for considering studies for this review}

\section{Types of studies}

We included randomised, quasi-randomised and crossover trials. Crossover trials have been identified with the suffix '\#'.

\section{Types of participants}

Adults with faecal incontinence or constipation, including functional, structural and neurological causes.

\section{Types of interventions}

One arm of the trial had to use a surgically implanted device to provide sacral nerve stimulation.

Comparators considered included:

1. mock, sham or placebo treatment; and

2. any alternative active intervention considered appropriate by the trialists, such as dynamic graciloplasty, artificial bowel sphincter implants, stoma formation, absorbent pads, anal plugs, and physical or behavioural therapies.

Trials in which both arms used active implanted sacral nerve stimulation were not included in this review. Newer treatment modalities including magnetic and transcutaneous stimulation were considered.

\section{Types of outcome measures}

\section{Primary outcomes}

\section{Faecal incontinence}

The primary outcomes were: (a) cure or improvement of incontinence; and (b) quality of life. Outcomes were considered in the following categories:

(1) Faecal incontinence (number cured or improved, episodes of faecal incontinence, urgency, ability to defer defaecation, use of pads, use of anal plugs, incontinence score, and need for further treatment such as medication or surgery).

(2) Quality of life (generic and condition-specific).

\section{Constipation}

The primary outcomes were: (a) cure or improvement of constipation; and (b) quality of life. Outcomes were considered in the following categories:

(1) Constipation (number cured or improved, frequency of bowel movements, abdominal pain/bloating, constipation score, and need for further treatment such as medication or surgery).

(2) Quality of life (generic and condition-specific).

\section{Secondary outcomes}

\section{Faecal incontinence}

Outcomes were considered in the following categories:

(1) Surrogate measures, such as anorectal manometry (resting pressure, maximum squeeze pressure, rectal sensory threshold to balloon distention, sensation of urgency to balloon distention, and maximum tolerated rectal volume to balloon distention).

(2) Adverse effects (infection or pain or both at the implantation site; displacement of the electrodes; technical failure requiring removal or change in urinary function, or both).

(3) Health economics (costs, resource implications and cost-effectiveness or cost utility evaluation).

(4) Other outcomes (other outcome measures quoted by trial authors and judged to be important by the authors of this review).

\section{Constipation}

Outcomes were considered in the following categories:

(1) Surrogate measures, such as anorectal manometry (resting pressure, maximum squeeze pressure, rectal sensory threshold to balloon distention, sensation of urgency to balloon distention, and maximum tolerated rectal volume to balloon distention).

(2) Adverse effects (infection or pain or both at the implantation site; displacement of the electrodes; technical failure requiring removal or change in urinary function, or both).

(3) Health economics (costs, resource implications, and cost-effectiveness or cost utility evaluation).

(4) Other outcomes (other outcome measures quoted by trial authors and judged to be important by the authors of this review).

\section{Search methods for identification of studies}

We did not impose any language or other limitations on the searches described below.

\section{Electronic searches}

This review drew on the search strategy developed for the Incontinence Group as a whole. Relevant trials were identified from the Cochrane Incontinence Group Specialised Trials Register. The 
methods used to derive this, including the search strategy, are described under the Group's module in the Cochrane Library. The register contains trials identified from the Cochrane Central Register of Controlled Trials (CENTRAL), MEDLINE, MEDLINE In-Process, ClinicalTrials.gov, WHO ICTRP and hand searching of journals and conference proceedings.

The Incontinence Group Specialised Register was searched using the Group's own keyword system; the search terms used are given in Appendix 1.

Date of the most recent search of the register for this review: 5 February 2015.

The majority of the trials in the Incontinence Group's Specialised Register are also contained in CENTRAL.

Also Embase (1 January 1947 to 2015 Week 5) was searched on 5 February 2015 using the search strategy given in Appendix 2. Only the years 2010 to 2015 (inclusive) were searched as these years were not covered by the Cochrane Collaboration's centralised search of Embase for CENTRAL at this time.

\section{Searching other resources}

All reference lists of identified trials were searched.

\section{Data collection and analysis}

Analyses of crossover trials were based on data available from included relevant trials. Meta-analysis could not be performed because of variation in reported outcomes.

\section{Selection of studies}

Two review authors (AA, MAT) independently evaluated reports of all potentially eligible studies for inclusion. Any disagreements were resolved by discussion or arbitration by the review group at consensus meetings.

\section{Data extraction and management}

Two review authors (AA, MAT) independently undertook data extraction for the five new trials that were added (Dinning 2015\#; Kahlke 2015\#; Sørensen 2010\#; Thin 2015; Tjandra 2008); and checked and updated the information from the previously included trials, in particular 'Risk of bias' assessment. We planned to seek clarification from the trialists where data were collected but not reported, or reported in a form unsuitable for the review. Included data were processed as described in the Cochrane Handbook for Systematic Reviews of Interventions (http://www.cochrane.org/ resources/handbook/hbook.htm) (Higgins 2011). Any disagreements were resolved by discussion or arbitration by the review authors. Data from crossover were entered into Other Data Tables.

\section{Assessment of risk of bias in included studies}

Two review authors (AA, MAT) independently assessed the methodological quality of all the included trials using the Cochrane Incontinence Group's assessment criteria. Studies were not excluded from the review on the basis of methodological quality. Any disagreements were resolved by discussion or arbitration by all the review authors.

\section{Measures of treatment effect}

We planned to combine data, if this was considered appropriate, by applying fixed-effect methods, with relative risk used for dichotomous outcomes and weighted mean difference used for continuous outcomes.

\section{Dealing with missing data}

We sought clarification on missing data from the trialists and, when available, they were included in the final abstraction and analysis.

\section{Assessment of heterogeneity}

If visual inspection or the $\mathrm{Chi}^{2}$ test had suggested heterogeneity at the $10 \%$ level then we planned to explore the reasons for this. If the level of heterogeneity was serious enough to affect the validity of the results then applying a random-effects method would be considered. Alternatively, if it was considered inappropriate to combine data from the included trials we planned instead to present a narrative synthesis of the results of the primary studies. In the event it was not possible to find any data suitable for meta-analyses, and all the data are presented in 'Other Data' tables.

\section{Assessment of reporting biases}

All included trials were formally assessed for methodological quality, including for selective reporting using appropriate tools in Cochrane's Review Manager (RevMan) software. The methodological quality of included trials are reported in 'Risk of bias' figure and summary.

\section{Data synthesis}

We planned to combine data by applying fixed-effect methods when appropriate.

\section{Subgroup analysis and investigation of heterogeneity}

If the evidence had allowed, we planned to undertake sub-group analysis on the following categories of participants:

(1) participants with faecal urgency;

(2) participants with structural defects of the anal sphincter; 
(3) participants with partial spinal cord injury; and

(4) participants with central neurological disease.

\section{Sensitivity analysis}

We planned to use sensitivity analysis to test the effects of included studies of poor methodological quality, if appropriate.

RES U L T S

\section{Description of studies}

Sacral nerve stimulation for faecal incontinence and constipation in adults (Review)

Copyright ( 2015 The Cochrane Collaboration. Published by John Wiley \& Sons, Ltd.
Please see 'Characteristics of included studies' and 'Characteristics of excluded studies' tables for further details.

\section{Results of the search}

A total of 197 records, identified by the literature search, were screened and 16 full-text articles of potentially eligible studies were obtained. There were 10 reports of 8 included studies and 3 reports of 3 excluded studies. Additionally there were three reports of three ongoing studies, details of which can be found in the Characteristics of ongoing studies table. Figure 1 illustrates the process of the literature search and selection of studies for the update of this review. 
Figure I. PRISMA flow diagram

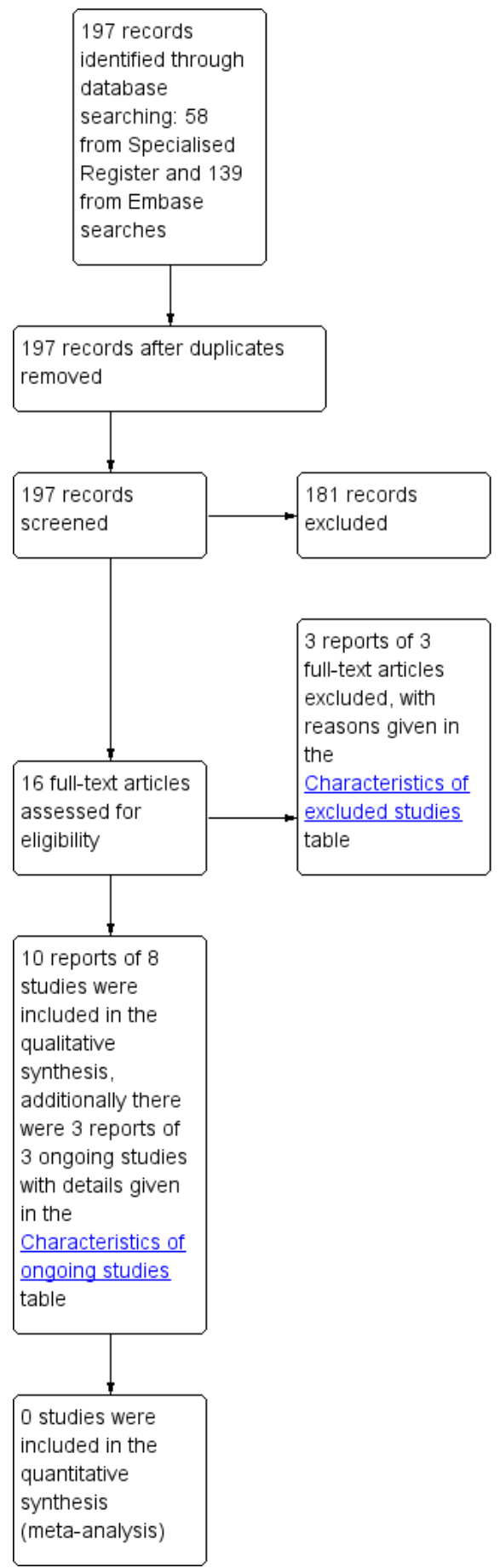

Sacral nerve stimulation for faecal incontinence and constipation in adults (Review) 


\section{Included studies}

Eight potentially relevant trials identified by the search strategy were included (Dinning 2015\#; Kahlke 2015\#; Kenefick 2002\#; Leroi 2005\#; Sørensen 2010\#; Thin 2015; Tjandra 2008; Vaizey 2000\#).

Six trials assessed the effects of sacral nerve stimulation (SNS) for faecal incontinence (Kahlke 2015\#; Leroi 2005\#; Sørensen 2010\#; Thin 2015; Tjandra 2008; Vaizey 2000\#).

Two trials assessed the effects of SNS for constipation (Dinning 2015\#; Kenefick 2002\#).

\section{Design}

Six trials had a crossover design (Dinning 2015\#; Kahlke 2015\#; Kenefick 2002\#; Leroi 2005\#; Sørensen 2010\#; Vaizey 2000\#), while two had a parallel-group design (Thin 2015; Tjandra 2008). In the study carried out by Thin 2015 patients were allocated to receive either SNS or percutaneous tibial nerve stimulation (PTNS). In the SNS group participants underwent a trial with temporary SNS for two weeks; those who exhibited a good response (at least $50 \%$ reduction in FI) had permanent SNS implantation. In the trial conducted by Tjandra 2008 all participants attended multidisciplinary pelvic floor clinic and were randomised to sacral nerve stimulation (SNS group) or optimal medical therapy (control group). In the SNS group all participants were tested for a minimum of seven days and participants who exhibited a good response underwent permanent implantation with a quadripolar electrode for the 12 months of follow up. The electrode combination with best perception of muscle contraction of perineum and anal sphincter with least voltage was selected for permanent stimulation.

Moreover, in the trials conducted by Kenefick 2002\# and Vaizey 2000\#, participants underwent two two-week intervals with subsensory stimulation either 'on' or 'off'. There was no interval between the treatment periods.

Similarly, in the trial conducted by Sørensen 2010\#, participants underwent two one-week intervals with stimulation either 'on' or 'off'. There was no interval between the treatment periods.

In the trial carried out by Dinning 2015\#, participants underwent three weeks of temporary peripheral nerve stimulation, then all patients underwent permanent SNS electrode implantation. Participants were then randomised to receive subsensory stimulation or sham for three weeks; and after a two-week washout period the group that received sham stimulation now received subsensory stimulation for three weeks and vice versa. Then, following a further two-week washout period, participants were re-randomised to receive either sham or suprasensory stimulation for three weeks. Participants then underwent a further two-week washout period, after which participants who received sham stimulation now underwent suprasensory stimulation for three weeks and vice versa. In the trial conducted by Kahlke 2015\#, after permanent implantation 31 patients had a minimum of 3 months with the stimulator turned on. Then participants were invited to take part in the crossover study. Sixteen participants were enrolled, who were subsequently randomised in a crossover design to 'on' or 'off' stimulation, each period lasting three weeks. At the end of each threeweek period the stimulator was programmed to the opposite mode ('off' or 'on'). While still blinded at the end of the crossover period participants selected the period of stimulation they had preferred ('off' or 'on'). The mode of stimulation corresponding to the preferred period ('off' or 'on') was continued for a further three months.

In the trial conducted by Leroi 2005\#, after definitive 'permanent' implantation each participants had a one- to three-month phase when the stimulator was turned 'on' (postimplantation period), to optimise the effectiveness of stimulation by determining the most effective parameters of stimulation (choice of stimulation electrodes and intensity of stimulation). At the end of the postimplantation period, participants were randomised in a crossover design to 'on' or 'off' stimulation for a two-month period. At the end of the first month, the neurostimulator was programmed to the opposite mode ('off' or 'on'), and monitoring continued for a second month. There was no interval between the two treatment periods. At the end of the crossover period, while still blinded, the participants chose the period of stimulation ('on' or 'off') they had preferred. The mode of stimulation corresponding to the selected period ('on' or 'off') was then continued for a three-month followup period. If the participant could not choose between one of the two periods, the stimulator was turned 'on'.

\section{Sample sizes}

In total the trials enrolled 280 people, of whom 177 received a definitive implant. The trials included:

\section{Faecal incontinence:}

- Vaizey 2000\# included two participants;

- Kahlke 2015\# enrolled 16 participants, all received a permanent SNS implant;

- Leroi 2005\# enrolled 34 participants, of whom 27 went on to receive a permanent implant;

- Sørensen 2010\# enrolled 7 participants;

- Thin 2015 enrolled 40 participants, of whom 16 received a permanent SNS implant;

- Tjandra 2008 enrolled 120 participants, of whom 53 received a permanent implant. 


\section{Constipation}

- Dinning 2015\# enrolled 59 participants of whom 55 had permanent implant; and

- Kenefick 2002\# included two participants;

\section{Setting}

Two trials were carried out in the same hospital centre (St. Mark's Hospital, Harrow); neither reported the time period during which the trial was undertaken (Kenefick 2002\#; Vaizey 2000\#). The third trial was carried out in a single centre located in Germany (Kahlke 2015\#). The fourth trial was a multicentre trial (number of centres not stated), set in France, which took place during the period February 2000 to February 2003 (Leroi 2005\#). The fifth trial was a single-centre trial set in Denmark (Sørensen 2010\#). The sixth trial was a two-centre trial set in two London hospitals (Royal London Hospital and University College London Hospital, UK) (Thin 2015). The seventh trial was a single-centre trial set in Australia (Tjandra 2008). The eighth trial was a two-centre trial conducted in Australia (Dinning 2015\#).

\section{Participants}

Of 280 participants enrolled, 246 (87.9\%) were women.

\section{Compliance and treatment received}

In the trial carried out by Thin and colleagues, 8 of the 23 participants in the SNS group did not receive permanent implantation (Thin 2015). The reasons cited include: intercurrent illness requiring urgent medical management $(\mathrm{n}=1)$; symptoms resolved $(\mathrm{n}=1)$; declined further participation $(\mathrm{n}=2)$; failed temporary SNS ( $n=3$ ); withdrawn from treatment for urgent investigation of a new pararectal cyst $(n=1)$. In the trial conducted by Tjandra and colleagues 7 of the 60 participants in the SNS arm did not receive permanent implantation (Tjandra 2008). The reasons were: cannulation of foramen with electrode was not achieved due to previous back surgery, which required bone graft from the sacral area $(\mathrm{n}=1)$; insufficient therapeutic response with peripheral nerve evaluation $(n=5)$; and concern participants might require magnetic resonance imaging of brain post excision of meningioma ( $\mathrm{n}$ $=1$ ).

In the trial carried out by Kahlke 2015\#, out of the 16 participants enrolled, 2 discontinued; the reasons were (i) participant turned stimulator 'on' with handheld device because she had become completely incontinent $(\mathrm{n}=1)$; (ii) participant fell on lower back leading to breakage of permanent lead $(n=1)$.

In the trial conducted by Leroi $2005 \# 10$ of 34 participants prematurely discontinued the trial. The reasons for discontinuation were: device-related adverse events $(\mathrm{n}=4)$; protocol violation $(\mathrm{n}=$ $3)$; insufficient therapeutic response $(n=1)$; no return to followup $(\mathrm{n}=1)$; and adverse event (stroke) not related to SNS $(\mathrm{n}=1)$.
In the trial conducted by Dinning 2015\# four participants did not receive permanent SNS implant due to depression $(n=1)$; too far to travel $(\mathrm{n}=2)$; and could not commit $(\mathrm{n}=1)$. Of those who received permanent implant 2 participants discontinued the study due to pregnancy $(n=1)$; and severe wound infection $(n=1)$.

\section{Age}

The age of both participants in the trial conducted by Kenefick 2002\# was 36 years, while in the trial conducted by Vaizey 2000\# the participants were aged 65 and 61 years. The mean age of the participants in the trial carried out by Kahlke 2015\# was 55.5 years (standard deviation $(\mathrm{SD})=11.8)$. The median age of the participants in the trial conducted by Leroi 2005\# was 57 years (range 33 to 73 years). In the trial conducted by Sørensen 2010\# the median age of participants was 67 years (range 60 to 87 years). In the trial conducted by Thin 2015 the mean age of participants was 59 years (SD = 13 in the SNS group and 11 in the PTNS group). In the trial conducted by Tjandra 2008 the median age of the participants was 63.9 years $(\mathrm{SD}=13.2)$ in the SNS arm and 63 years $(\mathrm{SD}=12.1)$ in the control group. In the trial conducted by Dinning 2015\# the median age was 42 years (range 19 to 74 years).

\section{Cause/type of faecal incontinence or constipation}

The causes of faecal incontinence in the two participants in Vaizey's trial were, respectively, scleroderma and idiopathic degeneration of the internal anal sphincter (Vaizey 2000\#). The cause of faecal incontinence cited in the trial conducted by Kahlke 2015\# were idiopathic $(n=8)$, anorectal surgery $(n=4)$, and neurogenic $(n=$ 4). In the trial conducted by Leroi $2005 \#$ the majority of participants $(22$ of $34,65 \%)$ suffered from urge incontinence, while four suffered from passive incontinence and eight from mixed incontinence. The causes of incontinence were reported as idiopathic (n =18); pudendal neuropathy $(\mathrm{n}=14)$; postoperative internal anal sphincter fragmentation $(\mathrm{n}=1)$; and primary internal anal sphincter degeneration $(n=1)$ (Leroi 2005\#). In the trial conducted by Thin 2015 participants suffered from urge and passive incontinence. In the trial conducted by Tjandra 2008 all participants had both passive and urge incontinence. The participants in the trial conducted by Kenefick 2002\# suffered from severe resistant idiopathic constipation that had failed maximal conservative treatment. The participants in the trial conducted by Dinning 2015\# suffered severe refractory idiopathic slow transit constipation. The cause of faecal incontinence in the trial conducted by Sørensen 2010\# was not stated. (See 'Characteristics of included studies' table for details of the inclusion/exclusion criteria applied by each trial).

\section{Interventions}


The intervention in all eight trials consisted of SNS via a permanently-implanted stimulator (Medtronic InterStim ${ }^{\circledR}$ ).

In the trials conducted by Kenefick 2002\#, Sørensen 2010\#, and Vaizey 2000\#, the participants had received permanent implants respectively 12 months, 12 months and 9 months previously.

- Kenefick 2002\# reported that prior to permanent implantation, both participants had undergone a successful three-week trial of temporary percutaneous stimulation; whereas Thin 2015, Tjandra 2008, and Leroi 2005\# reported that before permanent implantation, participants underwent temporary percutaneous stimulation for, on average, 14 days, 10 days and between 8 and 15 days respectively to assess their response to treatment.

- Similarly, Kahlke 2015\# reported that before permanent implantation, participants underwent temporary percutaneous stimulation for a period between 14 and 20 days to assess their response to treatment.

- In the trial conducted by Dinning 2015\#, following 3 weeks of temporary peripheral nerve evaluation all participants underwent permanent SNS electrode implantation.

- In the trial conducted by Thin 2015, participants underwent a trial of temporary SNS and participants with a good response (at least $50 \%$ reduction in episodes of FI) progressed to permanent stimulation.

- Also, in the trial conducted by Leroi 2005\#, the decision to progress from temporary to permanent stimulation was made on the basis of at least a $50 \%$ reduction in the number of episodes of incontinence per week, or a $50 \%$ reduction in the number of faecal urgency episodes per week, or both.

- Similarly, in the trial conducted by Tjandra 2008 the decision to progress to permanent stimulation was based on a good response, defined as a $50 \%$ or greater reduction in faecal incontinence episodes per week or a $50 \%$ or greater reduction in number of days with faecal incontinence per week.

In the trial conducted by Kahlke 2015\# and Leroi 2005\# the permanent pulse generator was placed in the upper outer part of the buttocks. Similarly, in the trial conducted by Dinning 2015\# and Tjandra 2008 the permanent pulse generator was placed in the gluteal area. In the trial conducted by Vaizey 2000\# it was placed in the abdominal wall. Kenefick 2002\# and Sørensen 2010\# did not report the location of the pulse generator.

\section{Duration of treatment and follow up}

The length of time between the participants receiving a permanently-implanted stimulator and the start of the crossover period varied from 3 weeks (Dinning 2015\#), around 3 months (Kahlke 2015\#; Leroi 2005\#), through 9 months (Vaizey 2000\#), to 12 months (Kenefick 2002\#). In the trial carried out by Thin 2015 the follow-up time for the SNS and PTNS groups was six months. In the trial conducted by Tjandra 2008, the follow up time for the SNS group and the control group was 12 months.
In two trials the crossover period consisted of two two-week periods when the stimulator was either 'on' or 'off', with no followup (Kenefick 2002\#; Vaizey 2000\#). Similarly, in the third trial the crossover period consisted of two one-week periods when the stimulator was either 'on' or 'off' with no follow-up (Sørensen 2010\#); while in the fourth, larger, trial the crossover period consisted of two one-month periods when the stimulator was 'on' or 'off', with a three-month follow-up (Leroi 2005\#). In the fifth trial (Kahlke 2015\#), the crossover period consisted of two three-week periods when the stimulator was 'off' or 'on', with a three-month follow-up. In the sixth trial (Dinning 2015\#), the crossover period consisted, in the suprasensory phase, of two three-week periods where the stimulator was on (suprasensory) or off (sham); longterm follow-up is still ongoing.

\section{Outcomes}

The trials reported a variety of outcome measures.

Vaizey 2000\# reported that participants used a diary to record episodes of faecal incontinence for liquid or solid stool; anal manometry was undertaken; and health status was assessed both before permanent implantation and again at the beginning of the trial, using an SF-36 questionnaire. In terms of anal manometry, a stationary pull-through method was used with an eight-channel perfused system, and the squeeze pressure was measured as the incremental rise. Rectal sensation was tested using balloon distension with air (Vaizey 2000\#).

Leroi 2005\# reported that participants also used a diary, recording episodes of faecal incontinence, faecal urgency, delay in postponing defaecation, and bowel movements. Severity of incontinence was graded by the Cleveland Clinic Incontinence Scoring System, while quality of life was assessed with the French version of the American Society of Colon and Rectal Surgeons' (ASCRS) Fecal Incontinence Quality of Life Scale (FIQL). Anal manometry was also undertaken (Leroi 2005\#). Measurements of maximum resting pressure and maximum squeeze pressure were recorded at baseline, at the end of each crossover period, and at follow-up; while rectal sensation to balloon distension with air was recorded at baseline and at the end of the follow-up period (Leroi 2005\#). Kahlke 2015\# reported outcomes that included frequency of bowel movements, frequency of faecal incontinence, and the Cleveland Clinic Incontinence Score (CCIS).

In the trial conducted by Dinning 2015\# participants used a bowel diary (stool frequency per week; bowel motion per week; feeling of complete evacuation per week; straining per week; laxative-free days per week; soft stool per week; normal stool per week; hard stool per week; pain score weekly average; bloating score weekly average; weekly global satisfaction score; weekly bothersome score). Quality of life was documented using the SF-36 questionnaire.

Also, in the trial conducted by Thin 2015 participants utilised a bowel diary to document the number and type of incontinence episodes per week. Additionally, symptom severity was assessed 
through the use of Cleveland Clinic Incontinence Score and quality of life was measured through use of Faecal Incontinence Quality of Life Scale (FIQL), Short Form 36 (SF-36) and EQ-5D.

Similarly, in the trial conducted by Tjandra 2008 participants used a bowel diary to record the number of incontinent episodes per week; days with incontinence per week; days with staining per week; and days with pads per week. Severity was scored by the Wexner incontinence score (Cleveland Clinic Incontinence Scoring System); and quality of life was evaluated by ASCRS's FIQL, and the standard Short Form-12 health survey quality of life questionnaire (SF-12) (Tjandra 2008). Measurements of anal manometry (resting and squeeze pressure) were undertaken at baseline for both SNS and control group, while further anal manometry measurements were only carried out for the SNS group during peripheral nerve evaluation and at 3-, 6- and 12-month follow-up (Tjandra 2008).

In the trial conducted by Sørensen 2010\#, outcomes were reported using bowel diaries and anal manometry.

In the trial conducted by Kenefick 2002\#, outcomes included diary-recorded bowel movements; the Wexner Constipation Score; a symptom analogue score; anal manometry; and quality of life. In terms of anal manometry, resting pressure was the maximal anal resting pressure using a stationary pull-through technique, and squeeze pressure was the maximal increment above resting pressure. Threshold, urge and maximal tolerated volume were to rectal balloon distension with air. Anal and rectal electrosensation measured threshold sensation with increasing amplitude of stimulation, recorded with a $1 \mathrm{~cm}$ bipolar ring electrode $(5 \mathrm{~Hz}, 0.1 \mathrm{~ms}$ and $10 \mathrm{~Hz}, 0.5 \mathrm{~ms}$ respectively) (Kenefick 2002\#).

\section{Timing of outcome measures}

Four trials reported results at the end of the crossover period (Dinning 2015\#; Kenefick 2002\#; Sørensen 2010\#; Vaizey 2000\#), while the trials by Kahlke 2015\# and Leroi 2005\# also reported results at the end of a three-month follow-up after the crossover period ended. The trial by Thin 2015 reported results at baseline prior to intervention, at 3 months and 6 months follow up. Tjandra 2008 reported results at the end of a 12-month follow-up.

\section{Excluded studies}

See 'Characteristics of excluded studies' table.

\section{Risk of bias in included studies}

The results of the methodological quality assessment along with justifications are covered in the 'Risk of bias' tables (see 'Characteristics of included studies' table) for each trial and are illustrated in Figure 2 and Figure 3. 
Figure 2. Risk of bias summary: review authors' judgements about each risk of bias item for each included study.

\begin{tabular}{|c|c|c|c|c|c|c|c|}
\hline & 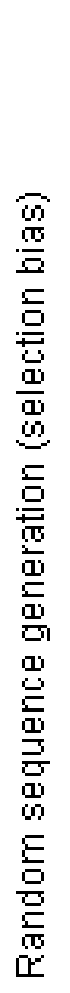 & 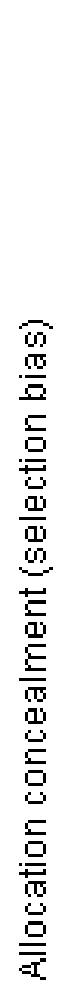 & 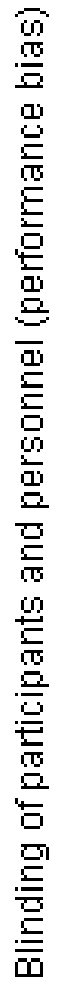 & 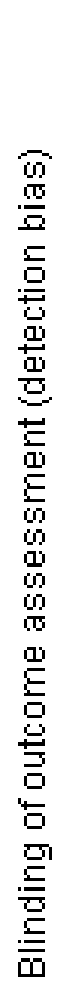 & 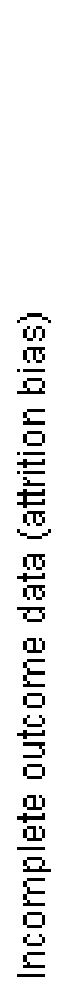 & 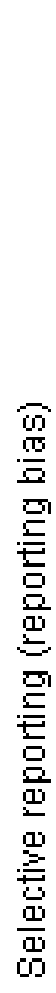 & 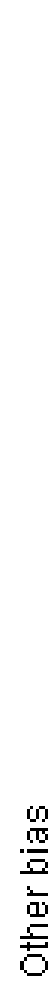 \\
\hline \multicolumn{8}{|l|}{ Dinning 2015\# } \\
\hline Kahlke 2015\# & + & $?$ & 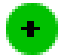 & + & $?$ & + & \\
\hline Kenefick 2002\# & $?$ & $?$ & 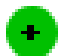 & + & + & $?$ & \\
\hline Leroi 2005\# & + & $?$ & + & + & $?$ & + & \\
\hline Sørensen $2010 \#$ & $?$ & $?$ & a & + & + & ? & \\
\hline Thin 2015 & + & 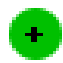 & $?$ & $?$ & $?$ & + & \\
\hline Tjandra 2008 & $?$ & + & & & $?$ & + & \\
\hline Vaizey 2000\# & $?$ & ? & + & + & + & ? & + \\
\hline
\end{tabular}


Figure 3. Risk of bias graph: review authors' judgements about each risk of bias item presented as percentages across all included studies.

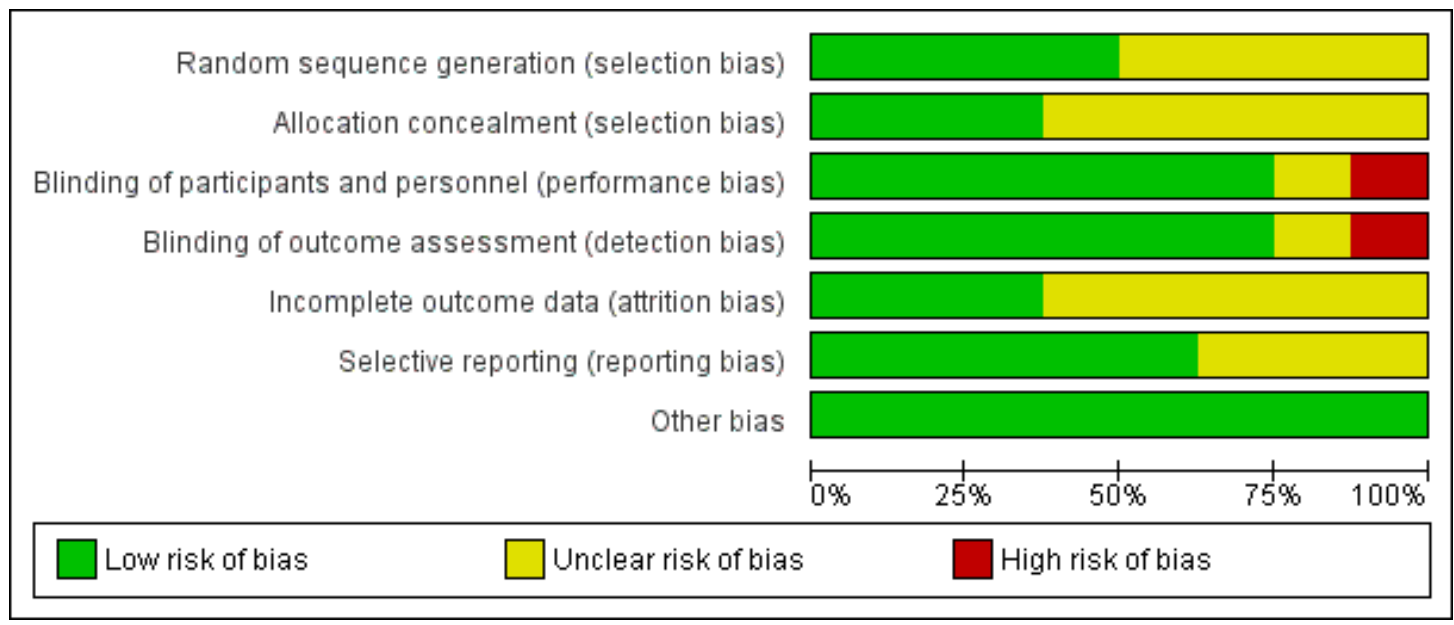

\section{Allocation}

The information is provided in the 'Characteristics of included studies' table and presented visually in Figure 2 and Figure 3.

\section{Random number generation}

The method of randomisation was unclear in the trial conducted by Tjandra 2008. Thin 2015 randomised patients remotely using a statistician uninvolved in recruitment: requests were made by and actioned by email. Dinning 2015\# utilised an off-site (NHMRC) clinical trials centre automated phone link. Leroi 2005\# and Kahlke 2015\# randomised participants by using a random numbers table. Similarly, Sørensen 2010\# randomised participants using shuffling of envelopes but did not indicate how the envelopes were filled. Kenefick 2002\# and Vaizey 2000\# provided no details of the method for deciding which participants were initially allocated to stimulator 'off' or 'on'.

\section{Concealment of allocation}

Five of the trials did not explicitly state that allocation was concealed (Kahlke 2015\#; Kenefick 2002\#; Leroi 2005\#; Sørensen 2010\#; Vaizey 2000\#). In the trial by Thin 2015 and Dinning 2015\# randomisation and allocation was made remotely, hence low risk of bias. The Tjandra 2008 trial, which used sealed envelopes, reported that the quality of allocation concealment was at low risk of bias.

\section{Blinding}

In the trial carried out by Thin 2015, the outcome assessor was blinded to participant allocation. The participants and the outcome assessor were not blinded to the allocation in the trial conducted by Tjandra 2008. In the remaining six trials the participants and outcome assessors were blinded to the allocation (Dinning 2015\#; Kahlke 2015\#; Kenefick 2002\#; Leroi 2005\#; Sørensen 2010\#; Vaizey 2000\#).

\section{Incomplete outcome data}

There were no withdrawals in three trials (Kenefick 2002\#; Sørensen 2010\#; Vaizey 2000\#). However, in the trial conducted by Thin 2015, 9 participants out of the 40 enrolled withdrew from the trial. Likewise, in the trial carried out by Leroi 2005\#, 10 people out of the 34 enrolled prematurely discontinued the trial. Furthermore, in the trial conducted by Kahlke 2015\#, 2 participants out of the 16 enrolled discontinued the trial. Similarly, in the trial conducted by Tjandra 2008 seven participants in the SNS group prematurely discontinued. In the trials conducted by Kenefick 2002\# and Vaizey 2000\#, most of the outcome results were reported for everyone who entered the trials. As the participants were analysed in the groups to which they were originally allocated, the analysis was effectively intention-to-treat. In the trial carried out by Dinning 2015\#, out of the 59 participants enrolled, 6 withdrew. The reasons for discontinuation were depression $(\mathrm{n}=$ 
1), too far to travel $(n=2)$, could not commit $(n=1)$, pregnancy $(\mathrm{n}=1)$ and severe wound infection $(\mathrm{n}=1)$.

\section{Selective reporting}

Five trials were at low risk of bias as they reported all outcomes for everyone (Dinning 2015\#; Kahlke 2015\#; Leroi 2005\#; Tjandra 2008; Thin 2015); the others trials were unclear (see 'Risk of bias' tables Figure 2; Figure 3).

\section{Other potential sources of bias}

None of the trials reported other sources of bias and so were judged to be at low risk on this domain.

\section{Effects of interventions}

The eight trials, which comprised two parallel group trials (Thin 2015 and Tjandra 2008) and six crossover trials (Dinning 2015\#, Kahlke 2015\#, Kenefick 2002\#, Leroi 2005\#, Sørensen 2010\#, and Vaizey 2000\#), included 280 participants, of whom 177 received a permanently-implanted stimulator.

\section{Faecal incontinence}

Six of these trials investigated the effects of SNS for faecal incontinence (Kahlke 2015\#; Leroi 2005\#; Sørensen 2010\#; Thin 2015; Tjandra 2008; Vaizey 2000\#).

I. Clinical outcomes (number cured and improved, episodes of faecal incontinence, ability to defer defaecation, urgency, incontinence score)

\section{SNS versus control (medical therapy)}

In the trial by Tjandra 2008 the SNS group experienced fewer episodes of faecal incontinence compared to the control group who received optimal medical therapy

- both at 3 months (MD $-5.20,95 \% \mathrm{CI}-9.15$ to -1.25 , Analysis 1.1.1)

- and 12 months (MD $-6.30,95 \% \mathrm{CI}-10.34$ to -2.26 , Analysis 1.1.2),

In addition, SNS was better than control in terms of:

- Number of days of pad use per week (MD - 1.40, 95\% CI

-2.59 to -0.21 at 3 months, Analysis 1.2.1; though this was no longer statistically significant at 12 months, MD -1, 95\% CI

-2.13 to 0.13 , Analysis 1.2.2);

- Cleveland Clinic Incontinence Score (MD -11, 95\% CI -11.60 to -10.40 at 3 months; and MD -12.90 to -13.58 to -12.22, Analysis 1.5).
Additionally, none of the participants in the SNS group had worsening of faecal incontinence, with 25 participants (47.2\%) achieving continence, but the data for the control group were not reported (Tjandra 2008).

\section{SNS versus PTNS}

In the trial carried out by Thin 2015 the SNS group experienced fewer episodes of faecal incontinence compared to the PTNS group:

- both at 3 months (MD $-3.00,95 \% \mathrm{CI}-6.61$ to 0.61 , Analysis 2.1.1)

- and 6 months (MD $-3.20,95 \% \mathrm{CI}-7.14$ to 0.74 , Analysis 2.1.2).

Additionally, SNS was better than PTNS with regards to Cleveland Clinic Incontinence Score:

- both at 3 months (MD $-1.70,95 \%$ CI -5.14 to 1.74 , Analysis 2.2.1)

- and 6 months (MD $-3.00,95 \% \mathrm{CI}-6.74$ to 0.74 , Analysis 2.2.2).

Additionally, at the six months follow-up three participants in the SNS group and PTNS group reported no episodes of faecal incontinence. Moreover, in the SNS group 10 participants had a 50\% or greater reduction in episodes of faecal incontinence compared with 7 participants in the PTNS group (Thin 2015).

\section{Faecal incontinence: crossover trials}

In the trial conducted by Vaizey 2000\#, during the period when the stimulator was 'off' the participants experienced an average of six episodes of faecal incontinence per week, compared with an average of one episode per week when the stimulator was 'on' (Analysis 3.2). SNS resulted in one participant being cured and the other experiencing a reduction in the number of episodes of faecal incontinence per week from 10 when the stimulator was 'off' to one when it was 'on' (Analysis 3.1).

In the trial conducted by Leroi 2005\#, at the end of the crossover period and while still blinded, the participants chose the period of stimulation ('on' or 'off') they had preferred and the mode of stimulation corresponding to the selected period ('on' or 'off') was then continued for the three-month follow-up period. Most outcomes at baseline, prior to the crossover, during the 'on' and 'off' periods of the crossover and at follow-up were reported separately for the group of 19 participants who preferred the 'on' period and for the group of 5 participants who preferred the 'off' period once the crossover period had ended. For the group of 19 participants, during the one-month period when the stimulator was 'off' the median (range) number of episodes of faecal incontinence per week was 1.7 (0 to 9$)$ compared with 0.7 (0 to 5) during the 'on' period (Analysis 3.2; $\mathrm{P}<0.05$ ), with 0.5 (0 to 11) episodes per week during the three-month follow-up period. 
During the follow-up period 5 (26\%) of the 19 participants were cured (no episodes of faecal incontinence) and 17 (89\%) felt they had improved (Analysis 3.1). The median (range) minutes delay in postponing defaecation was 1.4 (1 to 3 ) during the 'off' period, compared with 1.8 ( 1 to 3 ) during the 'on' period, and 1.9 (1 to 3 ) during the follow-up period (Analysis 3.3). The median (range) episodes of urgency per week were 1.4 ( 0 to 19$)$ during the 'off' period compared with 1 ( 0 to 16$)$ during the 'on' period and $1(0$ to 24) during the follow-up period (Analysis 3.4).

The group of five participants who chose the 'off' period once the crossover period had ended actually experienced an increase in the number of episodes of faecal incontinence when the stimulator was 'on' compared with when it was 'off'. For this group, the median (range) number of episodes of faecal incontinence per week was 1.7 ( 0 to 11$)$ during the one-month 'off' period compared with 3.7 (0 to 11 ) during the one-month 'on' period and 3.5 ( 0 to 10) during the three-month follow-up period (Analysis 3.2). The median (range) minutes delay in postponing defaecation remained relatively unchanged at 1 ( 1 to 3 ) during the 'off' period compared with 1 ( 1 to 2 ) during the 'on' period, and 1.2 (1 to 1.8 ) during the follow-up period (Analysis 3.3). The median (range) episodes of urgency per week were 4.5 (3 to 10) during the 'off' period compared with 8.2 (2 to 19) during the 'on' period and 5.2 ( 0 to 20) during the follow-up period(Analysis 3.4) (Leroi 2005\#).

The Cleveland Clinic Incontinence Score ranges from 0 (normal continence) to 20 (total incontinence). In the trial conducted by Leroi $2005 \#$, for the whole group of participants the median (range) Cleveland Clinic Incontinence Score was 10.5 (4 to 17) during the 'off' period compared with 8.5 (3 to 18) during the 'on' period (Analysis 3.6). For the follow-up period, the Cleveland Clinic Incontinence Score was not reported for the whole group, but separately for the group of 19 who had chosen the 'on' period and for the group of 5 who had chosen the 'off' period following the crossover. For the group of 19 , the median score for the followup period was 10 (3 to 17) while for the group of 5 it was 13 (11 to 18) (Analysis 3.6) (Leroi 2005\#).

In the trial carried out by Kahlke 2015\#, at the end of the crossover while still blinded all patients $(n=14)$ elected to continue with 'on' as their preferred intervention for the final 3 months (final period). FI episodes per week were at a low level (average of 1 $(\mathrm{SD}=1.7)$ ) during the 'on' period, but increased significantly $(\mathrm{P}<$ $0.05)$ on average to $8.4(\mathrm{SD}=8.7)$ during the 'off' period. During the final period FI episodes per week remained low $0.3(\mathrm{SD}=$ $0.5)$ (Analysis 3.2). The CCIS was significantly higher $(\mathrm{P}<0.05)$ during the 'off' period $(14.6(\mathrm{SD}=4.6))$ compared with the 'on' period $(8.7(\mathrm{SD}=3.6))$. During the final period the CCIS was $6.4(\mathrm{SD}=3.3)$ (Analysis 3.6). The overall number of defaecations per week also declined significantly $(\mathrm{P}<0.05)$ in the crossover 'on' period $(10.9(\mathrm{SD}=4.1))$ compared with the 'off' period $(18.2$ $(\mathrm{SD}=8.7))$. Furthermore, during the final period the number of defaecations per week was 9.4 ( $\mathrm{SD}=2.6)$ (Analysis 3.12).

In the trial conducted by Sørensen 2010\# there were no faecal incontinence episodes per week in both the 'on' and 'off' periods (Analysis 3.2). The mean episodes of urgency per week was 4.14 ( -0.16 to 8.44$)$ during the 'off' period and reduced to 2.43 ( -0.23 to 5.1 ) during the 'on' period (Analysis 3.4) (Sørensen 2010\#).

Tjandra 2008 did not report urgency or use of anal plugs. Vaizey 2000\# did not report urgency, the ability to defer defaecation, or incontinence score. Sørensen 2010\# did not report number cured or improved, ability to defer defaecation, and incontinence score. Of the Vaizey 2000\#, Thin 2015, Sørensen 2010\#, and Leroi 2005\# trials, none reported the use of pads, anal plugs or the need for further treatment during follow-up.

\section{Quality of life outcomes}

Tjandra 2008 used the SF-12 and ASCRS FIQL quality of life indexes. SF-12 is developed from the longer SF-36 and generates eight scale scores which can be summarised into a physical and mental summary score. Both of these physical and mental scores have a range from 0 to 100 , higher scores indicating better quality of life. ASCRS FIQL index comprises 29 questions that are grouped into four sections: lifestyle; coping/behaviour; depression/self-perception; and embarrassment. The ASCRS FIQL scores range from one (worst) to five (best). Vaizey 2000\# used the SF-36 tool, while Leroi 2005\# used the French version of the ASCRS FIQL. Thin 2015 used the ASCRS FIQL, SF-36 and EQ5D. EQ-5D, a standardised instrument for use as a measure of health outcome, provides a descriptive profile and a single index value for health status.

\section{SNS versus medical treatment}

In the trial by Tjandra 2008 the SNS group reported better quality of life on FIQL index scores in all four scales compared to the control group in terms of:

1. Lifestyle

- 3 months (MD $-1.22,95 \% \mathrm{CI}-1.52$ to -0.92 )

- 12 months (MD $-1.00,95 \% \mathrm{CI}-1.30$ to -0.70 , Analysis 1.8)

\section{Coping behaviour}

- 3 months (MD, $-1.02,95 \% \mathrm{CI}-1.34$ to -0.70 )

- 12 months (MD, $-0.82,95 \% \mathrm{CI}-1.14$ to -0.50 , Analysis 1.9)

\section{Depression/self-perception}

- 3 months (MD, $-0.63,95 \% \mathrm{CI}-0.89$ to -0.37$)$

- 12 months (MD, $-0.61,95 \% \mathrm{CI}-0.91$ to -0.31 , Analysis 1.10)

\section{Embarrassment}

- 3 months (MD, $-1.19,95 \% \mathrm{CI}-1.47$ to -0.91 )

- 12 months (MD, $-0.98,95 \%$ CI -1.28 to -0.68 , Analysis 1.11) 
However, there were no significant differences between the two groups on the generic quality-of-life scores at 3 or 12 months for either the SF-12 Physical health scale (MD, $-1.68,95 \%$ CI -5.70 to 2.34 at 3 months; $\mathrm{MD},-1.72,95 \% \mathrm{CI}-5.31$ to 1.87 at 12 months, Analysis 1.6); or SF-12 Mental health scale (MD, $-2.34,95 \% \mathrm{CI}-6.23$ to 1.55 at 3 months; MD, $-1.00,95 \%$ CI -4.89 to 2.89 at 12 months, Analysis 1.7).

\section{SNS versus PTNS}

In the trial carried out by Thin 2015 the SNS group reported no statistically significant differences in quality of life FIQL index scores in all four domains compared with the PTNS group in terms of:

1. Lifestyle

- 3 months (MD, $-0.20,95 \% \mathrm{CI}-0.82$ to 0.42 )

- 6 months (MD, $-0.20,95 \% \mathrm{CI}-0.82$ to 0.42 , Analysis

2.3)

2. Coping

- 3 months (MD, $-0.20,95 \% \mathrm{CI}-0.72$ to 0.32 )

- 6 months (MD, $-0.50,95 \% \mathrm{CI}-1.09$ to 0.09 , Analysis

2.4)

$$
\begin{aligned}
& \text { 3. Depression } \\
& \text { - } 3 \text { months (MD, } 0.10,95 \% \mathrm{CI}-0.46 \text { to } 0.66) \\
& \text { - } 6 \text { months (MD, }-0.10,95 \% \mathrm{CI}-0.66 \text { to } 0.46 \text {, Analysis } \\
& \text { 2.5) } \\
& \text { 4. Embarrassment } \\
& \text { - } 3 \text { months (MD, }-0.30,95 \% \mathrm{CI}-0.82 \text { to } 0.22) \\
& \text { - } 6 \text { months (MD, }-0.60,95 \% \mathrm{CI}-1.16 \text { to }-0.04 \text {, Analysis } \\
& \text { 2.6) }
\end{aligned}
$$

However, EQ-5D scores were not significantly different between the two groups (at three months $\mathrm{MD}, 0.06,95 \% \mathrm{CI}-0.17$ to 0.29 ; at six months $\mathrm{MD}, 0.13,95 \% \mathrm{CI}-0.08$ to 0.34 , Analysis 2.7).

\section{Faecal incontinence: crossover trials}

Raw data for the SF-36 was unavailable, but was reported as within patient changes (from baseline to three months and six months respectively). Increases in physical role was seen for SNS (at six months: 25.0 versus 0.0, SNS and PTNS respectively, Analysis 3.7 ), while modest increases were observed for emotional role (at six months: 17.8 versus 16.7, SNS and PTNS respectively, Analysis 3.7 ) and social functioning (at six months: 17.5 versus 10.9, SNS and PTNS respectively, Analysis 3.7) for both interventions.

Vaizey 2000\# reported quality of life before implantation of the stimulator and nine months after implantation, prior to the crossover period. There was an overall improvement in both participants but especially so in one participant in terms of the domains of bodily pain (30 versus 100); role-physical (0 versus 100); social function (12 versus 100); and vitality (10 versus 80 ) Analysis 3.7. Leroi 2005\# recorded quality of life using the French version of the FIQL instrument at baseline and again during the final three-month follow-up period, noting a statistically significant ( $\mathrm{P}$ $<0.05)$ improvement in the median scores for all domains: lifestyle (1.7 versus 3.2); coping/behaviour (1.5 versus 2.7); depression/ self-perception (2.2 versus 3.6); and embarrassment (1.3 versus 2.3) Analysis 3.9.

Sørensen 2010\# and Kahlke 2015\# did not report quality of life of participants.

\section{Surrogate measures (anorectal manometry)}

Tjandra 2008 reported anal manometry for both groups at base line and only the SNS group during the follow-up period. There was a non-significant $(\mathrm{P}>0.05)$ change in the two parameters

reported. In the SNS group the mean resting pressure $\left(\mathrm{cm} \mathrm{H}^{2} \mathrm{O}\right)$ was $40.4(\mathrm{SD}=15.9)$ at baseline and $40.9(\mathrm{SD}=21.9)$ at 12 months, Analysis 3.11. Similarly, in the SNS group the mean squeeze pressure ( $\left.\mathrm{cm} \mathrm{H}_{2} \mathrm{O}\right)$ was $83.2(\mathrm{SD}=39.6)$ at baseline and 90.2 (SD = 54.9) at 12 months (Tjandra 2008), Analysis 3.11 . Moreover, in the trial conducted by Sørensen 2010\#, the mean

(95\% CI for mean) resting anal pressure ( $\left.\mathrm{cm} \mathrm{H}_{2} \mathrm{O}\right)$ decreased from 84.2 (70.4 to 98.3) when the stimulator was 'on' to 106.2 (71.1 to 141.4 ) when the stimulator was 'off', Analysis 3.11. However, the mean values for squeeze pressure remained the same during the 'on' and 'off' periods: 223.0 (159.1 to 287.0) and 223.0 (153.7 to 292.4) respectively, Analysis 3.11. With regards to rectal sensory threshold (ml), the mean (95\% CI for mean) threshold sensation was 50.0 (34.6 to 65.4) during the 'off' period which decreased to 27.1 (17.8 to 36.4) when 'on'; with corresponding values for urge of 82.9 (64.8 to 101) and 60 (48.7 to 71.3), Analysis 3.11 . Contrastingly, mean maximum-tolerated volume $(\mathrm{ml})$ remained the same during the 'off' and 'on' periods: 124 (106 to 142) and 124 (82.4 to 165.6) respectively (Sørensen 2010\#), Analysis 3.11. In the trial conducted by Vaizey 2000\# the mean (range) resting

anal pressure ( $\mathrm{cm} \mathrm{H}_{2} \mathrm{O}$ ) improved from 43 (35 to 50) when the stimulator was 'off' to 58 (45 to 70) when it was 'on'; with the corresponding values for squeeze pressure also improving from 65 (60 to 70 ) to 95 (90 to 100), Analysis 3.11. In terms of rectal sensation to distention $(\mathrm{ml})$, the mean (range) threshold sensation was 38 (25 to 50) during the 'off' period compared with 68 (45 to 90) during the 'on' period, with corresponding values for urge of 85 (70 to 100 ) and 103 ( 85 to 120 ); and, for maximum-tolerated volume, 135 (120 to 150) during the 'off' period compared with 140 (130 to 150) during the 'on' period, Analysis 3.11.

Leroi 2005\# reported anorectal manometry measures separately for the group of 19 participants who preferred the 'on' period and for the group of five participants who preferred the 'off' period following the crossover. For the group of 19, the median (range) 
maximum resting pressure ( $\mathrm{cm} \mathrm{H}_{2} \mathrm{O}$ ) improved from 37 (26 to 100) during the one-month period when the stimulator was 'off' to 50 (27 to 155 ) when it was 'on,' Analysis 3.11. The median (range) maximum squeeze pressures improved from 49 (10 to 98) during the 'off' period to 53 (6 to 326) during the 'on' period, Analysis 3.11. The median (range) threshold, constant sensation volume and maximum tolerated volume (all $\mathrm{ml}$ ) were reported only for baseline and the final three-month follow-up period following crossover. Threshold values were 25 (10 to 120 ) at baseline compared with 30 (10 to 120) during the follow-up period, with the corresponding values for constant sensation volume of 100 (40 to 230 ) and 85 (30 to 300 ), while maximum tolerated volume was 185 (80 to 350 ) at baseline compared with 170 (40 to 275) at follow-up, Analysis 3.11.

For the group of five participants who preferred the 'off' period following the crossover period, the median (range) maximum rest-

ing pressure ( $\mathrm{cm} \mathrm{H}_{2}$ 0) improved from 50 (39 to 98) during the 'off' period to 64 (37 to 98) during the 'on' period (Leroi 2005\#), Analysis 3.11. However, the median (range) maximum squeeze

pressures ( $\mathrm{cm} \mathrm{H}_{2}$ 0) decreased from 54 (37 to 110) during the 'off' period to 30 (21 to 90) during the 'on' period, Analysis 3.11. The median (range) rectal volume sensation values $(\mathrm{ml})$ remained relatively unchanged between baseline and follow-up, with threshold values 10 (10 to 40) at baseline and 10 (10 to 50) during follow-up; constant sensation volume 50 (20 to 90) at baseline and 50 (20 to 95) at follow-up; and maximum tolerated volume 200 (80 to 300) at baseline compared with 195 (100 to 300) at followup (Leroi 2005\#), Analysis 3.11.

Thin 2015 and Kahlke 2015\# did not report anorectal manometry outcomes.

\section{Adverse effects}

\section{Faecal incontinence: SNS versus medical treatment}

In the trial conducted by Tjandra 2008, adverse events reported for the SNS group consisted of implantation site pain (6\%), particularly in slimmer participants; seroma (2\%), which required percutaneous aspiration; and excessive tingling in the vaginal region $(9 \%)$.

\section{Faecal incontinence: SNS versus PTNS}

In the trial carried out by Thin 2015, adverse events reported for the SNS group include mild ipsilateral leg pain during temporary testing $(\mathrm{n}=1)$ and stimulator-site pain following insertion of neurostimulator $(\mathrm{n}=2)$.

\section{Faecal incontinence: crossover trials}

Leroi $2005 \#$ reported that, of 27 participants receiving a permanent implant, 4 (15\%) experienced adverse events prior to the commencement of the crossover period, resulting in explantation of the stimulator. Three of the explantations were due to unresolved pain and one was for recurrent infection. Another participant suffered an adverse event (stroke), not related to SNS, prior to the crossover period. Leroi 2005\# did not report whether there had been any adverse events during the crossover period or threemonth follow-up period. Vaizey 2000\# and Sørensen 2010\# did not report whether any adverse events had occurred during the course of the trial.

In the trial carried out by Kahlke 2015\#, adverse events reported for the enrolled participants after implantations included: haematoma formation $(n=3)$, misplacement of tined lead (1), and pain at stimulator site $(\mathrm{n}=1)$.

\section{Health economics}

None of the trials (Kahlke 2015\#; Kenefick 2002\#; Leroi 2005\#; Sørensen 2010\#; Thin 2015; Tjandra 2008; Vaizey 2000\#) provided any information on costs within the trials.

\section{Other outcomes quoted by trial authors and judged to be important}

Leroi 2005\# reported bowel movements per week; and regarding anorectal manometry, reported squeeze pressure duration (seconds) and constant sensation volume (ml). For the 19 participants who preferred the 'on' period once the crossover period had ended, during the one-month period when the stimulator was 'off' the number of bowel movements per week was 10.6 (6 to 33) compared with 10.2 (5 to 26) during the 'on' period, and 10.6 (7 to 37) during the follow-up period, Analysis 3.12. For the group of five participants who preferred the 'off' period once the crossover period had ended, the number of bowel movements per week during the 'off' period was 12.7 (8 to 19) compared with 11.2 (7 to 32) during the 'on' period, and 11.7 (7 to 32) during the followup period, Analysis 3.12. For the group of 19 participants, squeeze pressure duration was 21 (4 to 32 ) seconds during the 'off' period compared with 18 (6 to 92) during the 'on' period; the corresponding values for the group of five participants were 40 ( 5 to 40) during the 'off' period compared with 32 (23 to 38) during the 'on' period, Analysis 3.11. For the group of 19 participants, the median (range) constant sensation volume values for baseline were 100 (40 to 230) compared with 85 (30 to 300 ) during the follow-up period; the corresponding values for the group of five participants remained relatively unchanged at 50 (20 to 90) at baseline and 50 (20 to 95) at follow-up, Analysis 3.11.

Sørensen 2010\# reported mean (95\% CI for mean) soiling per week for the participants which decreased from 1.86 (0.29 to 3.43 ) during the 'off' period to 0.71 ( -0.69 to 2.11 ) during the 'on' 
period, Analysis 3.13. Sørensen 2010\# also reported mean (95\% CI for mean) bowel movements per week which reduced from 12.1 (6.32 to 17.9) during the 'off' period to 8.86 (6.21 to 11.5 ) during the 'on' period, Analysis 3.12. Similarly, the mean (95\% CI for mean) passive leakage per week reduced from $0.43(-0.41$ to 1.27) during the 'off' period to 0 during the 'on' period, Analysis 3.16

Moreover, Tjandra 2008 reported days with incontinence and days with staining per week. SNS was better than control in terms of:

- Number of days with faecal incontinence per week (MD

$-1.90,95 \% \mathrm{CI}-2.66$ to -1.14 at 3 months; and MD -2.10 , $95 \% \mathrm{CI}-3.01$ to -1.19 at 12 months, Analysis 1.3 );

- Number of days with faecal staining per week (MD -3.20, $95 \% \mathrm{CI}-3.90$ to -2.50 at 3 months; and MD $-3.10,95 \% \mathrm{CI}$ -3.89 to -2.31 at 12 months, Analysis 1.4 );

\section{Constipation}

Two crossover trials investigated the effects of SNS for constipation (Dinning 2015\#; Kenefick 2002\#).

\section{Number improved, bowel movements, percentage time with abdominal pain and bloating, constipation score}

In the trial conducted by Dinning 2015\#, during the period when the stimulator was turned off (sham) the participants on average had stool frequency of 6.4 compared with an average of 6.6 when the stimulator was turned on (Analysis 4.6). With regards to bowel movements per week, this was on average 4.0 during the off period compared with 4.3 during the on period, Analysis 4.1. Furthermore, on average the pain score per week was 1.0 during the on period compared with 0.9 during the off period, Analysis 4.7. Bloating score on average per week was 1.2 in both the 'off' and 'on' periods, Analysis 4.8.

In the trial conducted by Kenefick 2002\#, both participants experienced an improvement, both in terms of bowel movements per week and the percentage of time with abdominal pain and bloating, Analysis 4.1, Analysis 4.2. During the period when the stimulator was 'off' the participants experienced an average of two bowel movements (episodes of defaecation) per week, compared with five when the stimulator was 'on', an increase of $150 \%$ (Kenefick 2002\#), Analysis 4.1. The average percentage of time with abdominal pain and bloating was $79 \%$ during the 'off' period compared with 33\% during the 'on' period, Analysis 4.2.

The Wexner constipation score ranges from 0 (normal) to 30 (severe constipation). The mean (range) scores for the participants improved from 14 (13 to 15 ) during the 'off' period to 9 (5 to 13 ) during the 'on' period, Analysis 4.3. Kenefick 2002\# also noted an improvement in symptoms with the Symptom Analogue Score, with mean (range) scores during the 'off' period of 32 (30 to 33), compared with scores of 74 (60 to 88 ) during the 'on' period, Analysis 4.4. Dinning 2015\# did not report constipation scores.

\section{Quality of life}

Kenefick 2002\#, using the SF-36 tool, reported a marked improvement in both participants after a year of chronic stimulation compared with baseline, although no data were provided. Dinning 2015\# utilised the SF-36 tool; however no significant changes in the quality-of-life scores were reported, Analysis 4.9.

\section{Surrogate measures (anorectal manometry)}

In the trial conducted by Kenefick 2002\#, the mean (range) maximal resting pressures ( $\mathrm{cm} \mathrm{H}_{2}$ 0) improved from 51 (39 to 63) when the stimulator was 'off' to 76 (68 to 84) when it was 'on', with the corresponding values for maximal squeeze pressures also improving from 54 ( 51 to 57 ) during the 'off' period to 93 (41 to 145 ) during the 'on' period, Analysis 4.5. In terms of threshold sensation ( $\mathrm{ml}$ air), the mean (range) values were 35 (30 to 40) during the 'off' period compared with 18 (15 to 20 ) during the 'on' period; while the corresponding figures for urgency were $70(60$ to 80 ) compared with 34 (33 to 35 ); and for maximum-tolerated volumes, 103 ( 85 to 120 ) during the 'off' period compared with 68 (65 to 70) during the 'on' period, Analysis 4.5. Dinning 2015\# did not report anal manometry.

\section{Adverse effects}

Kenefick 2002\# reported that there were no adverse events during the course of the trial. Dinning 2015\# reported 73 adverse events, which includes pain at site of the implanted pulse generator (32), wound infection (12) and urological symptoms (17), Analysis 4.10 .

\section{Health economics}

Kenefick 2002\# and Dinning 2015\# provided no information on costs.

\section{DISCUSSION}

\section{Summary of main results}

The finding of this review is that SNS for faecal incontinence can significantly improve faecal continence in some selected people, bearing in mind the limited evidence from randomised controlled trials.

On the other hand, we found that SNS did not seem to improve symptoms in people with constipation, but there were only two randomised trials providing evidence, of which one trial had only two participants. 
Only eight trials, comprising two parallel group trials (Thin 2015; Tjandra 2008), and six small crossover trials were identified that met our inclusion criteria (Dinning 2015\#; Kahlke 2015\#; Kenefick 2002\#; Leroi 2005\#; Sørensen 2010\#; Vaizey 2000\#). Six of these trials focused on SNS for faecal incontinence (FI) (Kahlke 2015\#; Leroi 2005\#; Sørensen 2010\#; Thin 2015; Tjandra 2008; Vaizey 2000\#), while two assessed the effects of SNS for constipation (Dinning 2015\#; Kenefick 2002\#). Two of the trials each contained only two participants (Kenefick 2002\#; Vaizey 2000\#); while the trial by Sørensen 2010 \# enrolled seven participants, and Kahlke 2015\# enrolled 16 participants. Although still relatively small, the trial by Leroi 2005\# enrolled 34 participants; and Thin 2015 enrolled 40 participants. For constipation, Dinning 2015\# enrolled 59 participants; whilst for FI, Tjandra 2008 enrolled 120 participants, making them the largest of the trials that were included.

\section{Faecal incontinence}

The trials conducted by Vaizey 2000\# and Leroi 2005\# suggest that for some selected participants, SNS can reduce episodes of faecal incontinence and urgency and improve the ability to defer defaecation, leading to a better quality of life. However, a minority may get worse despite apparently successful testing before permanent implantation. Sørensen 2010\# found that SNS can reduce number of defaecations, urgency episodes, soiling and passive leakage, while increasing first sensation of content in the rectum. Similarly, Kahlke 2015\# found that SNS significantly reduces faecal incontinence episodes and bowel movements and improves CCIS scores. Furthermore, the trial by Tjandra 2008 suggests that sacral nerve stimulation in selected participants with severe faecal incontinence can significantly reduce episodes of faecal incontinence as well as improving the ability to defer defaecation but this did not quite result in measurable improvement in quality of life. Additionally, the trial by Thin 2015 found that in the short term SNS provides some clinical benefit to patients with FI.

In the trial by Leroi 2005\#, at the end of the crossover period and while still blinded, the participants chose the period of stimulation ('on' or 'off') they had preferred and the mode of stimulation corresponding to the selected period ('on' or 'off') was then continued for the 3-month follow-up. Rather than reporting outcomes for the trial group as a whole, Leroi 2005\# reported most outcomes (at baseline; prior to the crossover period; during the 'on' and 'off' crossover periods; and at follow-up) separately for the group of 19 participants who preferred the 'on' period and the group of 5 who preferred the 'off' period. The characteristics of the two groups differed somewhat in terms of type and duration of faecal incontinence. The two groups responded differently to SNS, with the group of 19 reporting a $59 \%$ reduction in episodes of faecal incontinence per week, from a median of 1.7 during the 'off' period to 0.7 during the 'on' period. In contrast, the group of five experienced a $118 \%$ increase in episodes of faecal inconti- nence per week: from a median of 1.7 during the 'off' period to 3.7 during the 'on' period.

If results for the 'on' and 'off' periods of the crossover had been reported for the trial group as a whole then in terms of episodes of faecal incontinence per week, ability to defer defaecation, and episodes of urgency, SNS would have been shown to be less effective compared with the results for the group of 19 participants who preferred the 'on' period. The fact that five participants chose the mode of stimulation corresponding to the 'off' period at the end of the crossover emphasises the fact that SNS for faecal incontinence is not an effective treatment for all patients eligible for the procedure, even taking into account that temporary percutaneous stimulation for a two- to three-week period prior to permanent implantation allows selection of those for whom permanent SNS is likely to be effective. Despite having met the criteria to progress from temporary to permanent stimulation (at least a $50 \%$ reduction in the number of episodes of faecal incontinence per week or a $50 \%$ reduction in the number of episodes of faecal urgency per week, or both) these five participants actually experienced an increase rather than a reduction in episodes of faecal incontinence during the 'on' period compared with the 'off' period.

\section{Adverse effects}

Vaizey 2000\# and Sørensen 2010\# did not report adverse effects. However, the other four trials did (Kahlke 2015\#; Leroi 2005\#; Thin 2015; Tjandra 2008). Leroi 2005\# reported a relatively high adverse event rate, with $4(15 \%)$ of the 27 participants who received a permanent implant experiencing an adverse event requiring removal (explantation) of the stimulator, all prior to the crossover period. Three of the explantations were because of unresolved pain, while the fourth was because of recurrent infection. These adverse events were resolvable through removal of the device, and no adverse events appeared to have occurred during the second crossover period or follow-up period. In the trial conducted by Tjandra 2008, adverse events included pain at the site of implantation, seroma which required percutaneous aspiration, and excessive tingling in the vaginal region. However, no septic complication requiring explantation or urinary/sexual function-related adverse events were reported (Tjandra 2008). Also, in the trial carried out by Thin 2015, adverse effects included mild ipsilateral leg pain during temporary testing which resolved after removal of the temporary lead and insertion of the permanent implant. Other adverse events experienced include stimulator-site pain following insertion of the neurostimulator, which resolved with adjustment of stimulator settings (Thin 2015). Finally, in the trial conducted by Kahlke 2015\#, adverse events reported for the enrolled participants after implantations included: haematoma formation ( $\mathrm{n}=$ $3)$, misplacement of tined lead $(\mathrm{n}=1)$ and pain at stimulator site $(\mathrm{n}=1)$. 


\section{Constipation}

In the trial of only two participants conducted by Kenefick 2002\# assessing the effects of SNS for constipation, bowel movements per week were increased by $150 \%$, while the time with abdominal pain and bloating decreased from $79 \%$ during the 'off' period to $33 \%$ during the 'on' period; the Wexner constipation score showed an improvement of 36\%. The much larger RCT of 59 participants carried out by Dinning 2015\# found that in patients with refractory slow transit constipation, SNS did not improve the frequency of complete bowel movements per week.

\section{Adverse effects}

Dinning 2015\# reported 73 adverse events which included pain at the site of the implanted pulse generator (32), wound infection (12), and urological symptoms (17). Kenefick 2002\# reported that no adverse effects had occurred.

\section{Overall completeness and applicability of evidence}

This systematic review includes eight trials, all of which are RCTs. Six assessed SNS for faecal incontinence (219 participants enrolled overall) while two trials assessed SNS for constipation (61 participants enrolled). In the interval since the first Cochrane review on this subject (Mowatt 2007), SNS has become well established as first-line minimally-invasive treatment for patients with FI failing conservative measures, with recognition of this fact by regulatory agencies (FDA 1998; NICE 2007). Such widespread acceptance has been based almost exclusively on post-registration data published in the form of numerous case series, including some large well-designed prospective non-randomised studies (Wexner 2010).

The availability of data from randomised trials has progressed slightly with five new trials being added to this update (Dinning 2015\#; Kahlke 2015\#; Sørensen 2010\#; Thin 2015; Tjandra 2008). Within the included trials, potentially relevant primary outcome measures (such as the proportion of participants either cured or improved, having urgency, and using pads/plugs) were not reported consistently. Other primary outcome measures such as incontinence scores and quality-of-life scores were also not consistently reported. This variation has made comparison between the trials problematic. The addition of these trials does not change the conclusions reached in the previous review and provides further evidence for a reduction in episodes of faecal incontinence and urgency, and improvement in the ability to defer defaecation.

\section{Surrogate outcome measures}

Anorectal manometry measurements, although commonly reported in trials, does not appear to provide information that can be used to determine which patients will benefit from SNS, and so does not appear to provide clinically useful information.

\section{Quality of the evidence}

In terms of methodological quality, the main uncertainty in judging trial bias stemmed from lack of clarity around randomisation techniques and allocation concealment. Additionally, participant blinding in the trials is complicated by the widely-acknowledged preference of the majority of participants for suprasensory stimulation (meaning that the current needs to be so high to be effective that the patient is aware of it) which makes allocation concealment and use of valid sham therapy problematic. Hence the observed effect may have been overestimated due to a placebo effect.

Moreover, some trials had little or no wash-out period between the two crossover periods with short treatment duration, thus carryover effects when the device was used first in the 'on' position may exist.

Another methodological limitation is the heterogeneity in the collection of data and method of analysis: some trials reported outcomes at specific time points whereas others reported average outcome for the whole cohort with an average follow-up period. Hence formal statistical synthesis was generally not possible due to the heterogeneity in reported outcomes and styles of reporting, as well as differences in the populations, interventions and trial designs.

Some of the trials included in this review had a small sample of participants which would affect estimates of treatment differences. Furthermore, follow-up period was generally inadequate and needs to be longer to further evaluate long-term effects of SNS.

\section{Agreements and disagreements with other studies or reviews}

\section{Faecal incontinence}

Our findings that SNS for faecal incontinence can significantly improve faecal continence in some selected patients is in agreement with an earlier systematic review conducted in the UK of the efficacy and safety of SNS for faecal incontinence by Fraser 2004. This was submitted to the National Institute for Health and Clinical Excellence (NICE) Interventional Procedures Programme in 2004 as part of NICE's consideration of this topic (Fraser 2004). The systematic review conducted by Fraser 2004 included one trial that is also included in this review (the crossover trial conducted by Vaizey 2000\#), a non-randomised multicentre trial involving 37 participants, and six case series enrolling 266 participants, of whom 149 received permanent implants. The review reported that $41 \%$ to $75 \%$ of participants achieved complete faecal continence and $75 \%$ to $100 \%$ experienced an improvement of $50 \%$ or more 
in the number of faecal incontinence episodes. In the multicentre trial and all six case series, SNS resulted in a decrease in the number of episodes of faecal incontinence per week (see Table 1) (Fraser 2004). The review also noted a relatively high adverse event rate: amongst 149 participants receiving permanent implants in the case series, 19 (13\%) adverse events were reported, although these resulted in the explantation of only four devices. Amongst 34 participants receiving permanent implants in the multicentre trial, 15 (44\%) adverse events were reported, resulting in the removal of two devices.

Our findings that SNS for faecal incontinence can significantly improve faecal continence in some selected patients is also in agreement with a systematic review conducted in the UK of clinical effectiveness of neuromodulation in the treatment of faecal incontinence by Thin 2013. This systematic review for SNS included 61 eligible studies of which the majority were prospective case series $(n=50)$ and only two were randomised clinical trials. The two randomised trials were the parallel-group study by Tjandra 2008 and the crossover study by Leroi 2005\#, both included in our current systematic review. The review reported the success rates for SNS (based on at least $50 \%$ improvement in FI episodes per week) were $63 \%$ (range $33 \%$ to $36 \%$ ), $58 \%$ (range $52 \%$ to $81 \%$ ) and $54 \%$ (range $50 \%$ to $58 \%$ ) in the short, medium and long term respectively. Furthermore, 36\% (range $8 \%$ to $68 \%$ ), 32\% (range $4 \%$ to $74 \%$ ) and $20 \%$ (range $2 \%$ to $48 \%$ ) of participants achieved complete faecal continence.

Similarly, a meta-analysis conducted by Tan 2011 was in agreement with our findings. In their review 34 studies were included of which the majority $(n=28)$ were prospective non-randomised trials (Tan 2011). The remaining studies included three randomised control trials. Two of the RCTs were crossover trials (Leroi 2005\#; Vaizey 2000\#), while the third was a parallel-group trial (Tjandra 2008): all are included in the current review. Tan and colleagues found SNS significantly improved the faecal incontinence episodes per week (weighted mean difference -6.83 ; $95 \%$ confidence interval -8.05 to -5.60 ; $\mathrm{P}<0.001)$ compared with maximal conservative therapy (Tan 2011). Additionally, the adverse events rate reported was $15 \%$ for permanent SNS, 3\% resulting in permanent explantation.

\section{Constipation}

The systematic review by Jarrett 2004 included two case series involving 20 participants and concluded that SNS improved evacuation difficulty, increased the frequency of defaecation, and decreased the time with abdominal pain and bloating. Furthermore, a systematic review by Sharma 2013 of SNS for constipation included 10 studies of which one was a double-blind, placebo-controlled crossover study (Kenefick 2002\#). This study found that SNS can improve bowel frequency and reduce constipation symptoms (Sharma 2013). However, our current review which included two randomised controlled trials involving 61 participants does not concur with the review by Jarrett 2004 and Sharma 2013. We found that SNS does not improve symptoms in patients with constipation but the number of participants was too small to be conclusive.

\section{A U THORS' CONCLUSIONS}

\section{Implications for practice}

It remains true that SNS is not effective for all patients with severe faecal incontinence and even some of those who meet the criteria to progress from temporary to permanent stimulation may then go on to experience an increase rather than a reduction in episodes of faecal incontinence. The practice of employing temporary, percutaneous stimulation for a two- to three-week period may identify those most likely to respond positively to a permanent implant but does not identify all those for whom a permanent implant will be beneficial. Further, it must be noted that the failure to implant patients who have not benefited from a testing phase means that the true utility of this extra procedure (based on standard statistical measures of diagnostic accuracy) has not been studied. The adverse event rate leading to removal of the permanent stimulator was high at $15 \%$ in the Leroi 2005 \# trial but less $(6 \%)$ in the larger trial of Tjandra 2008, and less also in the trials by Thin 2015 and Dinning 2015\#.

In summary, this review supports the view that SNS has an important role for selected patients with FI failing conservative therapies thus reserving direct surgery to the anal sphincter for particular highly-selected patients or perhaps those failing SNS: such surgery carries a high risk of serious morbidity and is not always successful (Baeten 1995; Lehur 1998; Malouf 2000). This position may change with further potentially-disruptive technologies at various stages of trial evaluation (Hotouras 2014; Lehur 2010; Ratto 2011).

Although there have been considerably fewer published case series for patients with chronic constipation, available prospective case series data support a beneficial effect in most, including in the relatively large European study (Kamm 2010). Despite this the current clinical view is that the overall results are less good than for FI (Knowles 2009; Maeda 2010); and that adverse events are more common (Maeda 2010). The data in the current review involving two crossover trials of 61 participants do not show any beneficial effect for SNS when treating patients with constipation but the information is limited by the small number of participants.

\section{Implications for research}

The current literature base in respect of controlled trials must surely be considered inadequate for an invasive and expensive therapy which, for urinary and faecal incontinence, has now been implanted in 145,000 patients worldwide. The proof of effectiveness, 
and indeed efficacy, of SNS is currently based almost entirely on post-registration (phase IV) data presented by enthusiastic individuals in ad hoc case series. To date, there has been no definitive phase III study of effectiveness of SNS versus sham stimulation nor, importantly, any phase II study designed to combine efficacy with proof of mechanism. This latter point is important for the reasons outlined above, i.e. that a proportion of seemingly wellselected patients fail therapy over time. In the absence of knowledge of mechanism, valid biomarkers for patient selection will be difficult to determine. Further trials will also need to compare SNS with other therapies which fall into the minimally-invasive therapy cluster, i.e. between conservative approaches and drugs versus major reconstructive surgery.

The design of all future trials will need to address the deficiencies of current trials but this will not be easy. Design points that should be considered are:

(1) the inadequacy of current outcome measures, especially the dependency on bowel diaries (Vaizey 2014);

(2) the need for meaningful follow-up (at least one year and ideally two years or more);

(3) the avoidance of crossover designs with short treatment durations and lack of wash-out periods. (It is accepted that parallel arm trials require greater recruitment numbers to mitigate against baseline variances. However, it will be important to assess primary efficacy in treatment of naïve patients rather than switching the device on or off in patients who have already been selected on the basis of successful therapy progression);

(4) attention to participant blinding as well as observer blinding. (This is complicated by the widespread acknowledgement that some patients require suprasensory stimulation thus making allocation concealment and selection of a valid sham therapy difficult);

(5) interpretation of the temporary testing phase as a diagnostic test or rather as part of the therapy itself (this has implications for presenting data as intent-to-treat). As noted above, the validity of this testing phase has in any case been questioned for discriminantvalue and health-economic reasons.

\section{ACKNOW LEDGEMENTS}

We thank Sheila Wallace for searching the Cochrane Incontinence Group Specialised Trials Register.

We also acknowledge the authors (G Mowatt, C Glazener, and M Jarrett) of the original review (Mowatt 2007) for their contribution.

\section{R E F E R E N C E S}

\section{References to studies included in this review}

\section{Dinning 2015\# \{unpublished data only\}}

Dinning PG, Hunt L, Patton V, Tzang T, Szczesniak $\mathrm{M}$, Gebski $\mathrm{V}$, et al. Treatment efficacy of sacral nerve stimulation in slow transit constipation: A two phase, double blind randomized controlled crossover study. American Journal of Gastroenterology 2015;110(5):733-40. [: sr-incont67952]

Kahlke 2015\# \{published data only\} Kahlke V, Topic H, Peleikis HG, Jongen J. Sacral nerve modulation for fecal incontinence: results of a prospective single-center randomized crossover study. Diseases of the Colon \& Rectum 2015;58:235-40. [: sr-incont66462]

Kenefick 2002\# \{published data only\}

Kenefick NJ. Sacral nerve neuromodulation for the treatment of lower bowel motility disorders. Annals of The Royal College of Surgeons of England 2006;88(7):617-23. [: 22235]

* Kenefick NJ, Vaizey CJ, Cohen CR, Nicholls RJ, Kamm MA. Double-blind placebo-controlled crossover study of sacral nerve stimulation for idiopathic constipation. British Journal of Surgery 2002;89(12):1570-1. [: sr-incont16145]
Leroi 2005\# \{published data only\} Leroi AM, Parc Y, Lehur PA, Mion F, Barth X, Rullier E, et al. Efficacy of sacral nerve stimulation for fecal incontinence: results of a multicenter double-blind crossover study. Annals of Surgery 2005;242(5):662-9. [: sr-incont21269]

Sørensen 2010\# \{published data only\}

Sørensen M, Thomsen F. Sacral nerve stimulation increases rectal sensitivity in patients with faecal incontinence: results of a randomised double-blinded crossover study (Abstract number 437). Proceedings of the Joint Meeting of the International Continence Society (ICS) and the International Urogynecological Association, 2010 Aug 2327, Toronto, Canada. 2010. [: sr-incont40174]

Thin 2015 \{published data only\}

Thin NN, Taylor SJC, Bremner SA, Emmanuel AV, Hounsome N, Williams NS, et al. Randomized clinical trial of sacral versus percutaneous tibial nerve stimulation in patients with faecal incontinence. British Journal of Surgery 2015;102(4):349-58. [: sr-incont66403]

Tjandra 2008 \{published data only\} Tjandra J, Lim J, Green C, Carey M. Sacral neuromodulation in patients with faecal incontinence: a randomized controlled study on efficacy and quality of life (Abstract 
number 090). Colorectal Disease 2005;7(Suppl 1):31. [: sr-incont24001]

Tjandra JJ, Chan MKY, Yeh CH, Murray-Green C. Sacral nerve stimulation is more effective than optimal medical therapy for severe fecal incontinence: A randomized, controlled study. Diseases of the Colon and Rectum 2008;51 (5):494-502. [: sr-incont27640]

Vaizey 2000\# \{published data only\}

Vaizey CJ, Kamm MA, Roy AJ, Nicholls RJ. Doubleblind crossover study of sacral nerve stimulation for fecal incontinence. Diseases of the Colon \& Rectum 2000;43(3): 298-302. [: sr-incont11184]

\section{References to studies excluded from this review}

Dinning 2007 \{published data only\}

Dinning PG, Fuentealba SE, Kennedy ML, Lubowski DZ, Cook IJ. Sacral nerve stimulation induces pancolonic propagating pressure waves and increases defecation frequency in patients with slow-transit constipation. Colorectal Disease 2007;9(2):123-32. [: sr-incont22557]

Dinning 2013 \{published data only\}

Dinning P, Patton V, Hunt L, Gebski V, Jones M, Stewart P, Lubowski D, Cook I. Efficacy of sacral nerve stimulation for severe slow transit constipation: A randomised, doubleblind, placebo-controlled, crossover study. Diseases of the Colon and Rectum 2013;56(4):e116. [: sr-incont49771]

Knowles 2012 \{published data only\}

Knowles CH, Thin N, Gill K, Bhan C, Grimmer K, Lunniss $\mathrm{PJ}$, et al. Prospective randomized double-blind study of temporary sacral nerve stimulation in patients with rectal evacuatory dysfunction and rectal hyposensitivity. Annals of Surgery 2012;255(4):643-9. [: sr-incont45223]

\section{References to ongoing studies}

\section{Borjesson 2013 \{published data only\}}

Borjesson L. Sacral nerve stimulation vs anal bulking for faecal incontinence - a randomised controlled trial. http:// isrctn.org/ISRCTN00247992 2013. [: sr-incont64540]

Jayne 2014 \{published data only\}

Jayne D. Safari: Sacral nerve stimulation versus the FENIX TM magnetic sphincter augmentation for adult faecal incontinence: a prospective, UK multi-site, parallelgroup, randomised clinical study investigating the safety and efficacy of the FENIX TM magnetic sphincter augmentation (MSA) compared to sacral nerve stimulation (SNS) for adult FI. http://isrctn.org/ISRCTN16077538 2014. [: sr-incont64510]

Vallance 2014 \{published data only\}

Vallance A, Brown S, Nugent K, Lodge J, Protheroe D, Neville K, et al. Study design: Sacral nerve stimulation versus the FENIXTM magnetic anal sphincter for adult faecal incontinence: A randomised investigation (SaFaRI) (Abstract number W191). Colorectal Disease 2014;16(Suppl s2):197. [: sr-incont66262]

\section{Additional references}

\section{Altomare 2004}

Altomare DF, Binda GA, Dodi G, La Torre F, Romano G, Rinaldi M, et al. Disappointing long-term results of the artificial anal sphincter for faecal incontinence. The British Journal of Surgery 2004;91(10):1352-3.

Baeten 1991

Baeten CG, Konsten J, Soeters PB, Spaans F, Visser R, Habets AM, et al. Dynamic graciloplasty for treatment of faecal incontinence. Lancet 1991;338(8776):1163-5.

Baeten 1995

Baeten CG, Geerdes BP, Adang EM, Heineman E, Konsten J, Engel GL, et al. Anal dynamic graciloplasty in the treatment of intractable fecal incontinence. The New England Journal of Medicine 1995;332(24):1600-5.

Brindley 1974

Brindley GS. Emptying the bladder by stimulating sacral ventral roots. The Journal of Physiology 1974;237(2):15-6.

Brown 2010

Brown SR, Wadhawan H, Nelson RL. Surgery for faecal incontinence in adults. Cochrane Database of Systematic Reviews 2010, Issue 9. [DOI: 10.1002/ 14651858.CD001757.pub4]

\section{Burgell 2012}

Burgell RE, Bhan C, Lunniss PJ, Scott SM. Fecal incontinence in men: coexistent constipation and impact of rectal hyposensitivity. Diseases of the Colon \& Rectum 2012; 55(1):18-25.

Camilleri 2008

Camilleri M, Kerstens R, Rykx A, Vandeplassche L. A placebo-controlled trial of prucalopride for severe chronic constipation. The New England Journal of Medicine 2008; 358(22):2344-54.

\section{Carr 2013}

Carr LK, Robert M, Kultgen PL, Herschorn S, Birch C, Murphy M, et al. Autologous muscle derived cell therapy for stress urinary incontinence: a prospective, dose ranging study. The Journal of Urology 2013;189(2):595-601.

\section{Carrington 2011}

Carrington EV, Knowles $\mathrm{CH}$. The influence of sacral nerve stimulation on anorectal dysfunction. Colorectal Disease 2011;13(Suppl 2):5-9.

\section{Carrington 2014}

Carrington EV, Evers J, Grossi U, Dinning PG, Scott SM, O'Connell PR, et al. A systematic review of sacral nerve stimulation mechanisms in the treatment of fecal incontinence and constipation. Neurogastroenterology \& Motility 2014;26(9):1222-37.

\section{Cook 2009}

Cook IJ, Talley NJ, Benninga MA, Rao SS, Scott SM. Chronic constipation: overview and challenges. Neurogastroenterology \& Motility 2009;21 (Suppl 2):1-8.

Dinning 2012

Dinning PG, Hunt LM, Arkwright JW, Patton V, Szczesniak MM, Wiklendt L, et al. Pancolonic motor response to subsensory and suprasensory sacral nerve stimulation in 
patients with slow-transit constipation. British Journal of Surgery 2012;99(7):1002-10.

\section{Dudding 2008}

Dudding TC, Meng Lee E, Faiz O, Pares D, Vaizey CJ, McGuire A, et al. Economic evaluation of sacral nerve stimulation for faecal incontinence. The British Journal of Surgery 2008;95(9):1155-63.

\section{Duelund-Jakobsen 2013}

Duelund-Jakobsen J, Buntzen S, Lundby L, Laurberg S. Sacral nerve stimulation at subsensory threshold does not compromise treatment efficacy: results from a randomized, blinded crossover study. Annals of Surgery 2013;257(2): 219-23.

Ehrenpreis 2007

Ehrenpreis ED, Chang D, Eichenwald E. Pharmacotherapy for fecal incontinence: a review. Diseases of the Colon \& Rectum 2007;50(5):641-9.

\section{Enck 2009}

Enck P, Van der Voort IR, Klosterhalfen S. Biofeedback therapy in fecal incontinence and constipation. Neurogastroenterology \& Motility 2009;21(11):1133-41.

\section{Evers 2014}

Evers J, Devane L, Carrington EV, Scott SM, Knowles CH, O'Connell PR, et al. Effects of stimulation frequency and intensity in sacral neuromodulation on anorectal inputs to the somatosensory cortex in an experimental model. British Journal of Surgery 2014;101(10):1317-28.

\section{FDA 1998}

Food, Drug Administration. Medtronic, Inc.; premarket approval of the Interstim Sacral Nerve Stimulation (SNS) System--FDA. Notice. Federal register 1998;63(19):4457.

\section{Fraser 2004}

Fraser C, Glazener C, Grant A, Mowatt G. Systematic review of the efficacy and safety of sacral nerve stimulation for faecal incontinence. Available at: http://www.nice.org.uk/ guidance/ipg99/resources/systematic-review-of-theefficacy-and-safety-of-sacral-nerve-stimulation-for-faecalincontinence2 (accessed 12 December 2014) 2004.

\section{Gallegos-Orozco 2012} Gallegos-Orozco JF, Foxx-Orenstein AE, Sterler SM, Stoa JM. Chronic constipation in the elderly. The American Journal of Gastroenterology 2012;107(1):18-25; quiz 26.

\section{Graf 2011}

Graf W, Mellgren A, Matzel KE, Hull T, Johansson C, Bernstein M. Efficacy of dextranomer in stabilised hyaluronic acid for treatment of faecal incontinence: a randomised, sham-controlled trial. Lancet 2011;377(9770): 997-1003.

\section{Griffin 2011}

Griffin KM, Pickering M, O'Herlihy C, O'Connell PR, Jones JF. Sacral nerve stimulation increases activation of the primary somatosensory cortex by anal canal stimulation in an experimental model. British Journal of Surgery 2011;98 (8):1160-9.

\section{Higgins 2011}

Higgins JPT, Green S (editors). Cochrane Handbook for Systematic Reviews of Interventions Version 5.1.0 [updated March 2011]. The Cochrane Collaboration, 2011. Available from www.cochrane-handbook.org.

\section{Holzer 2008}

Holzer B, Rosen HR, Novi G, Ausch C, Hölbling N, Hofmann M, et al. Sacral nerve stimulation in patients with severe constipation. Diseases of the Colon \& Rectum 2008;51 (5):524-29; discussion 529-30.

\section{Hopkinson 1966}

Hopkinson BR, Lightwood R. Electrical treatment of anal incontinence. Lancet 1966;1(7432):297-8.

\section{Hotouras 2014}

Hotouras A, Murphy J, Walsh U, Allison M, Curry A, Williams NS, et al. Outcome of percutaneous tibial nerve stimulation (PTNS) for fecal incontinence: a prospective cohort study. Annals of Surgery 2014;259(5):939-43.

\section{HSCIC 2013}

Health and Social Care Information Centre. Prescriptions Dispensed in the Community: England 2002-12. http:// www.hscic.gov.uk/catalogue/PUB11291/pres-disp-comeng-2002-12-rep.pdf 2013.

\section{Irvine 2002}

Irvine EJ, Ferrazzi S, Pare P, Thompson WG, Rance L. Health-related quality of life in functional GI disorders: focus on constipation and resource utilization. The American Journal of Gastroenterology 2002;97(8):1986-93.

\section{Jarrett 2004}

Jarrett MED, Mowatt G, Glazener CMA, Fraser C, Nicholls RJ, Grant AM, et al. Systematic review of sacral nerve stimulation for faecal incontinence and constipation. British Journal of Surgery 2004;91(12):1559-69.

\section{Johanson 1996}

Johanson JF, Lafferty J. Epidemiology of fecal incontinence: the silent affliction. The American Journal of Gastroenterology 1996;91(1):33-6.

\section{Johanson 2008}

Johanson JF, Morton D, Geenen J, Ueno R. Multicenter, 4week, double-blind, randomized, placebo-controlled trial of lubiprostone, a locally-acting type- 2 chloride channel activator, in patients with chronic constipation. The American Journal of Gastroenterology 2008;103(1):170-7.

\section{Kamm 2010} Kamm MA, Dudding TC, Melenhorst J, Jarrett M, Wang Z, Buntzen S, et al. Sacral nerve stimulation for intractable constipation. Gut 2010;59(3):333-40.

\section{Knowles 1999}

Knowles CH, Scott M, Lunniss PJ. Outcome of colectomy for slow transit constipation. Annals of Surgery 1999;230 (5):627-38

\section{Knowles 2003}

Knowles CH, Scott SM, Rayner C, Glia A, Lindberg G, Kamm MA, et al. Idiopathic slow-transit constipation: an 
almost exclusively female disorder. Diseases of the Colon \& Rectum 2003;46(12):1716-7.

\section{Knowles 2009}

Knowles CH, Dinning PG, Pescatori M, Rintala

$\mathrm{R}$, Rosen H. Surgical management of constipation. Neurogastroenterology \& Motility 2009;21(Suppl 2):62-71.

\section{Lehur 1998}

Lehur PA, Glemain P, Bruley des Varannes S, Buzelin JM, Leborgne J. Outcome of patients with an implanted artificial anal sphincter for severe faecal incontinence. A single institution report. International Journal of Colorectal Disease 1998;13(2):88-92.

Lehur 2010

Lehur PA, McNevin S, Buntzen S, Mellgren AF, Laurberg S, Madoff RD. Magnetic anal sphincter augmentation for the treatment of fecal incontinence: a preliminary report from a feasibility study. Diseases of the Colon \& Rectum 2010;53 (12):1604-10.

\section{Lunniss 2004}

Lunniss PJ, Gladman MA, Hetzer FH, Williams NS, Scott SM. Risk factors in acquired faecal incontinence. Journal of the Royal Society of Medicine 2004;97(3):111-6.

\section{MacDonagh 1990}

MacDonagh RP, Sun WM, Smallwood R, Forster D, Read NW. Control of defecation in patients with spinal injuries by stimulation of sacral anterior nerve roots. British Medical Journal 1990;300(6738):1494-7.

\section{Maeda 2010}

Maeda Y, Lundby L, Buntzen S, Laurberg S. Sacral nerve stimulation for constipation: suboptimal outcome and adverse events. Diseases of the Colon \& Rectum 2010;53(7): 995-9.

\section{Malouf 2000}

Malouf AJ, Norton CS, Engel AF, Nicholls RJ, Kamm MA. Long-term results of overlapping anterior anal-sphincter repair for obstetric trauma. Lancet 2000;355(9200):260-5.

\section{Matzel 1990}

Matzel KE, Schmidt RA, Tanagho EA. Neuroanatomy of the striated muscular anal continence mechanism. Implication for the use of neurostimulation. Diseases of the Colon \& Rectum 1990;33:666-673.

\section{Matzel 1995}

Matzel KE, Stadelmaier U, Hohenfellner M, Gall FP. Electrical stimulation of sacral spinal nerves for treatment of faecal incontinence. Lancet 1995;346(8983):1124-7.

\section{McCrea 2009}

McCrea GL, Miaskowski C, Stotts NA, Macera L, Paul SM, Varma MG. Gender differences in self-reported constipation characteristics, symptoms, and bowel and dietary habits among patients attending a specialty clinic for constipation. Gender Medicine 2009;6(1):259-71.

\section{Melenhorst 2007}

Melenhorst J, Koch SM, Uludag O, van Gemert WG, Baeten CG. Sacral neuromodulation in patients with faecal incontinence: results of the first 100 permanent implantations. Colorectal Disease 2007;9(8):725-30.

\section{Mitchell 2011}

Mitchell PJ, Cattle K, Saravanathan S, Telford KJ, Kiff ES Insertion under local anaesthetic of temporary electrodes for sacral nerve stimulation testing is reliable and cost effective. Colorectal Disease 2011;13(4):445-8.

\section{Mugie 2011}

Mugie SM, Benninga MA, Di Lorenzo C. Epidemiology of constipation in children and adults: a systematic review. Best Practice \& Research: Clinical Gastroenterology 2011;25 (1):3-18.

\section{Nelson 1998}

Nelson R, Furner S, Jesudason V. Fecal incontinence in Wisconsin nursing homes: prevalence and associations. Diseases of the Colon \& Rectum 1998;41(10):1226-9.

\section{Nelson 2004}

Nelson RL. Epidemiology of fecal incontinence. Gastroenterology 2004;126(1 Suppl1):S3-7.

\section{NHS 2012}

National Health Service. Constipation - suspected. http://healthguides.mapofmedicine.com/choices/map/ constipation 'in 'adults' and the elderly1.html 2012.

\section{NHS 2013}

National Health Service (NHS) England. A08/S/d 2013/14 NHS standard contract for colorectal: faecal incontinence (adult). Available at: http://www.england.nhs.uk/ wp-content/uploads/2013/06/a08-colore-faecal-inconadult.pdf (accessed 21 May 2014) 2013:1-7.

NICE 2007

National Institute for Health and Care Excellence. Faecal incontinence: The management of faecal incontinence in adults. http://www.nice.org.uk/nicemedia/live/11012/ 36582/36582.pdf 2007.

\section{Norton 2003}

Norton C, Chelvanayagam S, Wilson-Barnett J, Redfern S, Kamm MA. Randomized controlled trial of biofeedback for fecal incontinence. Gastroenterology 2003;125(5):1320-9.

\section{Norton 2004}

Norton C. Behavioral management of fecal incontinence in adults. Gastroenterology 2004;126(1 Suppl 1):S64-70.

\section{Norton 2006}

Norton C. Constipation in older patients: effects on quality of life. British Journal of Nursing 2006;15(4):188-92.

Norton 2007

Norton C, Thomas L, Hill J. Management of faecal incontinence in adults: summary of NICE guidance. British Medical Journal 2007;334(7608):1370-1.

\section{Omar 2013}

Omar MI, Edwin C. Drug treatment for faecal incontinence in adults. Cochrane Database of Systematic Reviews 2013, Issue 6. [DOI: 10.1002/14651858.CD002116.pub2]

Otto 2010

Otto SD, Burmeister S, Buhr HJ, Kroesen A. Sacral nerve stimulation induces changes in the pelvic floor and rectum 
that improve continence and quality of life. Journal of Gastrointestinal Surgery 2010;14(4):636-44.

\section{Patton 2013}

Patton V, Wiklendt L, Arkwright JW, Lubowski DZ,

Dinning PG. The effect of sacral nerve stimulation on distal colonic motility in patients with faecal incontinence. British Journal of Surgery 2013;100(7):959-68.

Peery 2012

Peery AF, Dellon ES, Lund J, Crockett SD, McGowan CE, Bulsiewicz WJ, et al. Burden of gastrointestinal disease in the United States: 2012 update. Gastroenterology 2012;143 (5):1179-87 e1-3.

\section{Poulton 1999}

Poulton B, Thomas S. The Nursing Cost of Constipation. Primary Health Care 1999;9(9):17-22.

\section{Probert 1995}

Probert CS, Emmett PM, Heaton KW. Some determinants of whole-gut transit time: a population-based study. QJM 1995;88(5):311-5.

\section{Rao 2004a}

Rao SS. Pathophysiology of adult fecal incontinence. Gastroenterology 2004;126(1 Suppl1):S14-22.

\section{Rao 2004b}

Rao SS. Diagnosis and management of fecal incontinence. American College of Gastroenterology Practice Parameters Committee. The American Journal of Gastroenterology 2004; 99(8):1585-604.

\section{Ratto 2011}

Ratto C, Parello A, Donisi L, Litta F, De Simone V, Spazzafumo L, et al. Novel bulking agent for faecal incontinence. The British Journal of Surgery 2011;98(11): 1644-52.

\section{Reference Manager 2012}

Thomson Reuters. Reference Manager Professional Edition Version 12. New York: Thomson Reuters, 2012.

\section{Scott 2011}

Scott SM, van den Berg MM, Benninga MA. Rectal sensorimotor dysfunction in constipation. Best Practice \& Research: Clinical Gastroenterology 2011;25(1):103-18.

\section{Sharma 2013}

Sharma A, Bussen D, Herold A, Jayne D. Review of Sacral Neuromodulation for Management of Constipation. Surgical Innovation 2013;20(6):614-624.

\section{Sonnenberg 1989}

Sonnenberg A, Koch TR. Epidemiology of constipation in the United States. Diseases of the Colon \& Rectum 1989;32 (1): $1-8$.

\section{Stewart 1999}

Stewart WF, Liberman JN, Sandler RS, Woods MS, Stemhagen A, Chee E, et al. Epidemiology of constipation (EPOC) study in the United States: relation of clinical subtypes to sociodemographic features. The American Journal of Gastroenterology 1999;94(12):3530-40.

\section{Sultan 1993}

Sultan AH, Kamm MA, Hudson CN, Thomas JM, Bartram CI. Anal-sphincter disruption during vaginal delivery. The New England Journal of Medicine 1993;329(26):1905-11.

\section{Sultan 1997a}

Sultan AH, Kamm MA. Faecal incontinence after childbirth. British Journal of Obstetrics and Gynaecology 1997;104(9): 979-82.

\section{Sultan 1997b}

Sultan AH, Monga AK. Anal and urinary incontinence in women with obstetric anal sphincter rupture. British Journal of Obstetrics and Gynaecology 1997;104(6):754-5.

Tan 2011

Tan E, Ngo NT, Darzi A, Shenouda M, Tekkis PP. Metaanalysis: sacral nerve stimulation versus conservative therapy in the treatment of faecal incontinence. International Journal of Colorectal Disease 2011;26:275-94.

\section{Tanagho 1989}

Tanagho EA, Schmidt RA, Orvis BR. Neural stimulation for control of voiding dysfunction: a preliminary report in 22 patients with serious neuropathic voiding disorders. The Journal of Urology 1989;142(2 Pt 1):340-5.

Thin 2013

Thin NN, Horrocks EJ, Hotouras A, Palit S, Thaha MA, Chan CL, et al. Systematic review of the clinical effectiveness of neuromodulation in the treatment of faecal incontinence. The British Journal of Surgery 2013;100(11): $1430-47$.

\section{Tjandra 2004}

Tjandra JJ, Lim JF, Matzel K. Sacral nerve stimulation: an emerging treatment for faecal incontinence. ANZ Journal of Surgery 2004;74(12):1098-106.

\section{Vaizey 2014}

Vaizey CJ. Faecal incontinence: standardizing outcome measures. Colorectal Disease 2014;16(3):156-8.

van den Berg 2006

van den Berg MM, Benninga MA, Di Lorenzo C. Epidemiology of childhood constipation: a systematic review. The American Journal of Gastroenterology 2006;101 (10):2401-9.

\section{Vitton 2009}

Vitton V, Roman S, Damon H, Barth X, Mion F. Sacral nerve stimulation and constipation: still a long way to go Diseases of the Colon \& Rectum 2009;52(4):752-3; author reply 753-4.

\section{Wald 2008}

Wald A, Scarpignato C, Mueller-Lissner S, Kamm MA, Hinkel U, Helfrich I, et al. A multinational survey of prevalence and patterns of laxative use among adults with self-defined constipation. Alimentary Pharmacology \& Therapeutics 2008;28(7):917-30.

\section{Wexner 2010}

Wexner SD, Coller JA, Devroede G, Hull T, McCallum $\mathrm{R}$, Chan M, et al. Sacral nerve stimulation for fecal 
incontinence: results of a 120-patient prospective

multicenter study. Annals of Surgery 2010;251(3):441-9.

\section{Whitehead 2009}

Whitehead WE, Borrud L, Goode PS, Meikle S, Mueller ER, Tuteja A, et al. Fecal incontinence in US adults: epidemiology and risk factors. Gastroenterology 2009;137 (2):512-7, 517 e1-2.

Wong 2011

Wong MT, Meurette G, Rodat F, Regenet N, Wyart V, Lehur PA. Outcome and management of patients in whom sacral nerve stimulation for fecal incontinence failed. Diseases of the Colon \& Rectum 2011;54(4):425-32.

\section{Woodward 2014}

Woodward S, Norton C, Chiarelli P. Biofeedback for treatment of chronic idiopathic constipation in adults. Cochrane Database of Systematic Reviews 2014, Issue 3. [DOI: 10.1002/14651858.CD008486.pub2]

\section{References to other published versions of this review}

\section{Mowatt 2007}

Mowatt G, Glazener C, Jarrett M. Sacral nerve stimulation for faecal incontinence and constipation in adults. Cochrane Database of Systematic Reviews 2007, Issue 3. [DOI: 10.1002/14651858.CD004464.pub2]

* Indicates the major publication for the study 


\title{
CHARACTERISTICS OF STUDIES
}

\section{Characteristics of included studies [ordered by study ID]}

\author{
Dinning 2015\#
}

Methods
Randomised crossover trial

Blinding: participant and investigator.

Follow-up: 3 weeks (long-term follow-up not reported)

Setting: two centres in Sydney, Australia.

Intention-to-treat analysis: yes

Withdrawals: 6 participants
Participants
Enrolled: 59

Median age (range): 42 (19 to 74 )

Gender: male (4); female (55).

Duration of symptoms: constipation > 10 years (43), 5 to 10 years (7), and 2 to 5 years (9)

Received permanent implant: 55

Lost to follow-up: 2

Inclusion criteria:

All of the following: i) A complete bowel movement on less than 3 days per week, for at least 2 of 3 weeks of the surveillance phase (determined from daily stool diaries). ii) Aged 18 to 75 yrs; iii) Scintigraphically confirmed slow colonic transit defined as colonic isotope retention $>20 \%$ at 96 h (laboratory upper limit of normal $=1 \%$ at $96 \mathrm{~h}$; iv) Normal anorectal manometry, with no evidence of dyssynergia and confirmed ability to expel rectal balloon; v) With no radiographic evidence of functional (e.g. pelvic floor dyssynergia) or anatomical (e.g. significant rectocele with retention of contrast, occluding intussusception) impediment to the expulsion of the radio-opaque contrast; vi) Failed symptomatic response to standard therapies including osmotic agents, faecal emollients, laxatives, dietary modification and exercise; and vii) A normal colonoscopy within 5 years

Exclusion criteria:

Any one of the following; i) Metabolic, neurogenic or endocrine disorder(s) known to cause constipation; ii) Drugs listing constipation as a potential side effect; or iii) NonEnglish speaker or an inability to provide informed consent

Any one of the following; i) Prior abdominal radiotherapy; ii) Prior abdominal surgery (except cholecystectomy, appendicectomy, inguinal hernia repair, splenectomy, fundoplication; oophorectomy or hysterectomy); iii) Current or planned pregnancy; iv) Comorbidity considered to put the patient at risk from surgical electrode implantation; or v) History of malignancy

Interventions

All participants underwent peripheral nerve evaluation. Then participants received permanent electrode implantation Intervention: 'suprasensory' stimulation for 3 weeks Control: Sham stimulator off for 3 weeks.

Wash out period: 2 weeks. 


\section{Dinning 2015\# (Continued)}

\begin{tabular}{|c|c|c|}
\hline Outcomes & \multicolumn{2}{|c|}{$\begin{array}{l}\text { Bowel diary (stool frequency per week; bowel motion per week; feeling of complete } \\
\text { evacuation per week; straining per week; laxative free days per week; soft stool per week; } \\
\text { normal stool per week; hard stool per week; pain score weekly average; bloating score } \\
\text { weekly average; weekly global satisfaction score; weekly bothersome score). Quality of } \\
\text { life SF-36 }\end{array}$} \\
\hline \multicolumn{3}{|l|}{ Notes } \\
\hline \multicolumn{3}{|l|}{ Risk of bias } \\
\hline Bias & Authors' judgement & Support for judgement \\
\hline $\begin{array}{l}\text { Random sequence generation (selection } \\
\text { bias) }\end{array}$ & Low risk & $\begin{array}{l}\text { Utilised an off-site NHMRC clinical trials } \\
\text { centre automated phone link }\end{array}$ \\
\hline Allocation concealment (selection bias) & Low risk & $\begin{array}{l}\text { Utilised an off-site NHMRC clinical trials } \\
\text { centre automated phone link }\end{array}$ \\
\hline $\begin{array}{l}\text { Blinding of participants and personnel } \\
\text { (performance bias) } \\
\text { All outcomes }\end{array}$ & Low risk & Participants and personnel blinded. \\
\hline $\begin{array}{l}\text { Blinding of outcome assessment (detection } \\
\text { bias) } \\
\text { All outcomes }\end{array}$ & Low risk & Investigator blinded. \\
\hline $\begin{array}{l}\text { Incomplete outcome data (attrition bias) } \\
\text { All outcomes }\end{array}$ & Unclear risk & $\begin{array}{l}\text { Out of the } 59 \text { participants enrolled, } 6 \text { with- } \\
\text { drew. The reasons for discontinuation were } \\
\text { depression }(n=1) \text {, too far to travel }(n=2) \text {, } \\
\text { could not commit }(n=1) \text {, pregnancy }(n= \\
\text { 1) and severe wound infection }(n=1)\end{array}$ \\
\hline Selective reporting (reporting bias) & Low risk & All outcomes reported. \\
\hline Other bias & Low risk & None identified \\
\hline
\end{tabular}

Kahlke 2015\#

Methods

Participants
Randomised crossover trial

Blinding: participant and investigator. Sequence generation by random number table

Follow-up: 3 months

Setting: single-centre, Germany

Withdrawals: 2 participants

Intention-to-treat analysis: no

Enrolled: 16

Median age (SD): 55.5 (11.8)

Gender: female (16) 
Kahlke 2015\# (Continued)

Duration of symptoms: mean (SD): 51.9 (42.7)

Received permanent implant: 16

Lost to follow-up: 0

Inclusion criteria: not mentioned

Exclusion criteria: not mentioned

Interventions

All patients had sacral nerve modulation through a staged implantation procedure between 2009 and 2011. After 26.8 months (median) following implantation 16 out of the 31 participants agreed to be randomised into a crossover design to stimulation $\mathrm{ON}$ or OFF, each period lasted for 3 weeks. After 6 weeks (i.e. the two periods) participants while blinded selected the preferred period (ON or OFF) which was continued for a further 3 months. There was no treatment-free interval

Outcomes

Frequency of bowel movements, frequency of faecal incontinence, Cleveland Clinic Incontinence Score (CCIS)

Notes

Risk of bias

Bias

Authors' judgement

Support for judgement

Random sequence generation (selection Low risk

Random number table utilised.

bias)

\begin{tabular}{llll} 
Allocation concealment (selection bias) & Unclear risk & Unclear 'Randomised crossover study'. \\
\hline $\begin{array}{l}\text { Blinding of participants and personnel } \\
\text { (performance bias) } \\
\text { All outcomes }\end{array}$ & Low risk & $\begin{array}{l}\text { Participants and key study personnel } \\
\text { blinded. }\end{array}$ \\
\hline
\end{tabular}

Blinding of outcome assessment (detection Low risk

Personnel assessing outcome were blinded.

bias)

All outcomes

Incomplete outcome data (attrition bias) Unclear risk

All outcomes

Out of the 16 participants enrolled, 2 discontinued; the reasons cited were participant turned stimulator $\mathrm{ON}$ with handheld device because she had become completey incontinent $(\mathrm{n}=1)$; participant fell on lower back leading to breakage of permanent lead $(\mathrm{n}=1)$

\begin{tabular}{l|l|l}
\hline Selective reporting (reporting bias) & Low risk & All outcomes reported
\end{tabular}

\begin{tabular}{lll}
\hline Other bias & Low risk & None identified. \\
\hline
\end{tabular}


Methods

Randomised crossover trial

Blinding: participant and investigator

Follow-up: the study consisted of two 2-week intervals with subsensory stimulation either 'on' or 'off'

Setting: single centre UK

Withdrawals: none

Intention-to-treat analysis: yes

\begin{tabular}{ll} 
Participants & Enrolled: 2 \\
& Age: both aged 36 \\
& Gender: female (2) \\
& Duration of symptoms: not stated \\
& Received permanent implant: 2 \\
& Inclusion criteria: failed maximal conservative treatment; psychologically stable; normal \\
& sigmoidoscopy; prolonged whole gut transit time; delayed evacuation \\
& Exclusion criteria: not stated \\
\hline
\end{tabular}

Interventions

Both participants had a successful 3-week trial of percutaneous stimulation before onestage permanent implantation of a stimulator to the $\mathrm{S} 3$ foramen

A Intervention: stimulator On for two weeks with subsensory stimulation

B Control: stimulator Off

No treatment-free period between the weeks

Outcomes

Bowel frequency (per 2 weeks); time with pain and bloating (\%); Wexner constipation score (0 to 30); Symptom analogue score (0 to 100$)$; anal manometry

Notes

Risk of bias

\begin{tabular}{l|l|l} 
Bias & Authors' judgement & Support for judgement \\
\hline $\begin{array}{l}\text { Random sequence generation (selection } \\
\text { bias) }\end{array}$ & Unclear risk & Unclear: 'Randomised crossover trial'. \\
\hline $\begin{array}{l}\text { Allocation concealment (selection bias) } \\
\text { Blinding of participants and personnel } \\
\text { (performance bias) } \\
\text { All outcomes }\end{array}$ & Low risk & Unclear: 'Randomised crossover trial'. \\
\hline $\begin{array}{l}\text { Blinding of outcome assessment (detection } \\
\text { bias) } \\
\text { All outcomes }\end{array}$ & Low risk & Participants blinded. \\
\hline $\begin{array}{l}\text { Incomplete outcome data (attrition bias) } \\
\text { All outcomes }\end{array}$ & Low risk & Outcome assessor blinded. \\
\hline & & $\begin{array}{l}\text { Results were reported for everyone who en- } \\
\text { tered the studies and the participants were } \\
\text { analysed in the groups to which they were } \\
\text { originally allocated, effectively resulting in } \\
\text { an intention-to-treat analysis }\end{array}$ \\
\hline
\end{tabular}


Kenefick 2002\# (Continued)

\begin{tabular}{|c|c|c|}
\hline Selective reporting (reporting bias) & Unclear risk & $\begin{array}{l}\text { The results of the Short Form } 36 \text { quality } \\
\text { of life questionnaire were not reported in } \\
\text { results table }\end{array}$ \\
\hline Other bias & Low risk & None identified. \\
\hline
\end{tabular}

Leroi 2005\#

Methods
Participants

Randomised crossover trial

Blinding: participant and investigator. Sequence generation by random number table.

Follow-up: 3 months

Setting: multicentre, France

Intention-to-treat analysis: no

\section{Enrolled: 34}

Median age (range): 57 (33 to 73)

Gender: male (3); female (31).

Duration of symptoms: < 1 yr (12); 1 to 5 years (12); 5 to 10 years (4); > 10 years (6)

Received permanent implant: 27

Lost to follow-up: 3

Inclusion criteria: faecal incontinence to solid or liquid stool or incapacitating urgency; failed conservative treatment; demonstrable unilateral bulbo- (or clitorido-) cavernosus reflex; informed consent given. Participants with external anal sphincter damage on ultrasound were included in the study if the defect was not considered to be the main cause of faecal incontinence (i.e. limited defect, $\geq$ than $30^{\circ}$ or limited to one part, superficial, middle, or deep part of the external anal sphincter).

Exclusion criteria: extensive external anal sphincter defect (defect that was considered to be the main cause of faecal incontinence)

Interventions

Before permanent implantation, participants underwent temporary stimulation, either percutaneously-placed test stimulation lead (Medtronic InterStim 3057) or permanent quadripolar lead (model 3093). Both types of leads were connected to an external pulse generator (model 3625). All participants were tested for 8 to 15 days

For permanent implantation, participants with temporary test stimulation lead underwent simultaneous implantation of the quadripolar lead and the pulse generator; those with a lead already in place underwent removal of the percutaneous extension (model 3095) before placement of the pulse generator (model 3023) subcutaneously, below the superficial fascia, in the upper parts of buttocks ipsilateral to the permanent electrode. The lead contained four contact electrodes. The electrode combination which allowed the participant to have the best perception of the perineum muscle and anal sphincter contraction was chosen for permanent stimulation. Stimulation was continuous with a pulse width of 210 microseconds, a frequency of 14 pulses per second, and a current amplitude adapted to the participant's perception of perineal and anal sphincter muscle contraction. The stimulator was left on during defaecation and urinary voiding. After a 1- to 3-month optimisation 'on' phase, participants were randomised to:

A Intervention: stimulation 'on' for 1 month or

B Control: stimulation 'off' for 1 month, then crossed over to the alternative 
No treatment-free interval

At the end of the second month, the preferred period ('on' or 'off') was continued for a further 3 months: if neither was preferred, the stimulator was turned on

Outcomes

Episodes of faecal incontinence; faecal urgency; delay in postponing defaecation; bowel movements; severity of incontinence; quality of life; anal manometry

Notes

Severity of incontinence was graded by the Cleveland Clinic Incontinence Scoring System. The score ranged from 0 (normal continence) to 20 (maximum incontinence). Quality of life was assessed with the French version of the American Society of Colon and Rectal Surgeons' Fecal Incontinence Quality of Life Questionnaire (FIQL). In the questionnaire, four separate QOL domains were explored: lifestyle; coping/behaviour; depression/self-perception; and embarrassment

\section{Risk of bias}

\begin{tabular}{|c|c|c|}
\hline Bias & Authors' judgement & Support for judgement \\
\hline $\begin{array}{l}\text { Random sequence generation (selection } \\
\text { bias) }\end{array}$ & Low risk & Random number tables. \\
\hline Allocation concealment (selection bias) & Unclear risk & Unclear 'Randomised crossover trial'. \\
\hline $\begin{array}{l}\text { Blinding of participants and personnel } \\
\text { (performance bias) } \\
\text { All outcomes }\end{array}$ & Low risk & $\begin{array}{l}\text { Participants were blinded to treatment al- } \\
\text { located. }\end{array}$ \\
\hline $\begin{array}{l}\text { Blinding of outcome assessment (detection } \\
\text { bias) } \\
\text { All outcomes }\end{array}$ & Low risk & Personnel assessing outcome were blinded. \\
\hline $\begin{array}{l}\text { Incomplete outcome data (attrition bias) } \\
\text { All outcomes }\end{array}$ & Unclear risk & $\begin{array}{l}\text { Out of the } 34 \text { participants enrolled, } 10 \text { pre- } \\
\text { maturely discontinued. The reasons for dis- } \\
\text { continuation were device-related adverse } \\
\text { events }(n=4) \text {, protocol violation }(n=3) \\
\text {, insufficient therapeutic response }(n=1) \text {, } \\
\text { no return to follow-up }(n=1) \text {, and adverse } \\
\text { event (stroke) not related to SNS }(n=1)\end{array}$ \\
\hline Selective reporting (reporting bias) & Low risk & All outcomes reported. \\
\hline Other bias & Low risk & None identified \\
\hline
\end{tabular}




\begin{tabular}{|c|c|c|}
\hline Methods & \multicolumn{2}{|c|}{$\begin{array}{l}\text { Randomised crossover trial } \\
\text { Blinding: participant and investigator } \\
\text { Follow-up: } 2 \text { weeks } \\
\text { Setting: single centre, Denmark } \\
\text { Intention-to-treat analysis: no }\end{array}$} \\
\hline Participants & \multicolumn{2}{|c|}{$\begin{array}{l}\text { Enrolled: } 7 \\
\text { Age: } 67 \text { years ( } 60 \text { to } 87) \\
\text { Gender: male (1); female (6). } \\
\text { Duration of symptoms: not stated } \\
\text { Inclusion criteria: not stated } \\
\text { Exclusion criteria: not stated }\end{array}$} \\
\hline Interventions & \multicolumn{2}{|c|}{$\begin{array}{l}\text { Sacral nerve stimulation } \\
\text { A Intervention: stimulator 'on' for one week } \\
\text { B Control: stimulator 'off' for one week } \\
\text { No treatment-free period between the weeks }\end{array}$} \\
\hline Outcomes & \multicolumn{2}{|c|}{$\begin{array}{l}\text { Defaecations/week; faecal incontinence episodes/week; urge episodes/week; passive leak- } \\
\text { age/week; soiling/week; anal manometry }\end{array}$} \\
\hline \multicolumn{3}{|l|}{ Notes } \\
\hline \multicolumn{3}{|l|}{ Risk of bias } \\
\hline Bias & Authors' judgement & Support for judgement \\
\hline $\begin{array}{l}\text { Random sequence generation (selection } \\
\text { bias) }\end{array}$ & Unclear risk & 'shuffling envelopes' \\
\hline Allocation concealment (selection bias) & Unclear risk & 'shuffling envelopes' \\
\hline $\begin{array}{l}\text { Blinding of participants and personnel } \\
\text { (performance bias) } \\
\text { All outcomes }\end{array}$ & Low risk & Participants and personnel blinded \\
\hline $\begin{array}{l}\text { Blinding of outcome assessment (detection } \\
\text { bias) } \\
\text { All outcomes }\end{array}$ & Low risk & Examiners blinded \\
\hline $\begin{array}{l}\text { Incomplete outcome data (attrition bias) } \\
\text { All outcomes }\end{array}$ & Low risk & No withdrawals \\
\hline Selective reporting (reporting bias) & Unclear risk & No information \\
\hline Other bias & Low risk & None identified \\
\hline
\end{tabular}


Methods
Randomised parallel-arm

Blinding: Investigator

Follow-up: 6 months

Setting: two centres, London, UK

Intention-to-treat analysis: yes

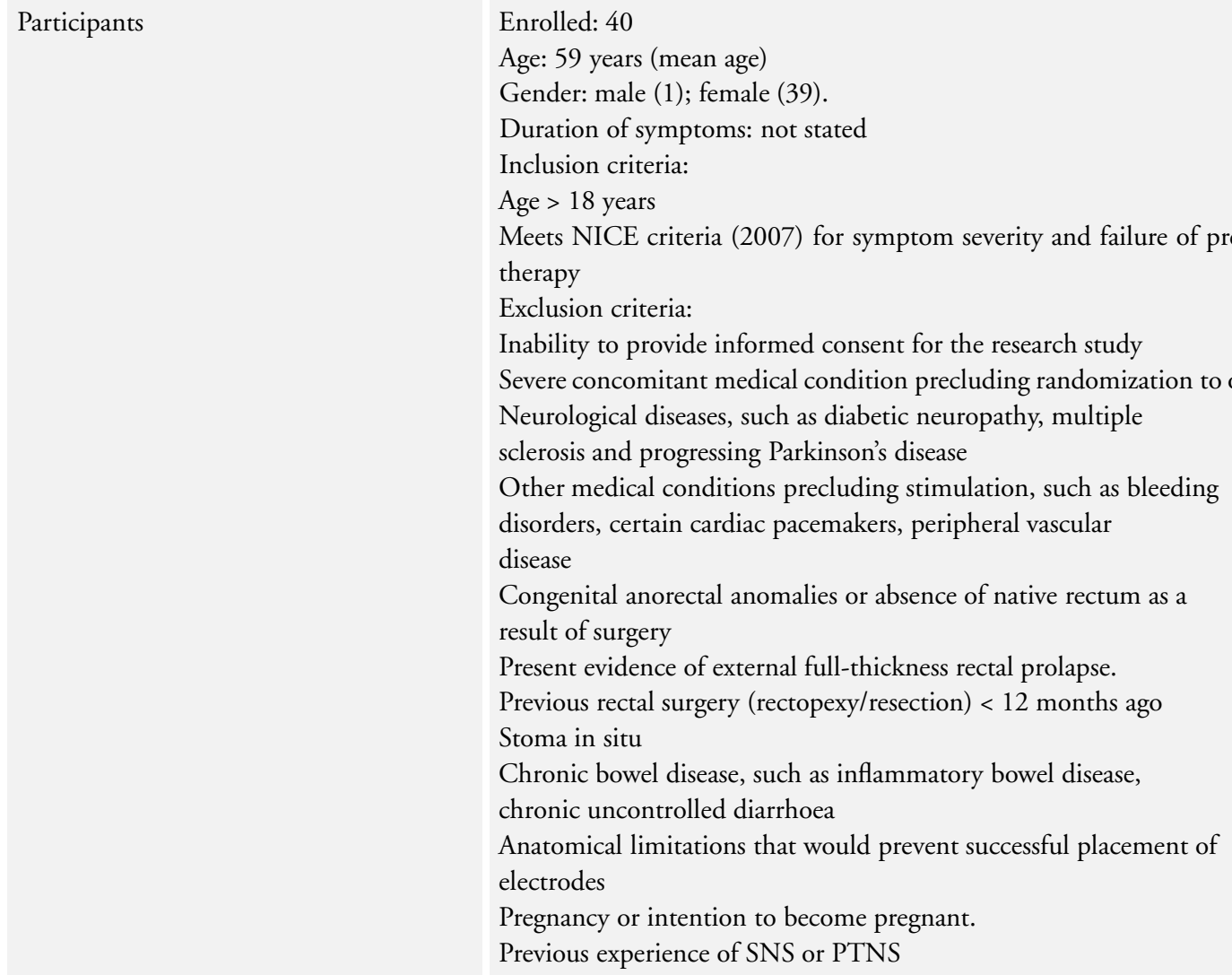

\section{Risk of bias}

\begin{tabular}{lll}
\hline Bias & Authors' judgement & Support for judgement
\end{tabular}

Random sequence generation (selection Low risk bias)
Randomization sequence generated remotely by a statistician uninvolved in recruitment, and requests were made and ac- 
Thin 2015 (Continued)

tioned by e-mail

\begin{tabular}{|c|c|c|}
\hline Allocation concealment (selection bias) & Low risk & $\begin{array}{l}\text { Randomization sequence generated re- } \\
\text { motely by a statistician uninvolved in re- } \\
\text { cruitment, and requests were made and ac- } \\
\text { tioned by e-mail }\end{array}$ \\
\hline $\begin{array}{l}\text { Blinding of participants and personnel } \\
\text { (performance bias) } \\
\text { All outcomes }\end{array}$ & Unclear risk & $\begin{array}{l}\text { Investigator blinded but unclear whether } \\
\text { patients were blinded }\end{array}$ \\
\hline $\begin{array}{l}\text { Blinding of outcome assessment (detection } \\
\text { bias) } \\
\text { All outcomes }\end{array}$ & Unclear risk & $\begin{array}{l}\text { Investigator blinded but unclear whether } \\
\text { patients were blinded }\end{array}$ \\
\hline $\begin{array}{l}\text { Incomplete outcome data (attrition bias) } \\
\text { All outcomes }\end{array}$ & Unclear risk & $\begin{array}{l}\text { Out of } 23 \text { participants randomised to the } \\
\text { SNS group, } 4 \text { withdrew prior to interven- } \\
\text { tion (intercurrent disease } \mathrm{n}=1 \text {; symptoms } \\
\text { resolved } \mathrm{n}=1 \text {; declined further participa- } \\
\text { tion } \mathrm{n}=2 \text { ). Then a further } 3 \text { participants } \\
\text { failed temporary SNS. Another participant } \\
\text { who passed the temporary SNS withdrew } \\
\text { from treatment owing to urgent investiga- } \\
\text { tion for new pararectal cyst. Moreover, in } \\
\text { the PTNS group } 1 \text { participant withdrew } \\
\text { before intervention (symptoms resolved) }\end{array}$ \\
\hline Selective reporting (reporting bias) & Low risk & $\begin{array}{l}\text { Pre-specified outcomes in study protocol } \\
\text { reported. }\end{array}$ \\
\hline Other bias & Low risk & None identified \\
\hline
\end{tabular}

Tjandra 2008

\begin{tabular}{ll} 
Methods & Randomised controlled trial, parallel groups \\
& Blinding: no \\
& Follow-up: 12 months \\
& Withdrawals: 7 \\
& Setting: single centre, Australia \\
& Intention-to-treat analysis: no \\
\hline Participants & Enrolled: 120 \\
& Age: $63.9( \pm 13.2)$ in SNS group. $63( \pm 12.1)$ in the control group. \\
& Gender: male $(9)$; female $(111)$. \\
& Duration of symptoms: not mentioned \\
& Received permanent implant: 53 \\
& Lost to follow-up: none \\
& Inclusion criteria: involuntary passage of solid or liquid stool at least once per week;
\end{tabular}


Tjandra 2008 (Continued)

refractory to medical therapy and pelvic floor exercises; and aged 35 to 86 years.

Exclusion criteria: rectal prolapse, inflammatory bowel disease, congenital anorectal malformation, neurologic disorders such as Parkinson's disease, multiple sclerosis, spinal cord injury, stoma in situ, pregnancy, external anal sphincter defect of more than $120^{\circ}$ of the circumference, bleeding diathesis, and mental or physical disability precluding adherence to study protocol

Interventions

A (53): SNS (Peripheral nerve evaluation for at least 7 days; then permanent implantation in participants with $\geq 50 \%$ reduction in faecal incontinence episodes per week or $\geq$ $50 \%$ reduction in number of days with faecal incontinence per week based on the twoweek bowel diary)

B (60): control group (optimal medical therapy). Optimal medical therapy includes bulking agents, pelvic floor exercises with a team of dedicated physiotherapists, and dietary management on fluid and fibre with a team of dieticians

Outcomes

Anorectal physiology, severity of incontinence, two-week bowel diary (number of incontinent episodes per week, days with incontinence per week, days with staining per week and days with pads per week), faecal incontinence quality of life

Continuous data: all mean (SD) $N$

Episodes of faecal incontinence per week at 3 months: A 2.9 (6.3) 53, B 8.1 (14.1) 60

Episodes of faecal incontinence per week at 12 months: A 3.1 (10.1) 53, B 9.4 (11.8) 60

Days with pads per week at 3 months: A 1.6 (2.6) 53, B 3 (3.8) 60

Days with pads per week at 12 months: A 2.2 (3) 53, B 3.2 (3.1) 60

Days with incontinence per week at 3 months: A 1 (1.7) 53, B 2.9 (2.4) 60

Days with incontinence per week at 12 months: A 1 (1.7) 53, B 3.1 (3.1) 60

Days with staining per week at 3 months: A 1.3 (1.7) 53, B 4.5 (2.1) 60

Days with staining per week at 12 months: A 1.4 (2) 53, B 4.5 (2.3) 60

Cleveland Clinic Incontinence Score [higher = worse] at 3 months: A 1.1 (1) 53, B 12.

$1(2.1) 60$

Cleveland Clinic Incontinence Score at 12 months: A 1.2 (1.8)53, B 14.1 (1.9) 60

Quality of Life SF12 [higher = better]:

SF12 Physical at 3 months: A 43.18 (11.68) 53, B 41.5 (9.89) 60

SF12 Physical at 12 months: A 42.22 (9.25) 53, B 40.5 (10.2) 60

SF12 Mental at 3 months: A 50.16 (10.41) 53, B 47.82 (10.66) 60

SF12 Mental at 12 months: A 49.22 (10.88) 53, B 48.22 (10.12) 60

Quality of Life ASCRS Faecal Incontinence Quality of Life Index (FIQL) [higher = better]:

Lifestyle at 3 months: A 3.34 (0.72) 53, B 2.12 (0.91) 60

Lifestyle at 12 months: A3.31 (0.72) 53, B 2.31 (0.89) 60

Coping at 3 months: A 2.87 (0.8) 53, B 1.85 (0.92) 60

Coping at 12 months : A 2.68 (0.87) 53, B $1.86(0.88) 60$

Depression/self perception at 3 months: A $3.31(0.77)$ 53, B $2.68(0.65) 60$

Depression/self perception at 12 months: A 3.25 (0.8) 53, B 2.64 (0.84) 60

Embarrassment at 3 months: A 2.89 (0.85) 53, B 1.7 (0.67) 60

Embarrassment at 12 months: A 2.76 (0.94) 53, B 1.78 (0.61) 60

Anal manometry measures only reported in SNS Group A at 3 months

Ability to defer defecation and worsening of faecal incontinence only reported in SNS

Group A at 3 months

Adverse effects only reported for SNS group: implantation site pain (6\%) particularly

Sacral nerve stimulation for faecal incontinence and constipation in adults (Review) 
Tjandra 2008 (Continued)

in slimmer participants,

seroma $(2 \%)$ which required percutaneous aspiration and excessive tingling in the vaginal region $(9 \%)$.

Notes

Severity of incontinence was assessed by the Wexner's incontinence score. The score ranged from 0 (normal continence) to 20 (maximum incontinence).

Quality of life was assessed using Fecal Incontinence Quality of Life index (FIQL) of The American Society of Colon and Rectal Surgeons; and the standard short form-12 health survey quality of life questionnaire (SF-12)

\section{Risk of bias}

\begin{tabular}{|c|c|c|}
\hline Bias & Authors' judgement & Support for judgement \\
\hline $\begin{array}{l}\text { Random sequence generation (selection } \\
\text { bias) }\end{array}$ & Unclear risk & $\begin{array}{l}\text { Randomisation was performed from the } \\
\text { central registry by using sealed envelopes }\end{array}$ \\
\hline Allocation concealment (selection bias) & Low risk & $\begin{array}{l}\text { Randomisation was performed from the } \\
\text { central registry by using sealed envelopes }\end{array}$ \\
\hline $\begin{array}{l}\text { Blinding of participants and personnel } \\
\text { (performance bias) } \\
\text { All outcomes }\end{array}$ & High risk & $\begin{array}{l}\text { Participants could not be not blinded and } \\
\text { the control group did not have sham stim- } \\
\text { ulation }\end{array}$ \\
\hline $\begin{array}{l}\text { Blinding of outcome assessment (detection } \\
\text { bias) } \\
\text { All outcomes }\end{array}$ & High risk & $\begin{array}{l}\text { Unblinded assessment for both control and } \\
\text { experimental group }\end{array}$ \\
\hline $\begin{array}{l}\text { Incomplete outcome data (attrition bias) } \\
\text { All outcomes }\end{array}$ & Unclear risk & $\begin{array}{l}7 \text { participants in the SNS group stopped } \\
\text { early but have been counted in the denom- } \\
\text { inators }\end{array}$ \\
\hline Selective reporting (reporting bias) & Low risk & Data from all participants reported \\
\hline Other bias & Low risk & None identified \\
\hline
\end{tabular}

Vaizey 2000\#

\begin{tabular}{ll} 
Methods & Randomised crossover trial. \\
& Blinding: participant and investigator. \\
& Follow-up: the study consisted of two 2-week intervals with subsensory stimulation \\
either 'on' or 'off' \\
Setting: single centre, UK \\
Withdrawals: none \\
Intention-to-treat analysis: yes \\
\hline
\end{tabular}

Participants

Enrolled: 2

Age: 65 and 61 years 


\begin{tabular}{|c|c|}
\hline & $\begin{array}{l}\text { Gender: female (2). } \\
\text { Duration of symptoms: } 2.5 \text { years and } 3 \text { years. } \\
\text { Inclusion criteria: passive faecal incontinence; intact external sphincter; informed consent } \\
\text { given } \\
\text { Exclusion criteria: not stated }\end{array}$ \\
\hline Interventions & $\begin{array}{l}\text { To implant the unilateral electrode (Medtronic InterStim model } 3080 \text { ), the sacral nerve } \\
\text { root (usually S3) that produces the maximal anal response was identified via percutaneous } \\
\text { needle stimulation. An incision over the sacrum allows access to the sacral foramen. } \\
\text { The permanent electrode was inserted directly and secured to the sacral periosteum } \\
\text { after checking its correct placement by stimulation. A connecting lead (model 7495) } \\
\text { was then tunnelled to the anterior abdominal wall to be connected to the stimulator. } \\
\text { The Implantable Pulse Generator (model } 3023 \text { ) is programmable using telemetry. The } \\
\text { voltage required for stimulation was between } 0.5 \text { and } 2 \text { volts at a frequency of } 15 \text { pulses } \\
\text { per second and a pulse width of } 210 \mu \text { s } \\
\text { A Intervention: stimulator 'on' for two weeks with subsensory stimulation } \\
\text { B Control: stimulator 'off' for two weeks } \\
\text { No treatment-free period between the weeks }\end{array}$ \\
\hline Outcomes & $\begin{array}{l}\text { Episodes of faecal incontinence for liquid or solid stool; anal manometry; psychological } \\
\text { assessment; quality of life }\end{array}$ \\
\hline Notes & $\begin{array}{l}\text { Quality of life was assessed with the SF-36 instrument, score } 0 \text { (poor) to } 100 \text { (excellent) } \\
\text {, reporting the domains of role-emotional, general health, mental health, bodily pain, } \\
\text { physical functioning, role-physical, social function, and vitality }\end{array}$ \\
\hline
\end{tabular}

Risk of bias

\section{Bias}

Support for judgement

Unclear.

bias)

\begin{tabular}{|c|c|c|}
\hline Allocation concealment (selection bias) & Unclear risk & Unclear. \\
\hline $\begin{array}{l}\text { Blinding of participants and personnel } \\
\text { (performance bias) } \\
\text { All outcomes }\end{array}$ & Low risk & $\begin{array}{l}\text { Participants and outcome assessors were } \\
\text { blinded to the allocation }\end{array}$ \\
\hline
\end{tabular}

Blinding of outcome assessment (detection Low risk bias)

All outcomes

Participants and outcome assessors were blinded to the allocation

Incomplete outcome data (attrition bias) Low risk All outcomes
Results were reported for everyone who entered the studies and the participants were analysed in the groups to which they were originally allocated, effectively resulting in an intention-to-treat analysis 
Vaizey 2000\# (Continued)

\begin{tabular}{l|ll}
\hline Selective reporting (reporting bias) & Unclear risk & $\begin{array}{l}\text { Psychological assessment not reported in } \\
\text { the results. }\end{array}$ \\
\hline Other bias & Low risk & None identified. \\
\hline
\end{tabular}

Characteristics of excluded studies [ordered by study ID]

\begin{tabular}{ll}
\hline Study & Reason for exclusion \\
\hline Dinning 2007 & No comparator used and study is a trial of wave measurements during the temporary stimulation phase \\
\hline Dinning 2013 & $\begin{array}{l}\text { Only reported proportion of participants who satisfied primary outcome measure. Secondary outcomes (pain, } \\
\text { bloating, laxative-free days) and longer term responses of primary outcomes are not available. Author was contacted }\end{array}$ \\
\hline Knowles 2012 & No report on results of permanent SNS stimulation. \\
\hline
\end{tabular}

\section{Characteristics of ongoing studies [ordered by study ID]}

Borjesson 2013

\begin{tabular}{|c|c|}
\hline Trial name or title & Sacral nerve stimulation or anal bulking therapy for faecal incontinence - a comparative study \\
\hline Methods & $\begin{array}{l}\text { Randomised controlled trial, parallel groups } \\
\text { Blinding: unknown } \\
\text { Follow-up: } 12 \text {-months. } \\
\text { Withdrawals: unknown } \\
\text { Setting: multi-centre, Sweden } \\
\text { Intention-to-treat analysis: unknown }\end{array}$ \\
\hline Participants & 100 \\
\hline Interventions & SNS vs. anal bulking therapy \\
\hline Outcomes & $\begin{array}{l}\text { Primary outcomes: proportion of participants responding with }>50 \% \text { reduction in the number of faecal } \\
\text { incontinence episodes compared to baseline, one year after randomisation } \\
\text { Secondary outcomes: change in number of faecal incontinence episodes, change in deferring time, change in } \\
\text { incontinence score, change in quality of life, and adverse events }\end{array}$ \\
\hline Starting date & $01 / 03 / 2013$ \\
\hline Contact information & $\begin{array}{l}\text { Dr Lars Börjesson } \\
\text { lars.g.borjesson@vgregion.se } \\
\text { Sahlgrenska University Hospital }\end{array}$ \\
\hline
\end{tabular}


Borjesson 2013 (Continued)

\begin{tabular}{ll} 
& Department of Surgery \\
& Gothenburg \\
& 41685 \\
& Sweden \\
\hline Notes & Recruitment end date: $01 / 03 / 2015$ \\
\hline
\end{tabular}

\section{Jayne 2014}

\begin{tabular}{|c|c|}
\hline Trial name or title & $\begin{array}{l}\text { SaFaRI: Sacral nerve stimulation versus the FENIX TM magnetic sphincter augmentation for adult faecal } \\
\text { incontinence: a randomised Investigation }\end{array}$ \\
\hline Methods & $\begin{array}{l}\text { Randomised controlled trial, parallel groups } \\
\text { Blinding: unknown } \\
\text { Follow-up: } 2 \text { weeks; } 6,12 \text {, and } 18 \text { months. } \\
\text { Withdrawals: unknown } \\
\text { Setting: multi-centre (at least } 20 \text { centres), UK } \\
\text { Intention-to-treat analysis: yes }\end{array}$ \\
\hline Participants & 350 \\
\hline Interventions & FENIXTM magnetic anal sphincter (MAS) vs. SNS \\
\hline Outcomes & $\begin{array}{l}\text { Primary outcomes: proportion of patients with device in-situ at } 18 \text { months, and proportion of patients } \\
\text { reporting > 50\% improvement in continence scores } \\
\text { Secondary outcomes: complications, quality of life, and cost-effectiveness }\end{array}$ \\
\hline Starting date & $01 / 01 / 2015$ \\
\hline Contact information & $\begin{array}{l}\text { Primary contact: Professor David Jayne. } \\
\text { Julie Croft: safari@leeds.ac.uk }\end{array}$ \\
\hline Notes & Funded by NIHR HTA; co-ordinated by the Clinical Trials Research Unit, University of Leeds \\
\hline
\end{tabular}

\section{Vallance 2014}
Trial name or title Sacral nerve stimulation versus the FENIXTM magnetic anal sphincter for adult faecal incontinence: A randomised investigation $(\mathrm{SaFaRI})$

\begin{tabular}{ll}
\hline Methods & $\begin{array}{l}\text { Randomised controlled trial, parallel groups } \\
\text { Blinding: unknown }\end{array}$ \\
& $\begin{array}{l}\text { Follow-up: 2 weeks; 6, 12, and } 18 \text { months. } \\
\text { Withdrawals: unknown } \\
\text { Setting: multi-centre (at least } 20 \text { centres), UK } \\
\text { Intention-to-treat analysis: yes }\end{array}$ \\
\hline Participants & 350 \\
\hline $\begin{array}{l}\text { Sacral nerve stimulation for faecal incontinence and constipation in adults (Review) } \\
\text { Copyright @ } 2015 \text { The Cochrane Collaboration. Published by John Wiley \& Sons, Ltd. }\end{array}$
\end{tabular}


Vallance 2014 (Continued)

\begin{tabular}{ll}
\hline Interventions & FENIXTM magnetic anal sphincter (MAS) vs. SNS \\
\hline Outcomes & $\begin{array}{l}\text { Primary outcomes: proportion of patients with device in-situ at } 18 \text { months, and proportion of patients } \\
\text { reporting }>50 \% \text { improvement in continence scores } \\
\text { Secondary outcomes: complications, quality of life, and cost-effectiveness }\end{array}$ \\
\hline Starting date & $01 / 01 / 2015$ \\
\hline Contact information & $\begin{array}{l}\text { Primary contact: Professor David Jayne. } \\
\text { Julie Croft: safari@leeds.ac.uk }\end{array}$ \\
\hline Notes & $\begin{array}{l}\text { Funded by NIHR HTA; co-ordinated by the Clinical Trials Research Unit, University of Leeds } \\
\text { ISRCTN16077538 } \\
\text { DOI 10.1186/ISRCTN16077538 } \\
\text { http://www.isrctn.com/ISRCTN16077538 }\end{array}$ \\
\hline
\end{tabular}


DATA ANDANALYSES

Comparison 1. Faecal incontinence: parallel group data SNS vs medical therapy

\begin{tabular}{|c|c|c|c|c|}
\hline Outcome or subgroup title & $\begin{array}{l}\text { No. of } \\
\text { studies }\end{array}$ & $\begin{array}{c}\text { No. of } \\
\text { participants }\end{array}$ & Statistical method & Effect size \\
\hline $\begin{array}{l}1 \text { Episodes of faecal incontinence } \\
\text { per week }\end{array}$ & 1 & & Mean Difference (IV, Fixed, 95\% CI) & Totals not selected \\
\hline 1.1 At 3 months & 1 & & Mean Difference (IV, Fixed, 95\% CI) & $0.0[0.0,0.0]$ \\
\hline 1.2 At 12 months & 1 & & Mean Difference (IV, Fixed, 95\% CI) & $0.0[0.0,0.0]$ \\
\hline 2 Days using pads per week & 1 & & Mean Difference (IV, Fixed, 95\% CI) & Totals not selected \\
\hline 2.1 At 3 months & 1 & & Mean Difference (IV, Fixed, 95\% CI) & $0.0[0.0,0.0]$ \\
\hline 2.2 At 12 months & 1 & & Mean Difference (IV, Fixed, 95\% CI) & $0.0[0.0,0.0]$ \\
\hline 3 Days with incontinence per week & 1 & & Mean Difference (IV, Fixed, 95\% CI) & Totals not selected \\
\hline 3.1 At 3 months & 1 & & Mean Difference (IV, Fixed, 95\% CI) & $0.0[0.0,0.0]$ \\
\hline 3.2 At 12 months & 1 & & Mean Difference (IV, Fixed, 95\% CI) & $0.0[0.0,0.0]$ \\
\hline $\begin{array}{l}4 \text { Days with faecal staining per } \\
\text { week }\end{array}$ & 1 & & Mean Difference (IV, Fixed, 95\% CI) & Totals not selected \\
\hline 4.1 At 3 months & 1 & & Mean Difference (IV, Fixed, 95\% CI) & $0.0[0.0,0.0]$ \\
\hline 4.2 At 12 months & 1 & & Mean Difference (IV, Fixed, 95\% CI) & $0.0[0.0,0.0]$ \\
\hline $\begin{array}{l}5 \text { Cleveland Clinic Incontinence } \\
\text { Score }\end{array}$ & 1 & & Mean Difference (IV, Fixed, 95\% CI) & Totals not selected \\
\hline 5.1 At 3 months & 1 & & Mean Difference (IV, Fixed, 95\% CI) & $0.0[0.0,0.0]$ \\
\hline 5.2 At 12 months & 1 & & Mean Difference (IV, Fixed, 95\% CI) & $0.0[0.0,0.0]$ \\
\hline 6 SF12 Physical & 1 & & Mean Difference (IV, Fixed, 95\% CI) & Totals not selected \\
\hline 6.1 At 3 months & 1 & & Mean Difference (IV, Fixed, 95\% CI) & $0.0[0.0,0.0]$ \\
\hline 6.2 At 12 months & 1 & & Mean Difference (IV, Fixed, 95\% CI) & $0.0[0.0,0.0]$ \\
\hline 7 SF12 Mental & 1 & & Mean Difference (IV, Fixed, 95\% CI) & Totals not selected \\
\hline 7.1 At 3 months & 1 & & Mean Difference (IV, Fixed, 95\% CI) & $0.0[0.0,0.0]$ \\
\hline 7.2 At 12 months & 1 & & Mean Difference (IV, Fixed, 95\% CI) & $0.0[0.0,0.0]$ \\
\hline 8 FIQL Lifestyle & 1 & & Mean Difference (IV, Fixed, 95\% CI) & Totals not selected \\
\hline 8.1 At 3 months & 1 & & Mean Difference (IV, Fixed, 95\% CI) & $0.0[0.0,0.0]$ \\
\hline 8.2 At 12 months & 1 & & Mean Difference (IV, Fixed, 95\% CI) & $0.0[0.0,0.0]$ \\
\hline 9 FIQL Coping/behaviour & 1 & & Mean Difference (IV, Fixed, 95\% CI) & Totals not selected \\
\hline 9.1 At 3 months & 1 & & Mean Difference (IV, Fixed, 95\% CI) & $0.0[0.0,0.0]$ \\
\hline 9.2 At 12 months & 1 & & Mean Difference (IV, Fixed, 95\% CI) & $0.0[0.0,0.0]$ \\
\hline $\begin{array}{l}10 \text { FIQL Depression/self } \\
\text { perception }\end{array}$ & 1 & & Mean Difference (IV, Fixed, 95\% CI) & Totals not selected \\
\hline 10.1 At 3 months & 1 & & Mean Difference (IV, Fixed, 95\% CI) & $0.0[0.0,0.0]$ \\
\hline 10.2 At 12 months & 1 & & Mean Difference (IV, Fixed, 95\% CI) & $0.0[0.0,0.0]$ \\
\hline 11 FIQL Embarrassment & 1 & & Mean Difference (IV, Fixed, 95\% CI) & Totals not selected \\
\hline 11.1 At 3 months & 1 & & Mean Difference (IV, Fixed, 95\% CI) & $0.0[0.0,0.0]$ \\
\hline 11.2 At 12 months & 1 & & Mean Difference (IV, Fixed, 95\% CI) & $0.0[0.0,0.0]$ \\
\hline
\end{tabular}

Sacral nerve stimulation for faecal incontinence and constipation in adults (Review)

Copyright @ 2015 The Cochrane Collaboration. Published by John Wiley \& Sons, Ltd. 


\begin{tabular}{|c|c|c|c|c|}
\hline Outcome or subgroup title & $\begin{array}{l}\text { No. of } \\
\text { studies }\end{array}$ & $\begin{array}{c}\text { No. of } \\
\text { participants }\end{array}$ & Statistical method & Effect size \\
\hline $\begin{array}{l}1 \text { Episodes of faecal incontinence } \\
\text { per week }\end{array}$ & 1 & & Mean Difference (IV, Fixed, 95\% CI) & Totals not selected \\
\hline 1.1 At 3 months & 1 & & Mean Difference (IV, Fixed, 95\% CI) & $0.0[0.0,0.0]$ \\
\hline 1.2 At 6 months & 1 & & Mean Difference (IV, Fixed, 95\% CI) & $0.0[0.0,0.0]$ \\
\hline $\begin{array}{l}2 \text { Cleveland Clinic Incontinence } \\
\text { Score }\end{array}$ & 1 & & Mean Difference (IV, Fixed, 95\% CI) & Totals not selected \\
\hline 2.1 At 3 months & 1 & & Mean Difference (IV, Fixed, 95\% CI) & $0.0[0.0,0.0]$ \\
\hline 2.2 At 6 months & 1 & & Mean Difference (IV, Fixed, 95\% CI) & $0.0[0.0,0.0]$ \\
\hline 3 FIQL Lifestyle & 1 & & Mean Difference (IV, Fixed, 95\% CI) & Totals not selected \\
\hline 3.1 At 3 months & 1 & & Mean Difference (IV, Fixed, 95\% CI) & $0.0[0.0,0.0]$ \\
\hline 3.2 At 6 months & 1 & & Mean Difference (IV, Fixed, 95\% CI) & $0.0[0.0,0.0]$ \\
\hline 4 FIQL Coping & 1 & & Mean Difference (IV, Fixed, 95\% CI) & Totals not selected \\
\hline 4.1 At 3 months & 1 & & Mean Difference (IV, Fixed, 95\% CI) & $0.0[0.0,0.0]$ \\
\hline 4.2 At 6 months & 1 & & Mean Difference (IV, Fixed, 95\% CI) & $0.0[0.0,0.0]$ \\
\hline 5 FIQL Depression & 1 & & Mean Difference (IV, Fixed, 95\% CI) & Totals not selected \\
\hline 5.1 At 3 months & 1 & & Mean Difference (IV, Fixed, 95\% CI) & $0.0[0.0,0.0]$ \\
\hline 5.2 At 6 months & 1 & & Mean Difference (IV, Fixed, 95\% CI) & $0.0[0.0,0.0]$ \\
\hline 6 FIQL Embarrassment & 1 & & Mean Difference (IV, Fixed, 95\% CI) & Totals not selected \\
\hline 6.1 At 3 months & 1 & & Mean Difference (IV, Fixed, 95\% CI) & $0.0[0.0,0.0]$ \\
\hline 6.2 At 6 months & 1 & & Mean Difference (IV, Fixed, 95\% CI) & $0.0[0.0,0.0]$ \\
\hline 7 EQ-5D & 1 & & Mean Difference (IV, Fixed, 95\% CI) & Totals not selected \\
\hline 7.1 At 3 months & 1 & & Mean Difference (IV, Fixed, 95\% CI) & $0.0[0.0,0.0]$ \\
\hline 7.2 At 6 months & 1 & & Mean Difference (IV, Fixed, 95\% CI) & $0.0[0.0,0.0]$ \\
\hline
\end{tabular}

Comparison 3. Faecal incontinence: crossover trials

$\begin{array}{lllll}\text { Outcome or subgroup title } & \begin{array}{c}\text { No. of } \\ \text { studies }\end{array} & \begin{array}{c}\text { No. of } \\ \text { participants }\end{array} & \text { Statistical method } & \text { Effect size }\end{array}$

\begin{tabular}{|c|c|c|}
\hline $\begin{array}{l}1 \text { Participants cured and improved } \\
\text { on treatment }\end{array}$ & Other data & No numeric data \\
\hline $\begin{array}{l}2 \text { Episodes of faecal incontinence } \\
\text { per week }\end{array}$ & Other data & No numeric data \\
\hline $\begin{array}{l}3 \text { Ability to defer defaecation } \\
\text { (minutes) }\end{array}$ & Other data & No numeric data \\
\hline 4 Episodes of urgency per week & Other data & No numeric data \\
\hline 5 Days with pads per week & Other data & No numeric data \\
\hline $\begin{array}{l}6 \text { Cleveland Clinic Incontinence } \\
\text { Score }\end{array}$ & Other data & No numeric data \\
\hline 7 Quality of life - SF36 & Other data & No numeric data \\
\hline 8 Quality of life - SF12 & Other data & No numeric data \\
\hline 9 Quality of life - modified ASCRS & Other data & No numeric data \\
\hline 10 Quality of life - ASCRS FIQL & Other data & No numeric data \\
\hline 11 Anorectal manometry & Other data & No numeric data \\
\hline
\end{tabular}


11.1 Maximal resting pressure (cm H20)

11.2 Maximal squeeze pressure (cm H20)

11.3 Squeeze pressure duration (seconds)

11.4 Rectal volume sensation - threshold (ml)

11.5 Rectal volume sensation - urge (ml)

11.6 Rectal volume sensation

- maximal tolerated (ml)

11.7 Rectal volume sensation constant sensation volume $(\mathrm{ml})$

12 Bowel movements per week

13 Soiling/week

14 Days with staining per week

15 Days with incontinence per week

16 Passive leakage/week
Other data

Other data

Other data

Other data

Other data

Other data

Other data

Other data

Other data

Other data

Other data

Other data
No numeric data

No numeric data

No numeric data

No numeric data

No numeric data

No numeric data

No numeric data

No numeric data

No numeric data

No numeric data

No numeric data

No numeric data

\section{Comparison 4. Constipation}

\section{Outcome or subgroup title}

$\begin{array}{cc}\text { No. of } & \text { No. of } \\ \text { studies } & \text { participants }\end{array}$

1 Bowel movements per week

2 Time with abdominal pain and bloating (\%)

3 Wexner Constipation Score

4 Symptom Analogue Score

5 Anorectal manometry

5.1 Maximal resting pressure

( $\mathrm{cm} \mathrm{H}_{2}$ 0)

5.2 Maximal squeeze pressure

( $\mathrm{cm} \mathrm{H}_{2}$ 0)

5.3 Rectal volume sensation threshold ( $\mathrm{ml}$ air)

5.4 Rectal volume sensation urge ( $\mathrm{ml}$ air)

5.5 Rectal volume sensation maximal tolerated ( $\mathrm{ml}$ air)

6 Stool frequency (per week)

7 Pain score (weekly average)

8 Bloating score (weekly average)

9 Quality of life - SF36

10 Adverse events
Statistical method

Effect size

Other data

No numeric data

Other data

No numeric data

Other data

Other data

Other data

Other data

No numeric data

No numeric data

No numeric data

No numeric data

Other data

No numeric data

Other data

No numeric data

Other data

No numeric data

Other data

No numeric data

Other data

Other data

Other data

Other data

Other data
No numeric data

No numeric data

No numeric data

No numeric data

No numeric data 
Analysis I.I. Comparison I Faecal incontinence: parallel group data SNS vs medical therapy, Outcome I Episodes of faecal incontinence per week.

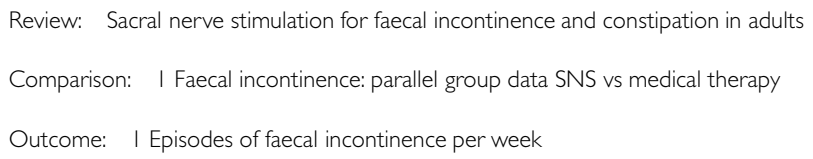

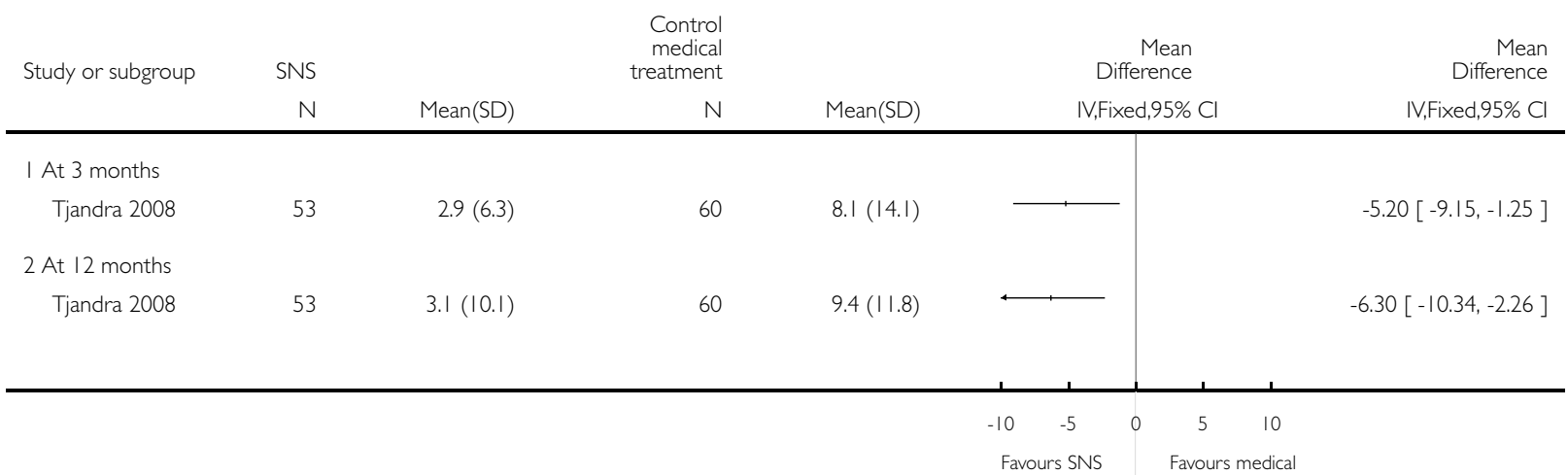

Analysis I.2. Comparison I Faecal incontinence: parallel group data SNS vs medical therapy, Outcome 2 Days using pads per week.

Review: Sacral nerve stimulation for faecal incontinence and constipation in adults

Comparison: I Faecal incontinence: parallel group data SNS vs medical therapy

Outcome: 2 Days using pads per week

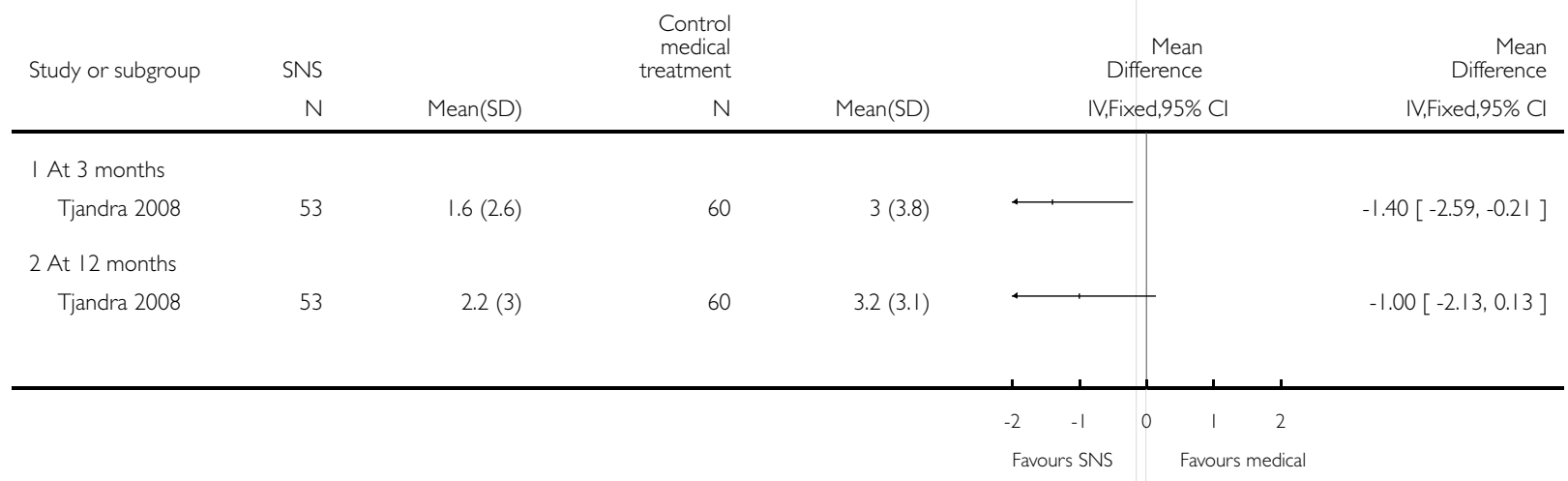


Analysis I.3. Comparison I Faecal incontinence: parallel group data SNS vs medical therapy, Outcome 3 Days with incontinence per week.

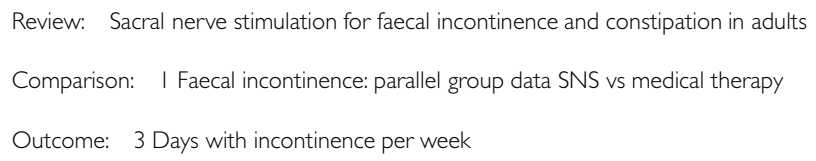

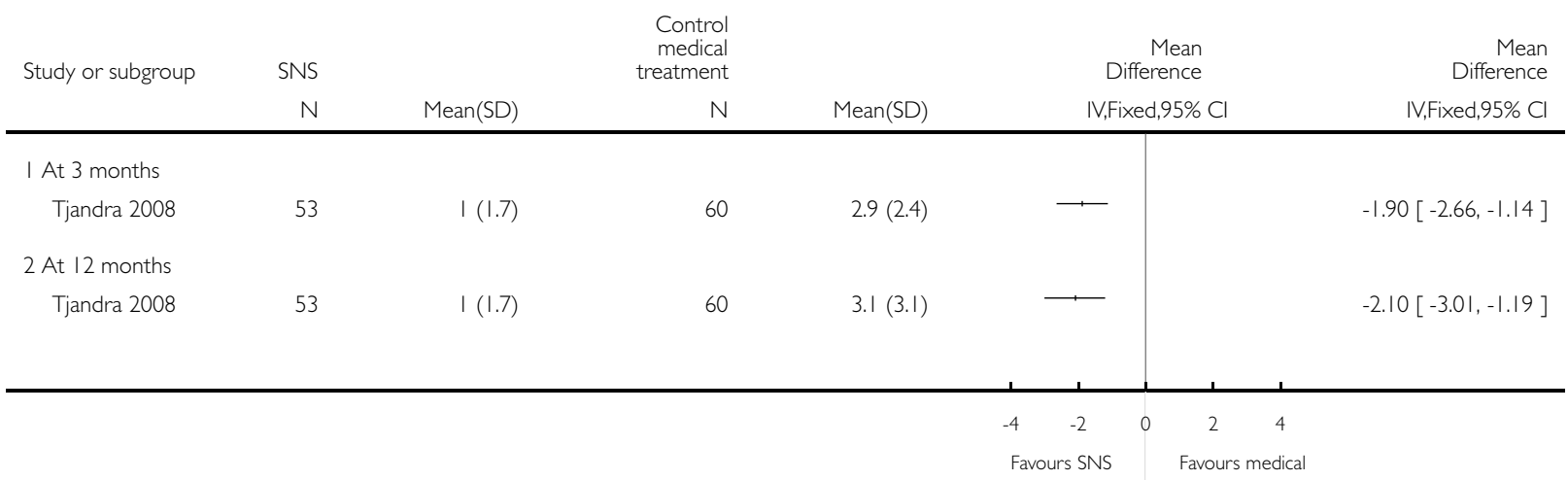

Analysis I.4. Comparison I Faecal incontinence: parallel group data SNS vs medical therapy, Outcome 4 Days with faecal staining per week.

Review: Sacral nerve stimulation for faecal incontinence and constipation in adults

Comparison: I Faecal incontinence: parallel group data SNS vs medical therapy

Outcome: 4 Days with faecal staining per week

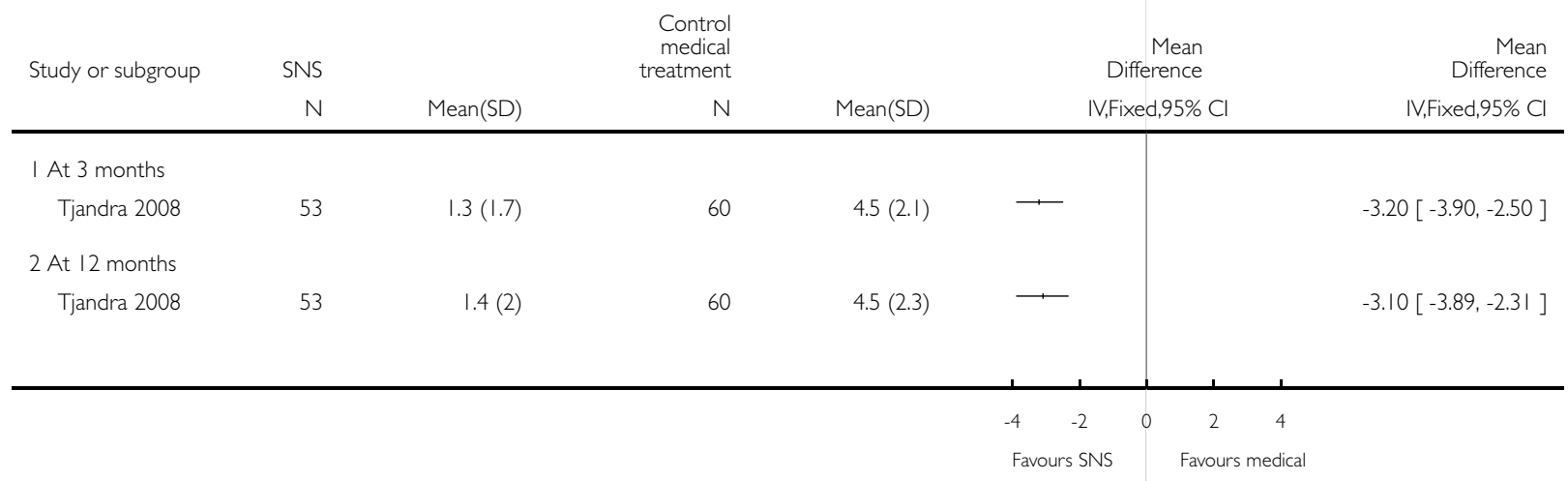


Analysis I.5. Comparison I Faecal incontinence: parallel group data SNS vs medical therapy, Outcome 5 Cleveland Clinic Incontinence Score.

Review: Sacral nerve stimulation for faecal incontinence and constipation in adults

Comparison: I Faecal incontinence: parallel group data SNS vs medical therapy

Outcome: 5 Cleveland Clinic Incontinence Score

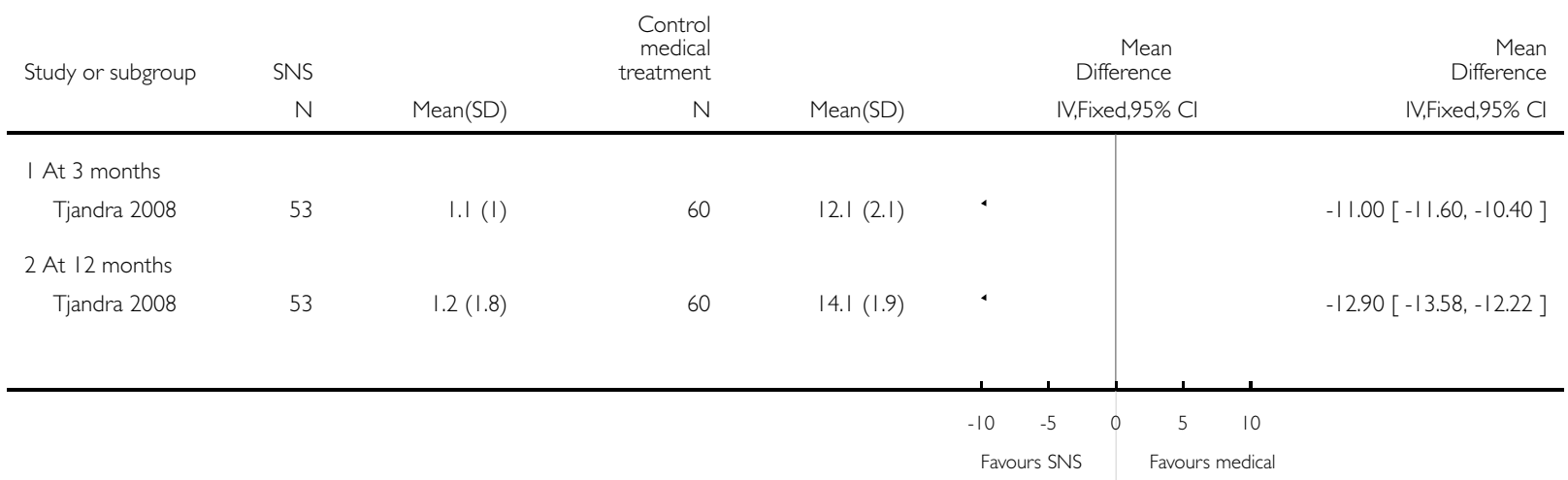

Analysis I.6. Comparison I Faecal incontinence: parallel group data SNS vs medical therapy, Outcome 6 SFI2 Physical.

Review: Sacral nerve stimulation for faecal incontinence and constipation in adults

Comparison: I Faecal incontinence: parallel group data SNS vs medical therapy

Outcome: 6 SFI2 Physical

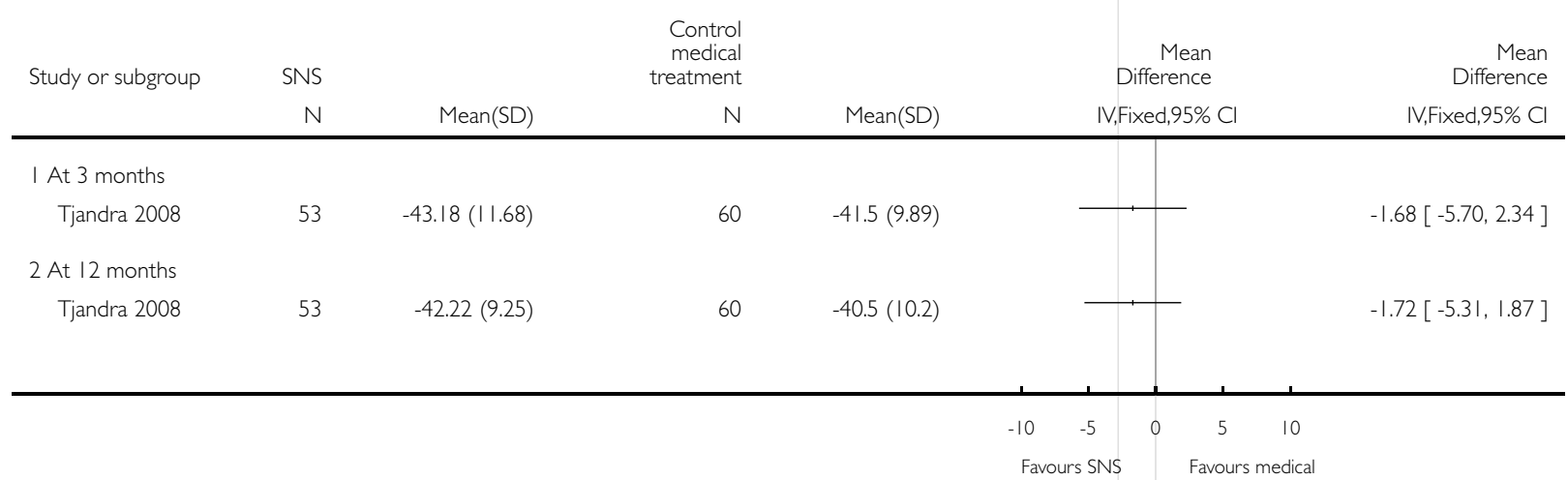


Analysis I.7. Comparison I Faecal incontinence: parallel group data SNS vs medical therapy, Outcome 7 SFI 2 Mental.

Review: Sacral nerve stimulation for faecal incontinence and constipation in adults

Comparison: I Faecal incontinence: parallel group data SNS vs medical therapy

Outcome: 7 SFI2 Mental

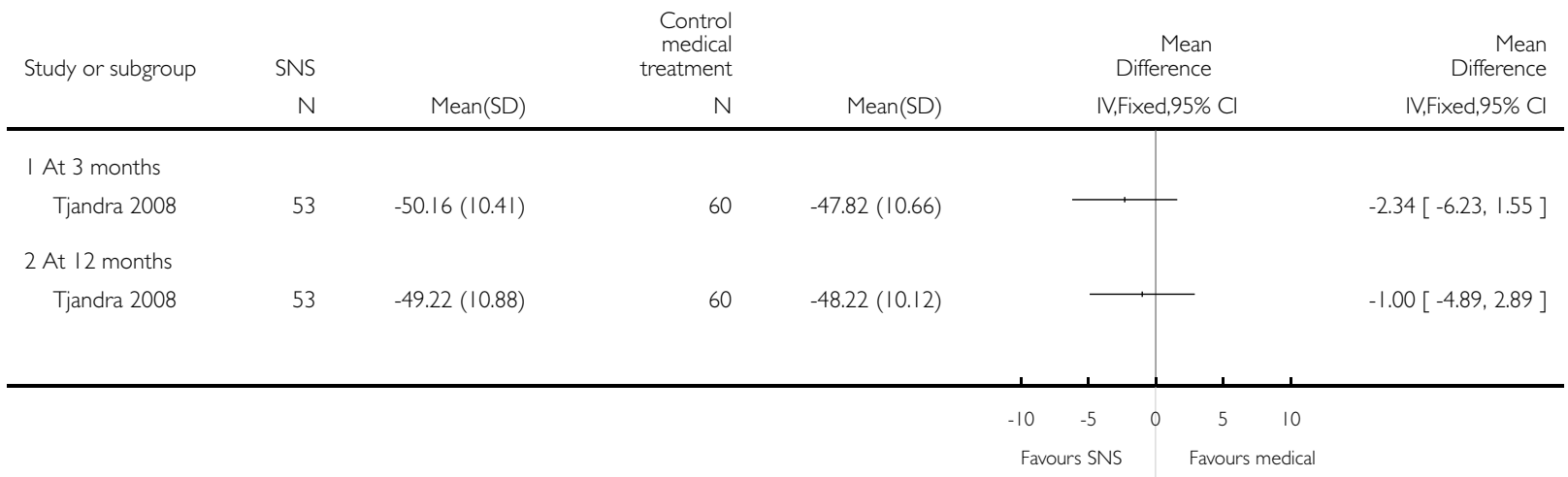

Analysis I.8. Comparison I Faecal incontinence: parallel group data SNS vs medical therapy, Outcome 8 FIQL Lifestyle.

Review: Sacral nerve stimulation for faecal incontinence and constipation in adults

Comparison: I Faecal incontinence: parallel group data SNS vs medical therapy

Outcome: 8 FIQL Lifestyle

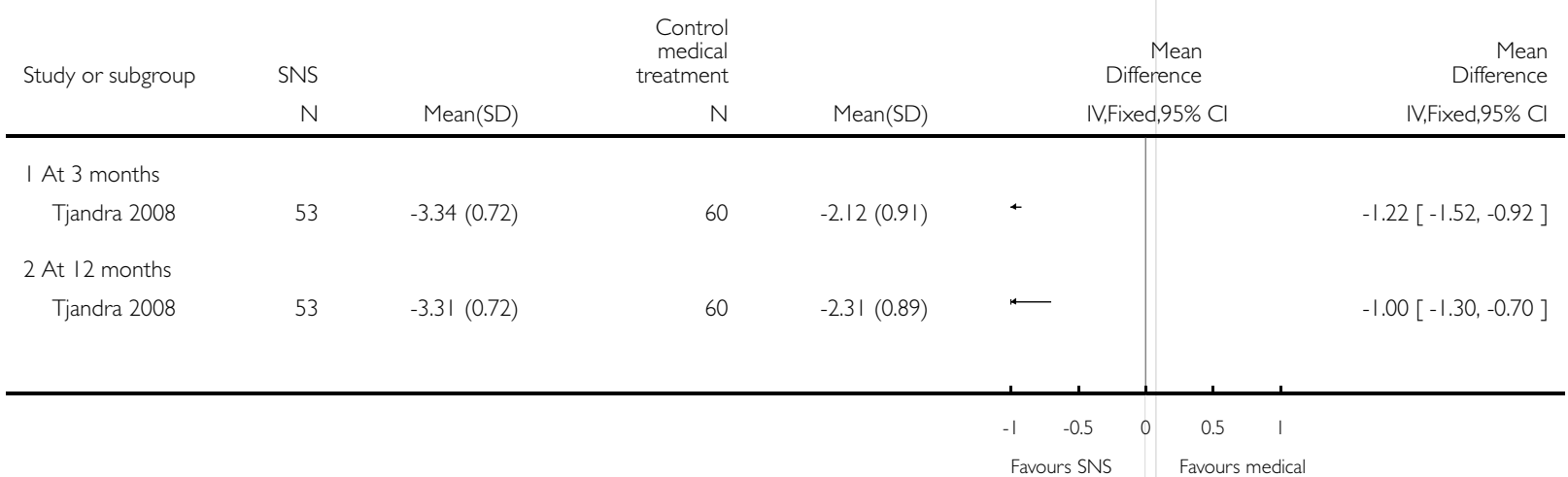


Analysis I.9. Comparison I Faecal incontinence: parallel group data SNS vs medical therapy, Outcome 9 FIQL Coping/behaviour.

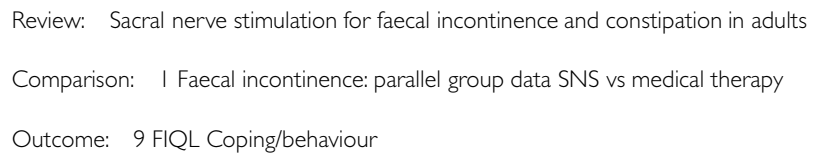

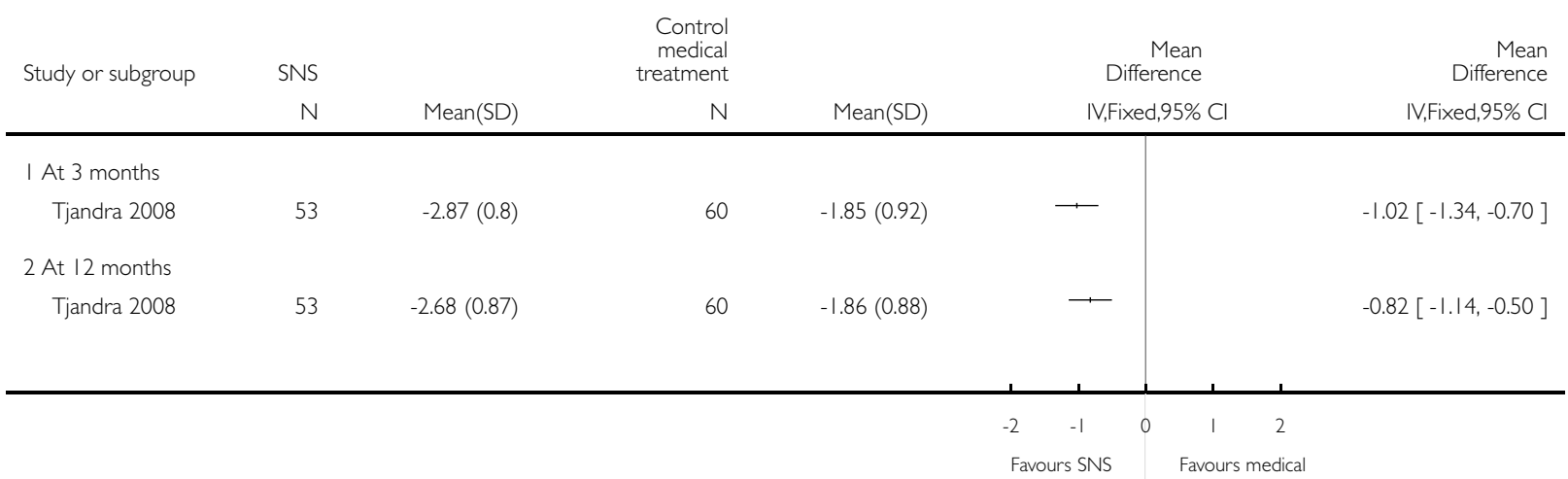

Analysis I.I0. Comparison I Faecal incontinence: parallel group data SNS vs medical therapy, Outcome I0 FIQL Depression/self perception.

Review: Sacral nerve stimulation for faecal incontinence and constipation in adults

Comparison: I Faecal incontinence: parallel group data SNS vs medical therapy

Outcome: $10 \mathrm{FIQL} \mathrm{Depression/self} \mathrm{perception}$

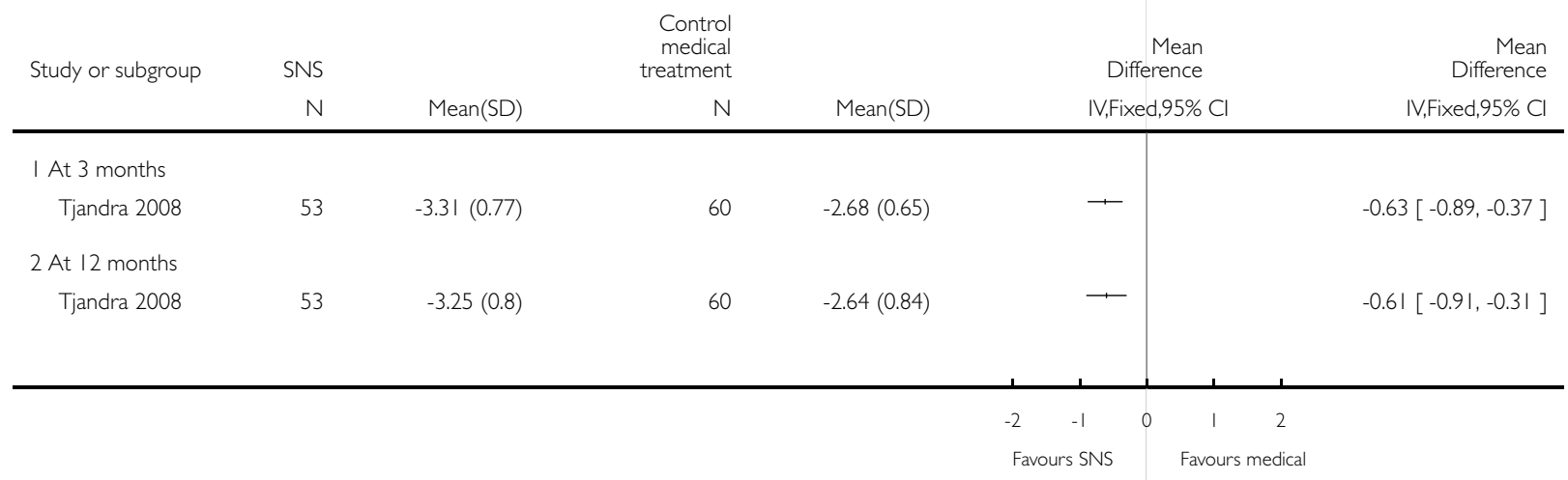




\section{Analysis I.I I. Comparison I Faecal incontinence: parallel group data SNS vs medical therapy, Outcome I I} FIQL Embarrassment.

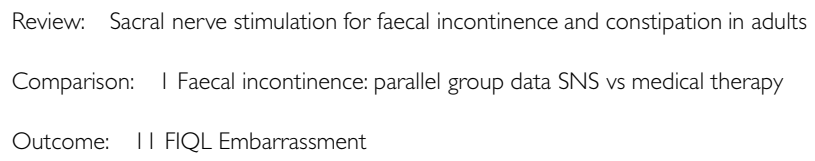

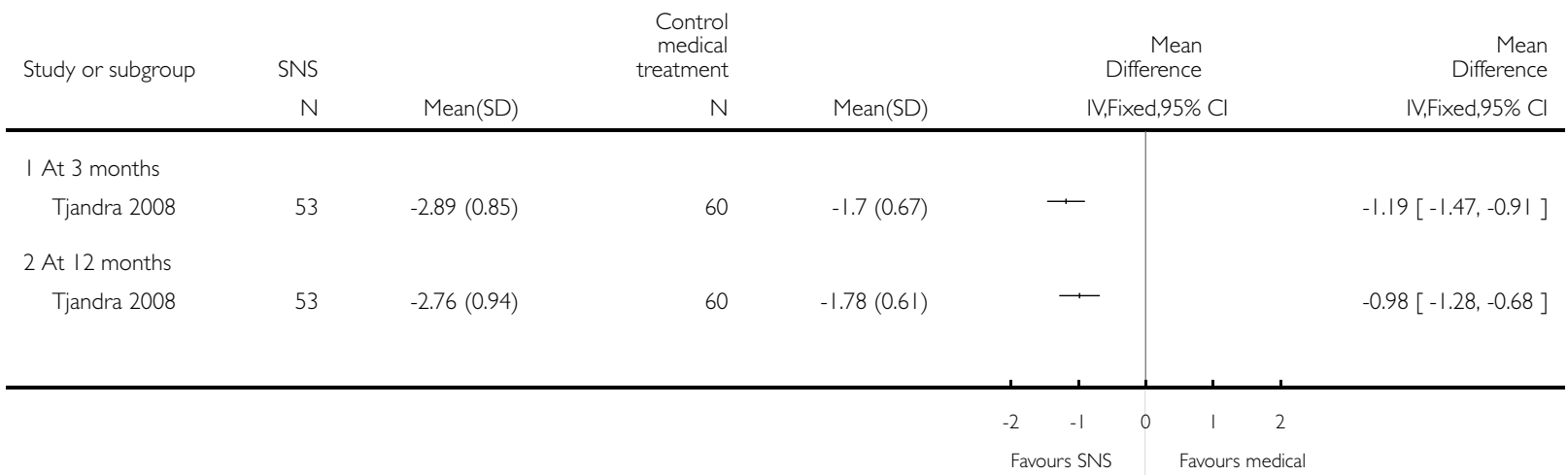

Analysis 2.I. Comparison 2 Faecal Incontinence: parallel group data SNS vs PTNS, Outcome I Episodes of faecal incontinence per week.

Review: Sacral nerve stimulation for faecal incontinence and constipation in adults

Comparison: 2 Faecal Incontinence: parallel group data SNS vs PTNS

Outcome: I Episodes of faecal incontinence per week

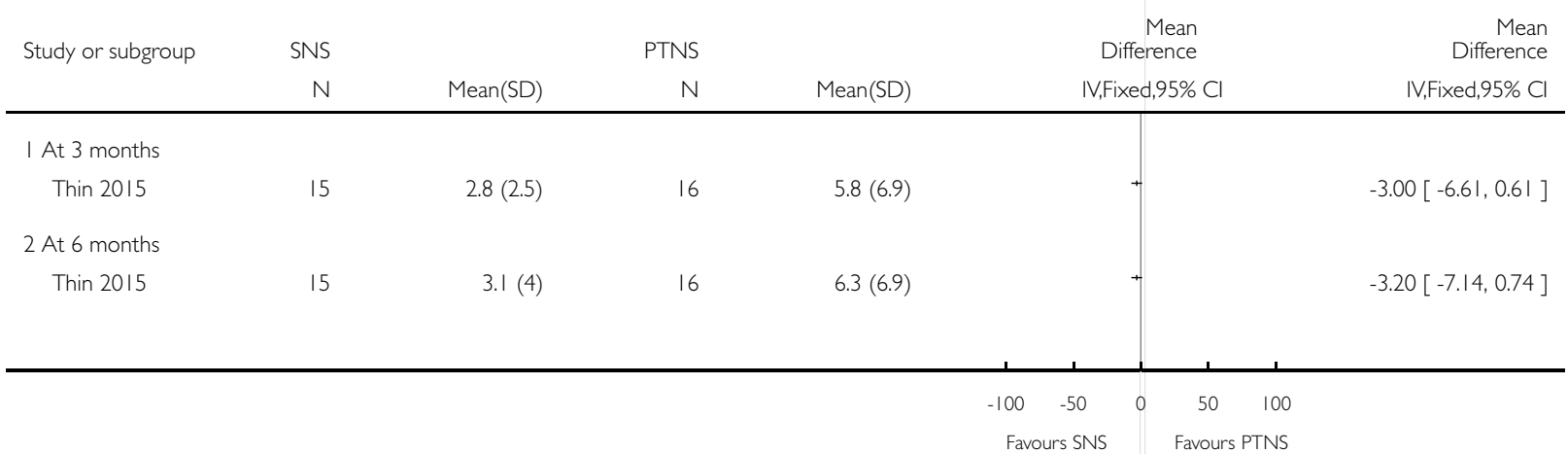


Analysis 2.2. Comparison 2 Faecal Incontinence: parallel group data SNS vs PTNS, Outcome 2 Cleveland Clinic Incontinence Score.

Review: Sacral nerve stimulation for faecal incontinence and constipation in adults

Comparison: 2 Faecal Incontinence: parallel group data SNS vs PTNS

Outcome: 2 Cleveland Clinic Incontinence Score

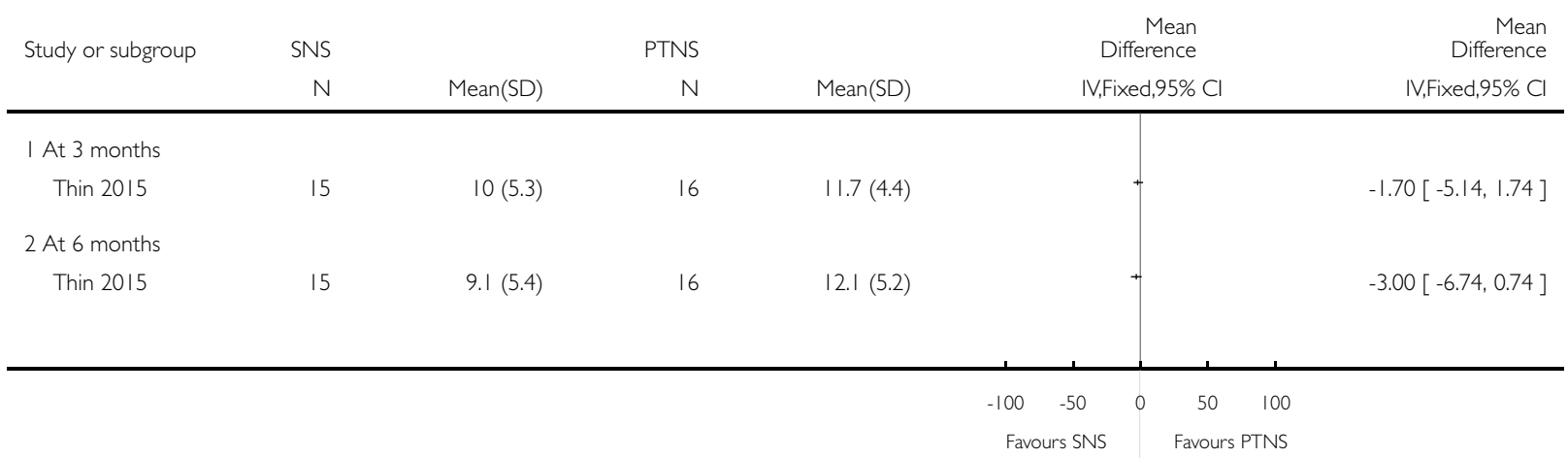

Analysis 2.3. Comparison 2 Faecal Incontinence: parallel group data SNS vs PTNS, Outcome 3 FIQL Lifestyle.

Review: Sacral nerve stimulation for faecal incontinence and constipation in adults

Comparison: 2 Faecal Incontinence: parallel group data SNS vs PTNS

Outcome: 3 FIQL Lifestyle

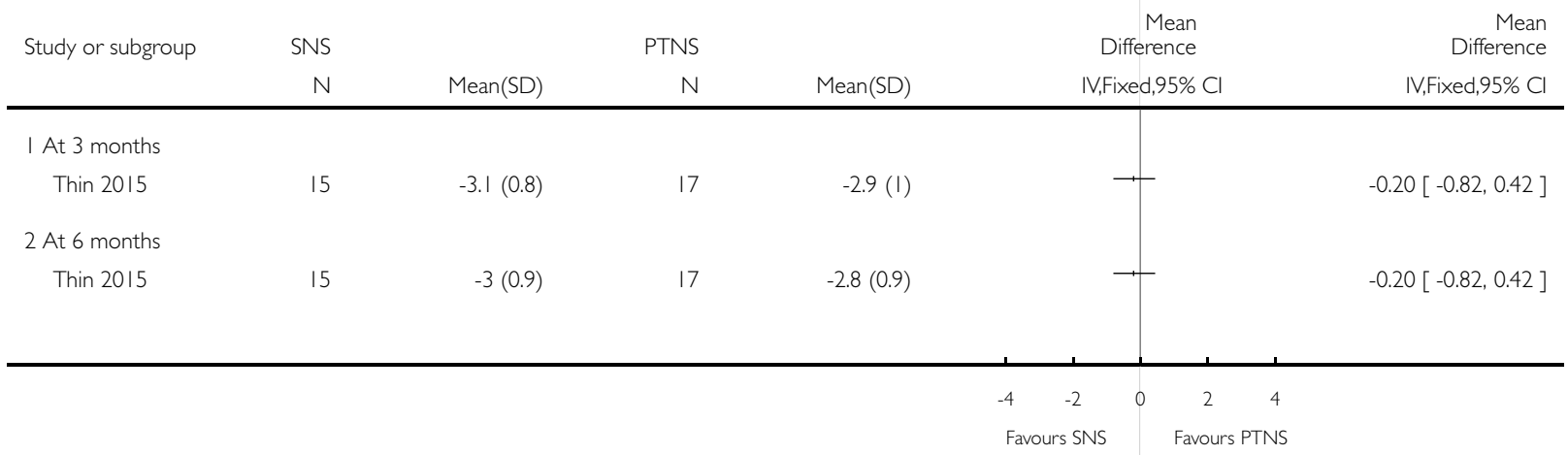


Analysis 2.4. Comparison 2 Faecal Incontinence: parallel group data SNS vs PTNS, Outcome 4 FIQL Coping.

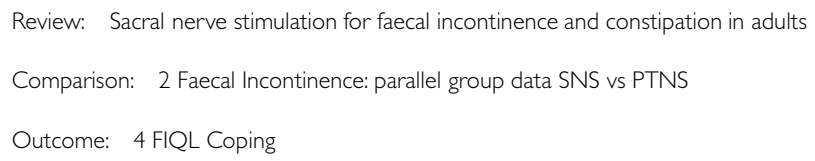

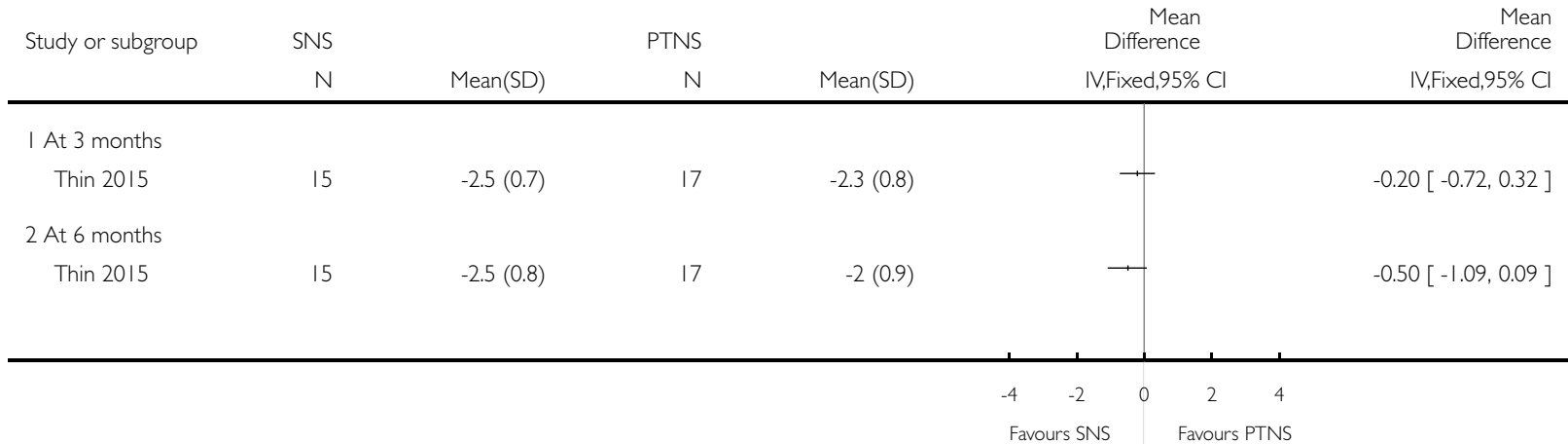

Analysis 2.5. Comparison 2 Faecal Incontinence: parallel group data SNS vs PTNS, Outcome 5 FIQL Depression.

Review: Sacral nerve stimulation for faecal incontinence and constipation in adults

Comparison: 2 Faecal Incontinence: parallel group data SNS vs PTNS

Outcome: 5 FIQL Depression

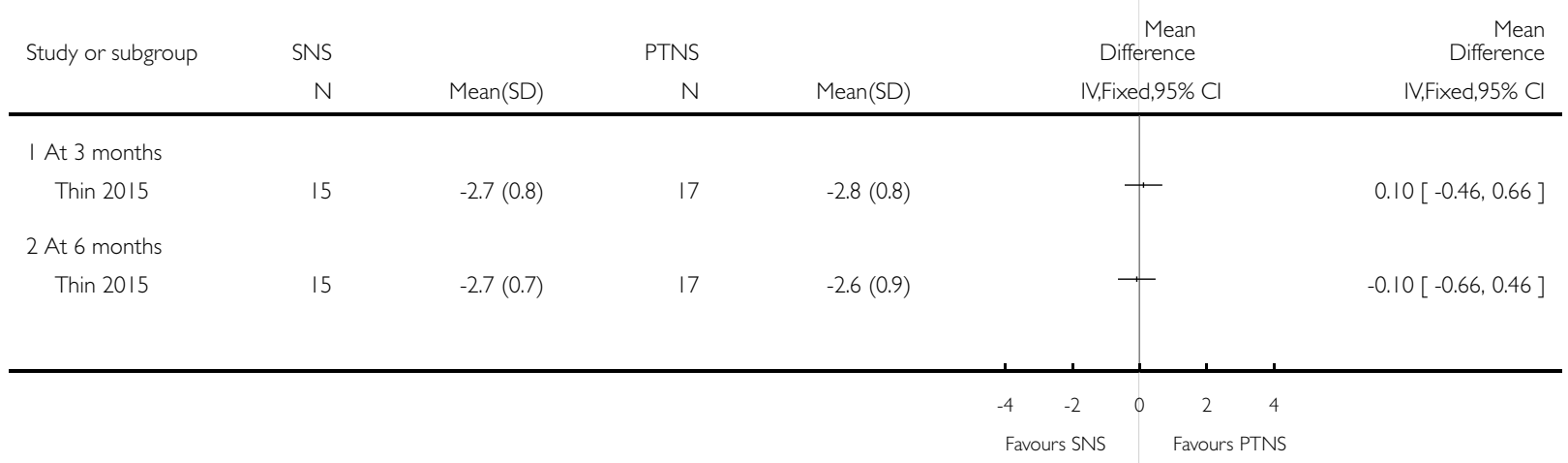


Analysis 2.6. Comparison 2 Faecal Incontinence: parallel group data SNS vs PTNS, Outcome 6 FIQL Embarrassment.

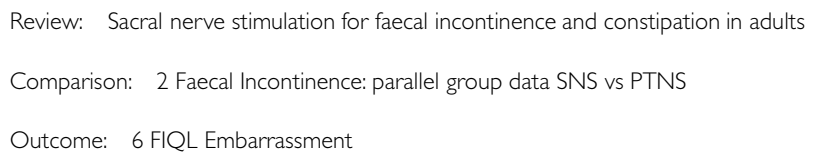

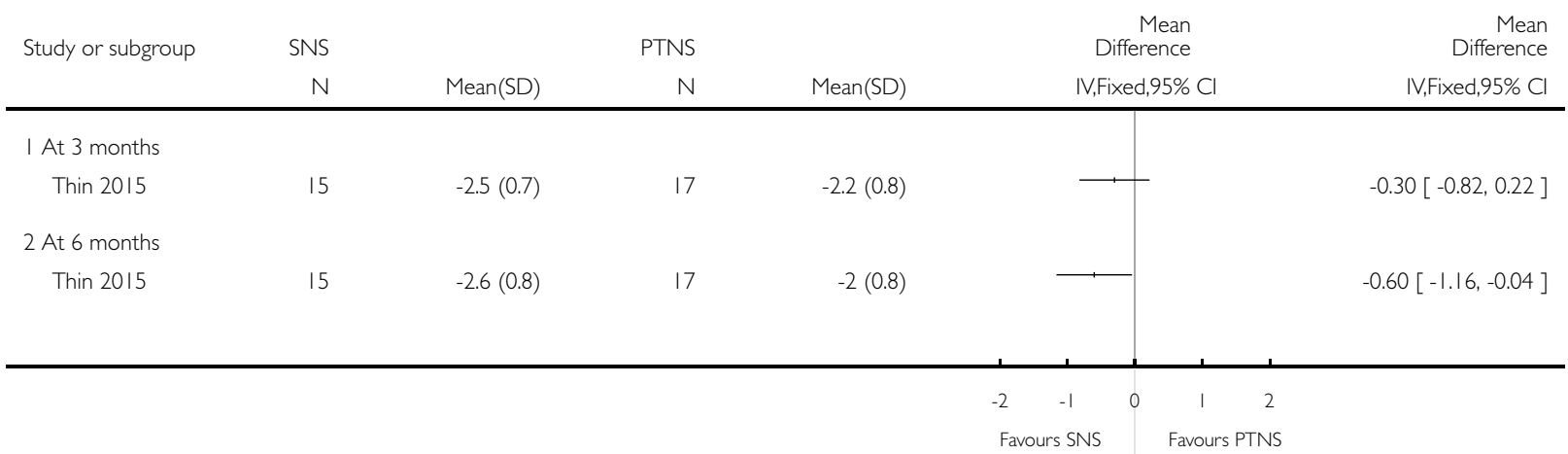

Analysis 2.7. Comparison 2 Faecal Incontinence: parallel group data SNS vs PTNS, Outcome 7 EQ-5D.

Review: Sacral nerve stimulation for faecal incontinence and constipation in adults

Comparison: 2 Faecal Incontinence: parallel group data SNS vs PTNS

Outcome: $7 \mathrm{EQ}-5 \mathrm{D}$

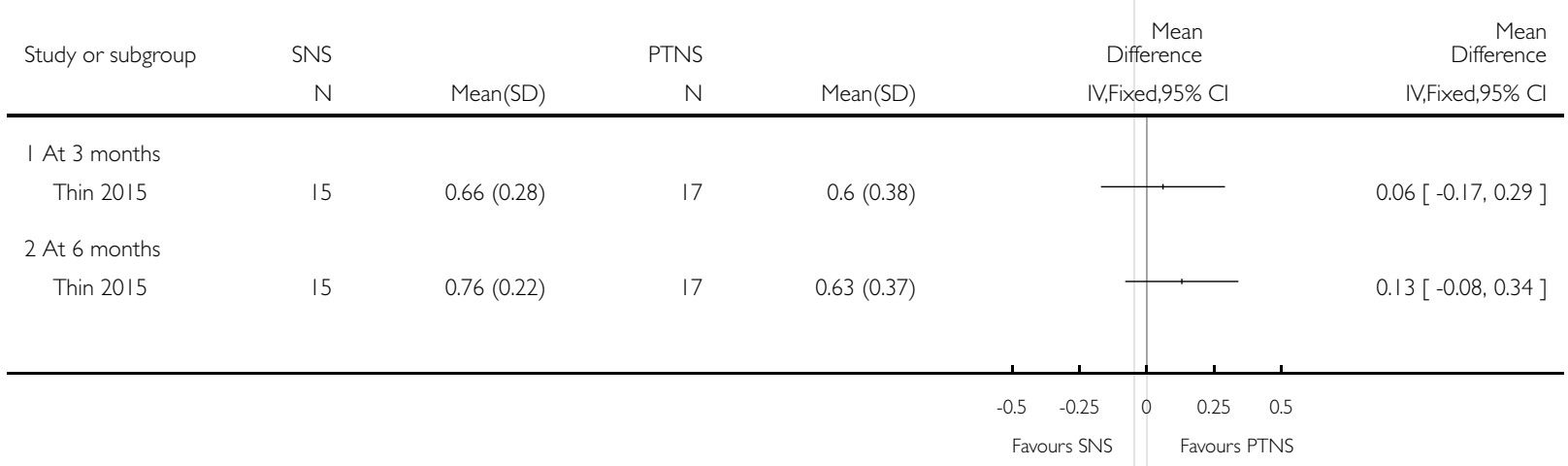


Analysis 3.I. Comparison 3 Faecal incontinence: crossover trials, Outcome I Participants cured and improved on treatment.

Participants cured and improved on treatment

\begin{tabular}{lllll}
\hline Study & Cured & $\%$ & Improved & $\%$ \\
\hline Leroi 2005\# & $5 / 19$ & 26 & $17 / 19$ & 89 \\
\hline Thin 2015 & $3 / 15$ & 20 & $10 / 15$ & 67 \\
\hline Tjandra 2008 & $22 / 53$ & 41.5 & $53 / 53$ & 100 \\
\hline Vaizey 2000\# & $1 / 2$ & 50 & $2 / 2$ & 100 \\
\hline
\end{tabular}

Analysis 3.2. Comparison 3 Faecal incontinence: crossover trials, Outcome 2 Episodes of faecal incontinence per week.

Episodes of faecal incontinence per week

\begin{tabular}{|c|c|c|c|c|c|c|c|c|c|c|}
\hline Study & Group & Measure & Patients & Baseline & $\begin{array}{l}\text { Three } \\
\text { months }\end{array}$ & $\begin{array}{l}\text { 'Off' pe- } \\
\text { riod }\end{array}$ & $\begin{array}{l}\text { 'On' pe- } \\
\text { riod }\end{array}$ & $\begin{array}{l}\text { Change } \\
(\%)\end{array}$ & $\begin{array}{l}\text { Follow- } \\
\text { up }\end{array}$ & Notes \\
\hline $\begin{array}{l}\text { Kahlke } \\
2015 \#\end{array}$ & & $\begin{array}{l}\text { Mean } \\
(\mathrm{SD})\end{array}$ & 14 & 18 (19.6) & & $8.4(8.7)$ & $1(1.7)$ & $\begin{array}{l}-7.4 \quad(\quad- \\
88 \%)\end{array}$ & $0.3(0.5)$ & $p<0.05$ \\
\hline \multicolumn{11}{|l|}{$\begin{array}{l}\text { Kahlke } \\
2015 \#\end{array}$} \\
\hline $\begin{array}{l}\text { Leroi } \\
2005 \#\end{array}$ & $\begin{array}{l}\text { Group } \\
\text { of } 19 \text { who } \\
\text { chose 'on' } \\
\text { following } \\
\text { the } \\
\text { crossover } \\
\text { period }\end{array}$ & $\begin{array}{l}\text { Median } \\
\text { (range) }\end{array}$ & $\begin{array}{l}\text { Baseline: } \\
16 \\
3 \\
\text { months: } \\
16 \\
\text { 'Off' pe- } \\
\text { riod: } 19 \\
\text { 'On' pe- } \\
\text { riod: } 19 \\
\text { Follow- } \\
\text { up: } 18\end{array}$ & $\begin{array}{l}3.5 \text { (0 to } \\
16)\end{array}$ & $\begin{array}{l}0.3 \text { (0 to } \\
3)\end{array}$ & $\begin{array}{l}1.7 \text { (0 to } \\
9)\end{array}$ & $\begin{array}{l}0.7 \text { (0 to } \\
5)\end{array}$ & $-1(-59 \%)$ & $\begin{array}{l}0.5 \text { (0 to } \\
11)\end{array}$ & $\begin{array}{l}1 . \\
\mathrm{P}<0.05 \text { : } \\
\text { 'off' ver- } \\
\text { sus 'on' } \\
\text { period; } 3 \\
\text { months, } \\
\text { 'off' pe- } \\
\text { riod, 'on' } \\
\text { period, } \\
\text { follow- } \\
\text { up period } \\
\text { versus } \\
\text { baseline }\end{array}$ \\
\hline $\begin{array}{l}\text { Leroi } \\
2005 \#\end{array}$ & $\begin{array}{l}\text { Group } \\
\text { of } 5 \text { who } \\
\text { chose } \\
\text { 'off' fol- } \\
\text { lowing } \\
\text { the } \\
\text { crossover }\end{array}$ & $\begin{array}{l}\text { Median } \\
\text { (range) }\end{array}$ & $\begin{array}{l}\text { Baseline: } \\
5 \\
3 \\
\text { months: } \\
4 \\
\text { 'Off' pe- } \\
\text { riod: } 5\end{array}$ & $\begin{array}{l}7 \quad(0 \text { to } \\
11)\end{array}$ & $\begin{array}{l}1.9 \text { (1 to } \\
10)\end{array}$ & $\begin{array}{l}1.7 \text { (0 to } \\
11)\end{array}$ & $\begin{array}{l}3.7 \text { (0 to } \\
11)\end{array}$ & $2(118 \%)$ & $\begin{array}{l}3.5 \text { (0 to } \\
10)\end{array}$ & \\
\hline
\end{tabular}


Episodes of faecal incontinence per week (Continued)

\begin{tabular}{|c|c|c|c|c|c|c|c|c|c|c|}
\hline & period & & $\begin{array}{l}\text { 'On' pe- } \\
\text { riod: } 5 \\
\text { Follow- } \\
\text { up: } 5\end{array}$ & & & & & & & \\
\hline $\begin{array}{l}\text { Sørensen } \\
2010 \#\end{array}$ & & Mean & 7 & & & 0 & 0 & 0 & & \\
\hline \multicolumn{11}{|l|}{$\begin{array}{l}\text { Sørensen } \\
2010 \#\end{array}$} \\
\hline $\begin{array}{l}\text { Thin } \\
2015\end{array}$ & $\begin{array}{l}\text { PTNS } \\
\text { group }\end{array}$ & Mean \pm SD & 16 & $\begin{array}{l}10.6 \pm 11 \\
2\end{array}$ & $5.8 \pm 6.9$ & & & $\begin{array}{l}-4.3 \\
41 \%)\end{array}$ & $6.3 \pm 6.9$ & $\begin{array}{l}\text { Follow up } \\
\text { was at } 6 \\
\text { months. } \\
\% \text { change } \\
\text { is re- } \\
\text { ported as } \\
\text { the differ- } \\
\text { ence be- } \\
\text { tween } \\
\text { baseline } \\
\text { and at } 6 \\
\text { months }\end{array}$ \\
\hline $\begin{array}{l}\text { Thin } \\
2015\end{array}$ & $\begin{array}{l}\text { SNS } \\
\text { group }\end{array}$ & Mean \pm SD & 15 & $\begin{array}{l}12.1 \pm 13 \\
7\end{array}$ & $2.8 \pm 2.5$ & & & $-9(-74 \%)$ & $3.1 \pm 4.0$ & $\begin{array}{l}\text { Follow up } \\
\text { was at } 6 \\
\text { months. } \\
\% \text { change } \\
\text { is re- } \\
\text { ported as } \\
\text { the differ- } \\
\text { ence be- } \\
\text { tween } \\
\text { baseline } \\
\text { and at } 6 \\
\text { months }\end{array}$ \\
\hline $\begin{array}{l}\text { Tjandra } \\
2008\end{array}$ & $\begin{array}{l}\text { Control } \\
\text { group }\end{array}$ & Mean \pm SD & 60 & $9.2 \pm 13.4$ & $8.1 \pm 14.1$ & & & $0.2(2 \%)$ & $9.4 \pm 11.8$ & $\begin{array}{l}\mathrm{P}>0 . \\
05 \text { at } 3 \\
\text { months } \\
\text { and } 12 \\
\text { months } \\
\text { com- } \\
\text { pared } \\
\text { with } \\
\text { baseline. } \\
\text { Follow- } \\
\text { up was }\end{array}$ \\
\hline
\end{tabular}


Episodes of faecal incontinence per week (Continued)

\begin{tabular}{|c|c|c|c|c|c|c|c|c|c|c|}
\hline & & & & & & & & & & $\begin{array}{l}\text { at } 12 \\
\text { months. } \\
\% \text { change } \\
\text { is re- } \\
\text { ported } \\
\text { as the } \\
\text { difference } \\
\text { between } \\
\text { baseline } \\
\text { and at } 12 \\
\text { months }\end{array}$ \\
\hline $\begin{array}{l}\text { Tjandra } \\
2008\end{array}$ & $\begin{array}{l}\text { SNS } \\
\text { group }\end{array}$ & Mean \pm SD & 53 & $9.5 \pm 12.8$ & $2.9 \pm 6.3$ & & & $\begin{array}{l}-6.4 \\
67 \%)\end{array}$ & $3.1 \pm 10.1$ & $\begin{array}{l}\mathrm{P}<0 . \\
0001 \quad \text { at } \\
\text { all time } \\
\text { points } \\
\text { com- } \\
\text { pared } \\
\text { with } \\
\text { baseline. } \\
\text { Follow- } \\
\text { up was } \\
\text { at } 12 \\
\text { months. } \\
\% \text { change } \\
\text { is re- } \\
\text { ported } \\
\text { as the } \\
\text { difference } \\
\text { between } \\
\text { baseline } \\
\text { and at } 12 \\
\text { months }\end{array}$ \\
\hline $\begin{array}{l}\text { Vaizey } \\
2000 \#\end{array}$ & & $\begin{array}{l}\text { Mean } \\
\text { (range) }\end{array}$ & 2 & $\begin{array}{l}10 \text { (5 and } \\
15)\end{array}$ & & $\begin{array}{l}6(2 \text { and } \\
10)\end{array}$ & $\begin{array}{l}1 \text { (0 and } \\
1)\end{array}$ & $-5(-83 \%)$ & & \\
\hline $\begin{array}{l}\text { Vaizey } \\
2000 \#\end{array}$ & & & & & & & & & & \\
\hline
\end{tabular}

Analysis 3.3. Comparison 3 Faecal incontinence: crossover trials, Outcome 3 Ability to defer defaecation (minutes).

Ability to defer defaecation (minutes)

\begin{tabular}{|c|c|c|c|c|c|c|c|c|c|c|}
\hline Study & Group & Measure & Patients & Baseline & $\begin{array}{l}\text { Three } \\
\text { months }\end{array}$ & $\begin{array}{l}\text { 'Off' pe- } \\
\text { riod }\end{array}$ & $\begin{array}{l}\text { 'On' pe- } \\
\text { riod }\end{array}$ & $\begin{array}{l}\text { Change } \\
(\%)\end{array}$ & $\begin{array}{l}\text { Follow- } \\
\text { up }\end{array}$ & Notes \\
\hline
\end{tabular}


Ability to defer defaecation (minutes) (Continued)

\begin{tabular}{|c|c|c|c|c|c|c|c|c|c|c|}
\hline $\begin{array}{l}\text { Leroi } \\
\text { 2005\# }\end{array}$ & $\begin{array}{l}\text { Group } \\
\text { of } 19 \text { who } \\
\text { chose 'on' } \\
\text { following } \\
\text { the } \\
\text { crossover } \\
\text { period }\end{array}$ & $\begin{array}{l}\text { Median } \\
\text { (range) }\end{array}$ & $\begin{array}{l}\text { Baseline: } \\
13 \\
3 \\
\text { months: } \\
13 \\
\text { 'Off' pe- } \\
\text { riod: } 17 \\
\text { 'On' pe- } \\
\text { riod: } 14 \\
\text { Follow- } \\
\text { up: } 15\end{array}$ & 1 (1 to 2$)$ & $\begin{array}{l}1.8 \text { (1 to } \\
3)\end{array}$ & $\begin{array}{l}1.4 \text { (1 to } \\
3)\end{array}$ & $\begin{array}{l}1.8 \text { (1 to } \\
3)\end{array}$ & $\begin{array}{l}0.4 \\
(29 \%)\end{array}$ & $\begin{array}{l}1.9 \text { (1 to } \\
3)\end{array}$ & $\begin{array}{l}1 . \quad P \\
<0.05: 3 \\
\text { months, } \\
\text { 'off' pe- } \\
\text { riod, 'on' } \\
\text { period, } \\
\text { follow- } \\
\text { up versus } \\
\text { baseline }\end{array}$ \\
\hline $\begin{array}{l}\text { Leroi } \\
2005 \#\end{array}$ & $\begin{array}{l}\text { Group } \\
\text { of } 5 \text { who } \\
\text { chose } \\
\text { 'off' fol- } \\
\text { lowing } \\
\text { the } \\
\text { crossover } \\
\text { period }\end{array}$ & $\begin{array}{l}\text { Median } \\
\text { (range) }\end{array}$ & $\begin{array}{l}\text { Baseline: } \\
4 \\
3 \\
\text { months: } \\
4 \\
\text { 'Off' pe- } \\
\text { riod: } 5 \\
\text { 'On' pe- } \\
\text { riod: } 4 \\
\text { Follow- } \\
\text { up: } 4\end{array}$ & $1(1)$ & 1 (1 to 3$)$ & 1 (1 to 3$)$ & 1 (1 to 2$)$ & 0 & $\begin{array}{l}1.2 \text { (1 to } \\
1.8)\end{array}$ & \\
\hline
\end{tabular}

Analysis 3.4. Comparison 3 Faecal incontinence: crossover trials, Outcome 4 Episodes of urgency per week. Episodes of urgency per week

\begin{tabular}{|c|c|c|c|c|c|c|c|c|c|c|}
\hline Study & Group & Measure & Patients & Baseline & $\begin{array}{l}\text { Three } \\
\text { months }\end{array}$ & $\begin{array}{l}\text { 'Off' pe- } \\
\text { riod }\end{array}$ & $\begin{array}{l}\text { 'On' pe- } \\
\text { riod }\end{array}$ & $\begin{array}{l}\text { Change } \\
(\%)\end{array}$ & $\begin{array}{l}\text { Follow- } \\
\text { up }\end{array}$ & Notes \\
\hline $\begin{array}{l}\text { Leroi } \\
2005 \#\end{array}$ & $\begin{array}{l}\text { Group } \\
\text { of } 19 \text { who } \\
\text { chose 'on' } \\
\text { following } \\
\text { the } \\
\text { crossover } \\
\text { period }\end{array}$ & $\begin{array}{l}\text { Median } \\
\text { (range) }\end{array}$ & $\begin{array}{l}\text { Baseline: } \\
14 \\
3 \\
\text { months: } \\
14 \\
\text { 'Off' pe- } \\
\text { riod: } 18 \\
\text { 'On' pe- } \\
\text { riod: } 17 \\
\text { Follow- } \\
\text { up: } 17\end{array}$ & $\begin{array}{l}2.3 \text { (0 to } \\
26)\end{array}$ & $\begin{array}{l}1.4 \text { (0 to } \\
14)\end{array}$ & $\begin{array}{l}1.4 \text { (0 to } \\
19)\end{array}$ & $\begin{array}{l}1 \quad(0 \text { to } \\
16)\end{array}$ & $\begin{array}{l}-0.4 \\
29 \%)\end{array}$ & $\begin{array}{l}1 \quad(0 \text { to } \\
24)\end{array}$ & \\
\hline $\begin{array}{l}\text { Leroi } \\
2005 \#\end{array}$ & $\begin{array}{l}\text { Group } \\
\text { of } 5 \text { who } \\
\text { chose } \\
\text { 'off' fol- } \\
\text { lowing }\end{array}$ & $\begin{array}{l}\text { Median } \\
\text { (range) }\end{array}$ & $\begin{array}{l}\text { Baseline: } \\
4 \\
3 \\
\text { months: } \\
3\end{array}$ & $\begin{array}{l}10.4(0 \text { to } \\
17)\end{array}$ & $\begin{array}{l}0.4 \quad(0 \text { to } \\
9)\end{array}$ & $\begin{array}{l}4.5 \text { (3 to } \\
10)\end{array}$ & $\begin{array}{l}8.2 \text { (2 to } \\
19)\end{array}$ & $\begin{array}{l}3.7 \\
(82 \%)\end{array}$ & $\begin{array}{l}5.2 \text { (0 to } \\
20)\end{array}$ & \\
\hline
\end{tabular}


Episodes of urgency per week (Continued)

\begin{tabular}{|c|c|c|c|c|c|c|}
\hline & $\begin{array}{l}\text { the } \\
\text { crossover } \\
\text { period }\end{array}$ & & $\begin{array}{l}\text { 'Off' pe- } \\
\text { riod: } 4 \\
\text { 'On' pe- } \\
\text { riod: } 4 \\
\text { Follow- } \\
\text { up: } 4\end{array}$ & & & \\
\hline $\begin{array}{l}\text { Sørensen } \\
2010 \#\end{array}$ & & $\begin{array}{l}\text { Mean } \\
(95 \% \text { CI } \\
\text { for mean) }\end{array}$ & 7 & $\begin{array}{l}4.14 \quad(-0 . \\
16-8.44)\end{array}$ & $\begin{array}{l}2.43 \quad(-0 . \\
23-5.1)\end{array}$ & $\begin{array}{l}-1.71 \\
70 \%)\end{array}$ \\
\hline $\begin{array}{l}\text { Sørensen } \\
2010 \#\end{array}$ & & & & & & \\
\hline
\end{tabular}

Analysis 3.5. Comparison 3 Faecal incontinence: crossover trials, Outcome 5 Days with pads per week.

Days with pads per week

\begin{tabular}{|c|c|c|c|c|c|c|c|c|}
\hline Study & Group & Measure & Patients & Baseline & $\begin{array}{l}\text { Three } \\
\text { months }\end{array}$ & 12 months & Change (\%) & Notes \\
\hline $\begin{array}{l}\text { Tjandra } \\
2008\end{array}$ & $\begin{array}{l}\text { Control } \\
\text { group }\end{array}$ & Mean \pm SD & 60 & $3.7 \pm 3.4$ & $3 \pm 3.8$ & $3.2 \pm 3.1$ & $-0.5(-14 \%)$ & $\begin{array}{l}\mathrm{P}>0.05 \text { at } 3 \\
\text { months and } 12 \\
\text { months compared } \\
\text { with baseline. } \% \\
\text { change is reported } \\
\text { as the difference } \\
\text { between baseline } \\
\text { and at } 12 \text { months }\end{array}$ \\
\hline $\begin{array}{l}\text { Tjandra } \\
2008\end{array}$ & SNS group & Mean \pm SD & 53 & $3.8 \pm 3$ & $1.6 \pm 2.6$ & $2.2 \pm 3$ & $-1.6(-42 \%)$ & $\begin{array}{l}\mathrm{P}<0.0001 \text { at all } \\
\text { time points com- } \\
\text { pared with base- } \\
\text { line. } \% \text { change is } \\
\text { reported as the dif- } \\
\text { ference between } \\
\text { baseline and at } 12 \\
\text { months }\end{array}$ \\
\hline
\end{tabular}

Analysis 3.6. Comparison 3 Faecal incontinence: crossover trials, Outcome 6 Cleveland Clinic Incontinence Score.

Cleveland Clinic Incontinence Score

\begin{tabular}{l|lll|l|l|l|l|l|l|l}
\hline Study & Group & Measure & Patients & Baseline & $\begin{array}{l}\text { Three } \\
\text { months }\end{array}$ & $\begin{array}{l}\text { 'Off pe- 'On' pe- } \begin{array}{l}\text { Change } \\
\text { riod }\end{array} \\
\text { riod }\end{array}$ & $\begin{array}{l}\text { Follow- } \\
\text { up }\end{array}$ & Notes \\
\hline $\begin{array}{l}\text { Kahlke } \\
2015 \#\end{array}$ & Mean & 14 & $16(4.6)$ & & $14.6(4.6)$ & $8.7(3.6)$ & $\begin{array}{l}-5.9 \\
40 \%)\end{array}$ & $(-6.4(3.3)$ & $\mathrm{p}<0.05$ \\
\hline
\end{tabular}

Sacral nerve stimulation for faecal incontinence and constipation in adults (Review)

Copyright $\Subset 2015$ The Cochrane Collaboration. Published by John Wiley \& Sons, Ltd. 
Cleveland Clinic Incontinence Score (Continued)

\begin{tabular}{|c|c|c|c|c|c|c|c|c|c|c|}
\hline $\begin{array}{l}\text { Kahlke } \\
\text { 2015\# }\end{array}$ & & & & & & & & & & \\
\hline $\begin{array}{l}\text { Kahlke } \\
\text { 2015\# }\end{array}$ & & & & & & & & & & \\
\hline $\begin{array}{l}\text { Leroi } \\
\text { 2005\# }\end{array}$ & $\begin{array}{l}\text { Whole } \\
\text { group }\end{array}$ & $\begin{array}{l}\text { Median } \\
\text { (range) }\end{array}$ & $\begin{array}{l}\text { Baseline: } \\
23 \\
3 \\
\text { months: } \\
16 \\
\text { 'Off' pe- } \\
\text { riod: } 15 \\
\text { 'On' pe- } \\
\text { riod: } 17\end{array}$ & $\begin{array}{l}16 \text { (8 to } \\
20)\end{array}$ & $\begin{array}{l}9 \quad(0 \text { to } \\
19)\end{array}$ & $\begin{array}{l}10.5 \text { (4 to } \\
17)\end{array}$ & $\begin{array}{l}8.5 \text { (3 to } \\
18)\end{array}$ & $-2(-19 \%)$ & $\begin{array}{l}\text { Not } \\
\text { reported } \\
\text { for whole } \\
\text { group }\end{array}$ & $\begin{array}{l}\text { 1. Cleve- } \\
\text { land } \\
\text { Clinic } \\
\text { scores are } \\
\text { reported } \\
\text { for whole } \\
\text { group. } \\
2 . \\
\text { The score } \\
\text { ranges } \\
\text { from } \\
0 \text { (normal } \\
\text { conti- } \\
\text { nence) to } \\
20 \text { (max- } \\
\text { imum in- } \\
\text { conti- } \\
\text { nence) }\end{array}$ \\
\hline $\begin{array}{l}\text { Leroi } \\
2005 \#\end{array}$ & $\begin{array}{l}\text { Group } \\
\text { of } 19 \text { who } \\
\text { chose 'on' } \\
\text { following } \\
\text { the } \\
\text { crossover } \\
\text { period }\end{array}$ & $\begin{array}{l}\text { Median } \\
\text { (range) }\end{array}$ & $\begin{array}{l}\text { Baseline: } \\
18 \\
3 \\
\text { months: } \\
13 \\
\text { 'Off' pe- } \\
\text { riod: } 12 \\
\text { 'On' pe- } \\
\text { riod: } 14 \\
\text { Follow- } \\
\text { up: } 18\end{array}$ & $\begin{array}{l}16 \text { (8 to } \\
20)\end{array}$ & $\begin{array}{l}8 \quad(0 \text { to } \\
15)\end{array}$ & $\begin{array}{l}10 \text { (4 to } \\
17)\end{array}$ & $\begin{array}{l}8 \quad(3 \text { to } \\
15)\end{array}$ & $-2(-20 \%)$ & $\begin{array}{l}10 \text { (3 to } \\
17)\end{array}$ & $\begin{array}{l}1 . \quad P \\
<0.05: 3 \\
\text { months, } \\
\text { 'off' pe- } \\
\text { riod, 'on' } \\
\text { period, } \\
\text { follow- } \\
\text { up versus } \\
\text { baseline }\end{array}$ \\
\hline $\begin{array}{l}\text { Leroi } \\
2005 \#\end{array}$ & $\begin{array}{l}\text { Group } \\
\text { of } 5 \text { who } \\
\text { chose } \\
\text { 'off' fol- } \\
\text { lowing } \\
\text { the } \\
\text { crossover } \\
\text { period }\end{array}$ & $\begin{array}{l}\text { Median } \\
\text { (range) }\end{array}$ & $\begin{array}{l}\text { Baseline: } \\
5 \\
3 \\
\text { months: } \\
3 \\
\text { 'Off' pe- } \\
\text { riod: } 3 \\
\text { 'On' pe- } \\
\text { riod: } 3 \\
\text { Follow- } \\
\text { up: } 3\end{array}$ & $\begin{array}{l}16 \text { (12 to } \\
20)\end{array}$ & $\begin{array}{l}14 \text { (9 to } \\
19)\end{array}$ & $\begin{array}{l}15 \text { (11 to } \\
15)\end{array}$ & $\begin{array}{l}15 \text { (14 to } \\
18)\end{array}$ & 0 & $\begin{array}{l}13 \text { (11 to } \\
18)\end{array}$ & \\
\hline
\end{tabular}


Cleveland Clinic Incontinence Score (Continued)

\begin{tabular}{|c|c|c|c|c|c|c|c|c|c|}
\hline $\begin{array}{l}\text { Thin } \\
2015\end{array}$ & $\begin{array}{l}\text { PTNS } \\
\text { group }\end{array}$ & Mean \pm SD & 16 & $15.1 \pm 2.7$ & $11.7 \pm 4.4$ & & $\begin{array}{l}-3 \\
20 \%)\end{array}$ & $12.1 \pm 5.2$ & $\begin{array}{l}\text { Follow- } \\
\text { up was at } \\
6 \\
\text { months. } \\
\% \text { change } \\
\text { is re- } \\
\text { ported as } \\
\text { the differ- } \\
\text { ence be- } \\
\text { tween } \\
\text { baseline } \\
\text { and at } 6 \\
\text { months }\end{array}$ \\
\hline $\begin{array}{l}\text { Thin } \\
2015\end{array}$ & $\begin{array}{l}\text { SNS } \\
\text { group }\end{array}$ & Mean \pm SD & 15 & $16.3 \pm 3.3$ & $10.0 \pm 5.3$ & & $\begin{array}{l}-7.2(- \\
44 \%)\end{array}$ & $9.1 \pm 5.4$ & $\begin{array}{l}\text { Follow- } \\
\text { up was at } \\
6 \\
\text { months. } \\
\% \text { change } \\
\text { is re- } \\
\text { ported as } \\
\text { the differ- } \\
\text { ence be- } \\
\text { tween } \\
\text { baseline } \\
\text { and at } 6 \\
\text { months }\end{array}$ \\
\hline \multicolumn{10}{|l|}{$\begin{array}{l}\text { Thin } \\
2015\end{array}$} \\
\hline $\begin{array}{l}\text { Tjandra } \\
2008\end{array}$ & $\begin{array}{l}\text { Control } \\
\text { group }\end{array}$ & Mean \pm SD & 60 & $15.2 \pm 1.6$ & $12.1 \pm 2.1$ & $14.1+1.9$ & $\begin{array}{l}-1.1 \\
7 \%)\end{array}$ & $14.1 \pm 1.9$ & $\begin{array}{l}\mathrm{p}>0 . \\
05 \text { at } 3 \\
\text { months } \\
\text { and } 12 \\
\text { months } \\
\text { com- } \\
\text { pared } \\
\text { with } \\
\text { baseline. } \\
\text { Follow- } \\
\text { up was } \\
\text { at } 12 \\
\text { months. } \\
\% \text { change } \\
\text { is re- } \\
\text { ported }\end{array}$ \\
\hline
\end{tabular}


Cleveland Clinic Incontinence Score (Continued)

\begin{tabular}{|c|c|c|c|c|c|c|c|c|c|}
\hline & & & & & & & & & $\begin{array}{l}\text { as the } \\
\text { difference } \\
\text { between } \\
\text { baseline } \\
\text { and at } 12 \\
\text { months }\end{array}$ \\
\hline $\begin{array}{l}\text { Tjandra } \\
2008\end{array}$ & $\begin{array}{l}\text { SNS } \\
\text { group }\end{array}$ & Mean \pm SD & 53 & $16 \pm 1.3$ & $1.1 \pm 1$ & $1.2+1.8$ & $\begin{array}{l}-14.8 \\
93 \%)\end{array}$ & $1.2 \pm 1.8$ & $\begin{array}{l}\mathrm{P}<0 . \\
0001 \quad \text { at } \\
\text { all time } \\
\text { points } \\
\text { com- } \\
\text { pared } \\
\text { with } \\
\text { baseline. } \\
\text { Follow- } \\
\text { up was } \\
\text { at } 12 \\
\text { months. } \\
\% \text { change } \\
\text { is re- } \\
\text { ported } \\
\text { as the } \\
\text { difference } \\
\text { between } \\
\text { baseline } \\
\text { and at } 12 \\
\text { months }\end{array}$ \\
\hline $\begin{array}{l}\text { Tjandra } \\
2008\end{array}$ & & & & & & & & & \\
\hline
\end{tabular}

Analysis 3.7. Comparison 3 Faecal incontinence: crossover trials, Outcome 7 Quality of life - SF36.

Quality of life - SF36

\begin{tabular}{|c|c|c|c|c|c|c|c|c|c|c|}
\hline Study & Group & Measure & $\begin{array}{l}\text { Role- } \\
\text { emo- } \\
\text { tional }\end{array}$ & $\begin{array}{l}\text { General } \\
\text { health }\end{array}$ & $\begin{array}{l}\text { Mental } \\
\text { health }\end{array}$ & $\begin{array}{l}\text { Bodily } \\
\text { pain }\end{array}$ & $\begin{array}{l}\text { Phys- } \\
\text { ical func- } \\
\text { tioning }\end{array}$ & $\begin{array}{l}\text { Role- } \\
\text { physical }\end{array}$ & $\begin{array}{l}\text { Social } \\
\text { function }\end{array}$ & Vitality \\
\hline $\begin{array}{l}\text { Thin } \\
2015\end{array}$ & $\begin{array}{l}\text { SNS }(3 \\
\text { months) : } \\
\mathrm{n}=15\end{array}$ & $\begin{array}{l}\text { Mean } \\
(95 \% \mathrm{CI})\end{array}$ & $\begin{array}{l}11.1(-19 . \\
8 \text { to } 42.1)\end{array}$ & $\begin{array}{l}-6.8(-20 . \\
2 \text { to } 6.7)\end{array}$ & $\begin{array}{l}-2.7(-13 . \\
8 \text { to } 8.4)\end{array}$ & $\begin{array}{l}2.7(-15.7 \\
\text { to } 21.0)\end{array}$ & $\begin{array}{l}-9.8(-24 . \\
2 \text { to } 4.7)\end{array}$ & $\begin{array}{l}26.7(3.6 \\
\text { to } 49.8)\end{array}$ & $\begin{array}{l}19.1(3.7 \\
\text { to } 34.6)\end{array}$ & $\begin{array}{l}2.7 \quad(-8.9 \\
\text { to } 14.3)\end{array}$ \\
\hline $\begin{array}{l}\text { Thin } \\
2015\end{array}$ & $\begin{array}{l}\text { PTNS (3 } \\
\text { months) } \\
\mathrm{n}=16\end{array}$ & $\begin{array}{l}\text { Mean } \\
(95 \% \mathrm{CI})\end{array}$ & $\begin{array}{l}20 \\
0(-15.4 \\
\text { to } 55.4)\end{array}$ & $\begin{array}{l}-4.0(-12 . \\
1 \text { to } 4.1)\end{array}$ & $\begin{array}{l}8.3 \quad(1.2 \\
\text { to } 15.3)\end{array}$ & $\begin{array}{l}-5.5(-20 . \\
5 \text { to } 9.5)\end{array}$ & $\begin{array}{l}9.1 \quad(-3.4 \\
\text { to } 21.7)\end{array}$ & $\begin{array}{l}6.7(-23.6 \\
\text { to } 36.9)\end{array}$ & $\begin{array}{l}13.3(1.2 \\
\text { to } 25.5)\end{array}$ & $\begin{array}{l}2.0 \quad(-3.7 \\
\text { to } 7.7)\end{array}$ \\
\hline
\end{tabular}


Quality of life - SF36 (Continued)

\begin{tabular}{|c|c|c|c|c|c|c|c|c|c|c|}
\hline $\begin{array}{l}\text { Thin } \\
2015\end{array}$ & $\begin{array}{l}\text { SNS ( } 6 \\
\text { months) } \\
\mathrm{n}=15\end{array}$ & $\begin{array}{l}\text { Mean } \\
(95 \% \mathrm{CI})\end{array}$ & $\begin{array}{l}17.8(-12 . \\
5 \text { to } 48.1 \\
)\end{array}$ & $\begin{array}{l}-4.8(-15 . \\
4 \text { to } 5.8)\end{array}$ & $\begin{array}{l}1.7(-12 . \\
2 \text { to } 15.5)\end{array}$ & $\begin{array}{l}7.2(-12.7 \\
\text { to } 27.0)\end{array}$ & $\begin{array}{l}-9.1(-25 . \\
4 \text { to } 7.3)\end{array}$ & $\begin{array}{l}25.0(-5.5 \\
\text { to } 55.5)\end{array}$ & $\begin{array}{l}17.5(-0.4 \\
\text { to } 35.4)\end{array}$ & $\begin{array}{l}8.7(-4.3 \\
\text { to } 21.6)\end{array}$ \\
\hline $\begin{array}{l}\text { Thin } \\
2015\end{array}$ & $\begin{array}{l}\text { PTNS ( } 6 \\
\text { months) } \\
\mathrm{n}=16\end{array}$ & $\begin{array}{l}\text { Mean } \\
(95 \% \text { CI })\end{array}$ & $\begin{array}{l}16.7(-0.5 \\
\text { to } 33.8)\end{array}$ & $\begin{array}{l}-7.5(-14 \\
7 \text { to }-0.3)\end{array}$ & $\begin{array}{l}10.5(5.1 \\
\text { to } 15.9)\end{array}$ & $\begin{array}{l}0.9(-8.8 \\
\text { to } 10.6)\end{array}$ & $\begin{array}{l}9.1 \quad(-3.3 \\
\text { to } 21.4)\end{array}$ & $\begin{array}{l}0.0(-22.3 \\
\text { to } 22.3)\end{array}$ & $\begin{array}{l}10.9(-0.7 \\
\text { to } 22.6)\end{array}$ & $\begin{array}{l}0.0 \quad(-8.9 \\
\text { to } 8.9)\end{array}$ \\
\hline $\begin{array}{l}\text { Vaizey } \\
2000 \#\end{array}$ & Baseline & $\begin{array}{l}\text { Mean } \\
\text { (range) }\end{array}$ & $\begin{array}{l}33 \text { (only } \\
\text { recorded } \\
\text { for } \\
\text { one par- } \\
\text { ticipant) }\end{array}$ & $\begin{array}{l}79 \text { (72 to } \\
86)\end{array}$ & $\begin{array}{l}70(64 \text { to } \\
76)\end{array}$ & $\begin{array}{l}52(30 \text { to } \\
74)\end{array}$ & $\begin{array}{l}71 \text { (70 to } \\
72)\end{array}$ & $\begin{array}{l}38 \quad(0 \text { to } \\
75)\end{array}$ & $\begin{array}{l}44(12 \text { to } \\
75)\end{array}$ & $\begin{array}{l}40(10 \text { to } \\
70)\end{array}$ \\
\hline $\begin{array}{l}\text { Vaizey } \\
2000 \#\end{array}$ & $\begin{array}{l}\text { Nine } \\
\text { months }\end{array}$ & $\begin{array}{l}\text { Mean } \\
\text { (range) }\end{array}$ & $\begin{array}{l}83 \text { (66 to } \\
100)\end{array}$ & $\begin{array}{l}92 \text { (both } \\
92 \text { ) }\end{array}$ & $\begin{array}{l}80(72 \text { to } \\
88)\end{array}$ & $\begin{array}{l}92(84 \text { to } \\
100)\end{array}$ & $\begin{array}{l}83 \text { (80 to } \\
85)\end{array}$ & $\begin{array}{l}100 \text { (both } \\
100)\end{array}$ & $\begin{array}{l}88(75 \text { to } \\
100)\end{array}$ & $\begin{array}{l}75 \text { (70 to } \\
80)\end{array}$ \\
\hline
\end{tabular}

Analysis 3.8. Comparison 3 Faecal incontinence: crossover trials, Outcome 8 Quality of life - SF I 2.

Quality of life - SF12

\begin{tabular}{|c|c|c|c|c|c|c|c|c|}
\hline Study & Group & Scale & Measure & Patients & Baseline & 3 months & 12 months & Notes \\
\hline $\begin{array}{l}\text { Tjandra } \\
2008\end{array}$ & Control & $\begin{array}{l}\text { Physical } \\
\text { health }\end{array}$ & Mean \pm SD & 60 & $39.29 \pm 12.12$ & $41.5 \pm 9.89$ & $40.5 \pm 10.2$ & $\begin{array}{l}\mathrm{P}>0.05 \\
\text { at } 3 \text { months and } \\
12 \text { months com- } \\
\text { pared with base- } \\
\text { line. }\end{array}$ \\
\hline $\begin{array}{l}\text { Tjandra } \\
2008\end{array}$ & & $\begin{array}{l}\text { Mental } \\
\text { health }\end{array}$ & Mean \pm SD & 60 & $45.38 \pm 12.32$ & $47.82 \pm 10.66$ & $48.22 \pm 10.12$ & $\begin{array}{l}\mathrm{P}>0.05 \\
\text { at } 3 \text { months and } \\
12 \text { months com- } \\
\text { pared with base- } \\
\text { line. }\end{array}$ \\
\hline $\begin{array}{l}\text { Tjandra } \\
2008\end{array}$ & SNS & $\begin{array}{l}\text { Physical } \\
\text { health }\end{array}$ & Mean \pm SD & 53 & $39.81 \pm 11.14$ & $43.18 \pm 11.68$ & $42.22 \pm 9.25$ & $\begin{array}{l}\mathrm{P}>0.025 \text { at all } \\
\text { time points. }\end{array}$ \\
\hline $\begin{array}{l}\text { Tjandra } \\
2008\end{array}$ & & $\begin{array}{l}\text { Mental } \\
\text { health }\end{array}$ & Mean \pm SD & 53 & $45.25 \pm 11.09$ & $50.16 \pm 10.41$ & $49.22 \pm 10.88$ & $\begin{array}{l}\mathrm{P}>0.025 \text { at } \\
12 \text { months. How- } \\
\text { ever, } \mathrm{p}=0.005 \text { at } \\
3 \text { months. }\end{array}$ \\
\hline
\end{tabular}


Analysis 3.9. Comparison 3 Faecal incontinence: crossover trials, Outcome 9 Quality of life - modified ASCRS.

Quality of life - modified ASCRS

\begin{tabular}{|c|c|c|c|c|c|c|c|c|}
\hline Study & Group & Measure & Patients & Lifestyle & $\begin{array}{l}\text { Coping/ } \\
\text { behaviour }\end{array}$ & $\begin{array}{l}\text { Depression/ } \\
\text { self-perc }\end{array}$ & $\begin{array}{l}\text { Embarrass- } \\
\text { ment }\end{array}$ & Notes \\
\hline Leroi 2005\# & Baseline & $\begin{array}{l}\text { Median } \\
\text { (range) }\end{array}$ & $34 ?$ & 1.7 (1 to 3.8$)$ & 1.5 (1 to 2.8$)$ & $2.2(1$ to 4.1$)$ & 1.3 (1 to 3$)$ & $\begin{array}{l}\text { The ASCRS } \\
\text { ranges from a } \\
\text { best score of } \\
5 \text { to a worst } \\
\text { score of } 1\end{array}$ \\
\hline Leroi 2005\# & Follow-up & $\begin{array}{l}\text { Median } \\
\text { (range) }\end{array}$ & $24 ?$ & $\begin{array}{l}3.2(1.9 \text { to } 4) \\
\mathrm{P}=0.001 \text { ver- } \\
\text { sus baseline }\end{array}$ & $\begin{array}{l}2.7(1 \text { to } 4) \\
\mathrm{P}=0.002 \text { ver- } \\
\text { sus baseline }\end{array}$ & $\begin{array}{l}3.6 \text { ( } 1.8 \text { to } 4 . \\
\text { 2) } \\
\mathrm{P}=0.009 \text { ver- } \\
\text { sus baseline }\end{array}$ & $\begin{array}{l}2.3(1 \text { to } 4) \\
\mathrm{P}=0.002 \text { ver- } \\
\text { sus baseline }\end{array}$ & \\
\hline
\end{tabular}

Analysis 3.10. Comparison 3 Faecal incontinence: crossover trials, Outcome I0 Quality of life - ASCRS FIQL.

Quality of life - ASCRS FIQL

\begin{tabular}{|c|c|c|c|c|c|c|c|c|c|}
\hline Study & Group & Period & Measure & Patients & Lifestyle & $\begin{array}{l}\text { Coping/ } \\
\text { behaviour }\end{array}$ & $\begin{array}{l}\text { Depres- } \\
\text { sion/self- } \\
\text { perception }\end{array}$ & $\begin{array}{l}\text { Embarrass- } \\
\text { ment }\end{array}$ & Notes \\
\hline $\begin{array}{l}\text { Tjandra } \\
2008\end{array}$ & Control & Baseline & Mean \pm SD & 60 & $2.26 \pm 0.98$ & $1.79 \pm 0.82$ & $2.59 \pm 0.72$ & $1.81 \pm 0.52$ & \\
\hline $\begin{array}{l}\text { Tjandra } \\
2008\end{array}$ & & 3 months & Mean \pm SD & 60 & $2.12 \pm 0.91$ & $1.85 \pm 0.92$ & $2.68 \pm 0.65$ & $1.7 \pm 0.67$ & $\begin{array}{l}\mathrm{P}>0.05 \text { at } 3 \\
\text { months and } \\
12 \text { months } \\
\text { com- } \\
\text { pared with } \\
\text { baseline. }\end{array}$ \\
\hline $\begin{array}{l}\text { Tjandra } \\
2008\end{array}$ & & 12 months & Mean \pm SD & 60 & $2.31 \pm 0.89$ & $1.86 \pm 0.88$ & $2.64 \pm 0.84$ & $1.78 \pm 0.61$ & $\begin{array}{l}P>0.05 \text { at } 3 \\
\text { months and } \\
12 \text { months } \\
\text { com- } \\
\text { pared with } \\
\text { baseline. }\end{array}$ \\
\hline $\begin{array}{l}\text { Tjandra } \\
2008\end{array}$ & SNS & Baseline & Mean \pm SD & 53 & $2.39 \pm 0.99$ & $1.89 \pm 0.82$ & $2.65 \pm 0.84$ & $1.93 \pm 0.78$ & \\
\hline $\begin{array}{l}\text { Tjandra } \\
2008\end{array}$ & & 3 months & Mean \pm SD & 53 & $3.34 \pm 0.72$ & $2.87 \pm 0.8$ & $3.31 \pm 0.77$ & $2.89 \pm 0.85$ & $\begin{array}{l}\mathrm{P}< \\
0.0001 \text { at } 3\end{array}$ \\
\hline
\end{tabular}


Quality of life - ASCRS FIQL (Continued)

\begin{tabular}{|c|c|c|c|c|c|c|c|c|}
\hline & & & & & & & & $\begin{array}{l}\text { months and } \\
12 \text { months } \\
\text { com- } \\
\text { pared with } \\
\text { baseline. }\end{array}$ \\
\hline $\begin{array}{l}\text { Tjandra } \\
2008\end{array}$ & 12 months & Mean \pm SD & 53 & $3.31 \pm 0.72$ & $2.68 \pm 0.87$ & $3.25 \pm 0.8$ & $2.76 \pm 0.94$ & $\begin{array}{l}\mathrm{P} \quad< \\
0.0001 \text { at } 3 \\
\text { months and } \\
12 \text { months } \\
\text { com- } \\
\text { pared with } \\
\text { baseline. }\end{array}$ \\
\hline
\end{tabular}

Analysis 3.I I. Comparison 3 Faecal incontinence: crossover trials, Outcome I I Anorectal manometry. Anorectal manometry

\begin{tabular}{|c|c|c|c|c|c|c|c|c|}
\hline Study & Group & Measure & Patients & Baseline & $\begin{array}{l}\text { 'Off' } \\
\text { period }\end{array}$ & 'On' period & Follow-up & Notes \\
\hline \multicolumn{9}{|c|}{ Maximal resting pressure $(\mathrm{cm} \mathrm{H} 20)$} \\
\hline Leroi 2005\# & $\begin{array}{l}\text { Group of } 19 \\
\text { who chose } \\
\text { 'on' follow- } \\
\text { ing } \\
\text { the crossover } \\
\text { period }\end{array}$ & $\begin{array}{l}\text { Median } \\
\text { (range) }\end{array}$ & $\begin{array}{l}\text { Baseline: } 19 \\
\text { 'Off 'period: } \\
13 \\
\text { 'On' period: } \\
17 \\
\text { Follow-up: } \\
18\end{array}$ & $\begin{array}{l}40 \quad(12 \text { to } \\
109)\end{array}$ & $\begin{array}{l}37 \quad(26 \text { to } \\
100)\end{array}$ & $\begin{array}{l}50 \quad(27 \quad \text { to } \\
155)\end{array}$ & $\begin{array}{l}60 \quad(30 \quad \text { to } \\
96)\end{array}$ & $\begin{array}{l}\mathrm{P}<0 . \\
05: \text { 'on' pe- } \\
\text { riod versus } \\
\text { baseline; fol- } \\
\text { low-up ver- } \\
\text { sus baseline; } \\
\text { 'off' period } \\
\text { versus } \\
\text { follow-up }\end{array}$ \\
\hline Leroi 2005\# & $\begin{array}{l}\text { Group of } \\
5 \text { who chose } \\
\text { 'off' follow- } \\
\text { ing } \\
\text { the crossover } \\
\text { period }\end{array}$ & $\begin{array}{l}\text { Median } \\
\text { (range) }\end{array}$ & $\begin{array}{l}\text { Baseline: } 5 \\
\text { 'Off' } \\
\text { period: } 5 \\
\text { 'On' period: } \\
5 \\
\text { Follow-up: } \\
5\end{array}$ & $\begin{array}{ll}40 \quad(20 \quad \text { to } \\
90) & \end{array}$ & $\begin{array}{lll}50 \quad(39 & \text { to } \\
98) & & \end{array}$ & $\begin{array}{ll}64 \quad(37 \quad \text { to } \\
98)\end{array}$ & $\begin{array}{l}50 \quad(31 \text { to } \\
100)\end{array}$ & \\
\hline $\begin{array}{l}\text { Sørensen } \\
2010 \#\end{array}$ & & $\begin{array}{l}\text { Mean } \\
(95 \% \text { CI for } \\
\text { mean) }\end{array}$ & 7 & & $\begin{array}{l}106.2(71.1- \\
141.4)\end{array}$ & $\begin{array}{l}84.2 \quad(70.4- \\
98.3)\end{array}$ & & \\
\hline
\end{tabular}

Sørensen

2010\#

Sacral nerve stimulation for faecal incontinence and constipation in adults (Review) 
Anorectal manometry (Continued)

\begin{tabular}{|c|c|c|c|c|c|c|c|c|}
\hline $\begin{array}{l}\text { Tjandra } \\
2008\end{array}$ & Control & Mean \pm SD & 60 & $42.4 \pm 15.2$ & & & & $\begin{array}{l}\text { Only } \\
\text { performed } \\
\text { at baseline. }\end{array}$ \\
\hline $\begin{array}{l}\text { Tjandra } \\
2008\end{array}$ & SNS & Mean $\pm S D$ & 53 & $40.4 \pm 15.9$ & & & $40.9 \pm 21.9$ & $\begin{array}{l}\mathrm{P}>0 . \\
05 \text { at all time } \\
\text { points com- } \\
\text { pared with } \\
\text { base- } \\
\text { line. Follow- } \\
\text { up was at } 12 \\
\text { months }\end{array}$ \\
\hline $\begin{array}{l}\text { Vaizey } \\
2000 \#\end{array}$ & & $\begin{array}{l}\text { Mean } \\
\text { (range) }\end{array}$ & 2 & $\begin{array}{l}38(35 \text { and } \\
40)\end{array}$ & $\begin{array}{l}43(35 \text { and } \\
50)\end{array}$ & $\begin{array}{l}58(45 \text { and } \\
70)\end{array}$ & & \\
\hline $\begin{array}{l}\text { Vaizey } \\
2000 \#\end{array}$ & & & & & & & & \\
\hline
\end{tabular}

Maximal squeeze pressure (cm H20)

\begin{tabular}{|c|c|c|c|c|c|c|c|c|}
\hline Leroi 2005\# & $\begin{array}{l}\text { Group of } 19 \\
\text { who chose } \\
\text { 'on' follow- } \\
\text { ing } \\
\text { the crossover } \\
\text { period }\end{array}$ & $\begin{array}{l}\text { Median } \\
\text { (range) }\end{array}$ & $\begin{array}{l}\text { Baseline: } 19 \\
\text { 'Off' } \\
\text { period: } 13 \\
\text { 'On' period: } \\
17 \\
\text { Follow-up: } \\
19\end{array}$ & $\begin{array}{ll}30 \quad(0 \quad \text { to } \\
270)\end{array}$ & $\begin{array}{ll}49 \quad(10 \quad \text { to } \\
98)\end{array}$ & $\begin{array}{l}53 \quad(6 \quad \text { to } \\
326)\end{array}$ & $\begin{array}{lll}50 \quad(0 \quad \text { to } \\
213)\end{array}$ & $\begin{array}{l}\mathrm{P}<0.05 \text { : fol- } \\
\text { low-up ver- } \\
\text { sus baseline }\end{array}$ \\
\hline Leroi 2005\# & $\begin{array}{l}\text { Group of } \\
5 \text { who chose } \\
\text { 'off' follow- } \\
\text { ing } \\
\text { the crossover } \\
\text { period }\end{array}$ & $\begin{array}{l}\text { Median } \\
\text { (range) }\end{array}$ & $\begin{array}{l}\text { Baseline: } 5 \\
\text { 'Off' } \\
\text { period: } 5 \\
\text { 'On' period: } \\
5 \\
\text { Follow-up: } \\
5\end{array}$ & $\begin{array}{lll}30 & (23 \quad \text { to } \\
90) & & \end{array}$ & $\begin{array}{l}54 \quad(37 \quad \text { to } \\
110)\end{array}$ & $\begin{array}{ll}30 \quad(21 \quad \text { to } \\
90)\end{array}$ & $\begin{array}{l}30 \quad(20 \text { to } \\
140)\end{array}$ & \\
\hline $\begin{array}{l}\text { Sørensen } \\
2010 \#\end{array}$ & & $\begin{array}{l}\text { Mean } \\
(95 \% \text { CI for } \\
\text { mean) }\end{array}$ & 7 & & $\begin{array}{l}223.0(153 . \\
7 \text { to } 292.4)\end{array}$ & $\begin{array}{l}223.0(159 . \\
1 \text { to } 287.0)\end{array}$ & & \\
\hline \multicolumn{9}{|l|}{$\begin{array}{l}\text { Sørensen } \\
2010 \#\end{array}$} \\
\hline $\begin{array}{l}\text { Tjandra } \\
2008\end{array}$ & $\begin{array}{l}\text { Control } \\
\text { group }\end{array}$ & Mean \pm SD & 60 & $88.5 \pm 42.6$ & & & & $\begin{array}{l}\text { Only } \\
\text { performed } \\
\text { at baseline. }\end{array}$ \\
\hline
\end{tabular}


Anorectal manometry (Continued)

\begin{tabular}{|c|c|c|c|c|c|c|c|c|}
\hline $\begin{array}{l}\text { Tjandra } \\
2008\end{array}$ & SNS group & Mean \pm SD & 53 & $83.2 \pm 39.6$ & & & $90.2 \pm 54.9$ & $\begin{array}{l}\mathrm{P}>0 . \\
05 \text { at all time } \\
\text { points com- } \\
\text { pared with } \\
\text { base- } \\
\text { line. Follow- } \\
\text { up was at } 12 \\
\text { months }\end{array}$ \\
\hline $\begin{array}{l}\text { Vaizey } \\
2000 \#\end{array}$ & & $\begin{array}{l}\text { Mean } \\
\text { (range) }\end{array}$ & 2 & $\begin{array}{l}100 \text { (80 and } \\
120)\end{array}$ & $\begin{array}{l}65(60 \text { and } \\
70)\end{array}$ & $\begin{array}{l}95(90 \text { and } \\
100)\end{array}$ & & \\
\hline $\begin{array}{l}\text { Vaizey } \\
2000 \#\end{array}$ & & & & & & & & \\
\hline
\end{tabular}

Squeeze pressure duration (seconds)

\begin{tabular}{|c|c|c|c|c|c|c|c|}
\hline Leroi 2005\# & $\begin{array}{l}\text { Group of } 19 \\
\text { who chose } \\
\text { 'on' follow- } \\
\text { ing } \\
\text { the crossover } \\
\text { period }\end{array}$ & $\begin{array}{l}\text { Median } \\
\text { (range) }\end{array}$ & $\begin{array}{l}\text { Baseline: } 19 \\
\text { 'Off' } \\
\text { period: } 13 \\
\text { 'On' period: } \\
17 \\
\text { Follow-up: } \\
19\end{array}$ & $15(0$ to 45$)$ & 21 (4 to 32$)$ & 18 (6 to 92$)$ & $\begin{array}{l}22 \quad(0 \quad \text { to } \\
110)\end{array}$ \\
\hline Leroi 2005\# & $\begin{array}{l}\text { Group of } \\
5 \text { who chose } \\
\text { 'off' follow- } \\
\text { ing } \\
\text { the crossover } \\
\text { period }\end{array}$ & $\begin{array}{l}\text { Median } \\
\text { (range) }\end{array}$ & $\begin{array}{l}\text { Baseline: } 5 \\
\text { 'Off' } \\
\text { period: } 5 \\
\text { 'On' period: } \\
5 \\
\text { Follow-up: } \\
5\end{array}$ & 20 (5 to 28$)$ & $40(5$ to 40$)$ & $\begin{array}{lll}32 & (23 \text { to } \\
38) & & \end{array}$ & $25(4$ to 40$)$ \\
\hline
\end{tabular}

Rectal volume sensation - threshold (ml)

\begin{tabular}{|c|c|c|c|c|c|c|c|}
\hline Leroi 2005\# & $\begin{array}{l}\text { Group of } 19 \\
\text { who chose } \\
\text { 'on' follow- } \\
\text { ing } \\
\text { the crossover } \\
\text { period }\end{array}$ & $\begin{array}{l}\text { Median } \\
\text { (range) }\end{array}$ & $\begin{array}{l}\text { Baseline: } 17 \\
\text { Follow-up: } \\
18\end{array}$ & $\begin{array}{l}25 \quad(10 \text { to } \\
120)\end{array}$ & $\begin{array}{l}\text { Not } \\
\text { reported }\end{array}$ & $\begin{array}{l}\text { Not } \\
\text { reported }\end{array}$ & $\begin{array}{l}30 \quad(10 \quad \text { to } \\
120)\end{array}$ \\
\hline Leroi 2005\# & $\begin{array}{l}\text { Group of } \\
5 \text { who chose } \\
\text { 'off' follow- } \\
\text { ing } \\
\text { the crossover } \\
\text { period }\end{array}$ & $\begin{array}{l}\text { Median } \\
\text { (range) }\end{array}$ & $\begin{array}{l}\text { Baseline: } 5 \\
\text { Follow-up: } \\
5\end{array}$ & $\begin{array}{l}10 \quad(10 \text { to } \\
40)\end{array}$ & $\begin{array}{l}\text { Not } \\
\text { reported }\end{array}$ & $\begin{array}{l}\text { Not } \\
\text { reported }\end{array}$ & $\begin{array}{l}10 \quad(10 \quad \text { to } \\
50)\end{array}$ \\
\hline
\end{tabular}


Anorectal manometry (Continued)

\begin{tabular}{|c|c|c|c|c|c|}
\hline $\begin{array}{l}\text { Sørensen } \\
2010 \#\end{array}$ & $\begin{array}{l}\text { Mean } \\
(95 \% \text { CI for } \\
\text { mean) }\end{array}$ & 7 & & $\begin{array}{l}50.0 \quad(34.6 \\
\text { to } 65.4)\end{array}$ & $\begin{array}{l}27.1 \quad(17.8 \\
\text { to } 36.4)\end{array}$ \\
\hline \multicolumn{6}{|l|}{$\begin{array}{l}\text { Sørensen } \\
2010 \#\end{array}$} \\
\hline $\begin{array}{l}\text { Vaizey } \\
2000 \#\end{array}$ & $\begin{array}{l}\text { Mean } \\
\text { (range) }\end{array}$ & 2 & 45 (both 45) & $\begin{array}{l}38(25 \text { and } \\
50)\end{array}$ & $\begin{array}{l}68 \text { (45 and } \\
90)\end{array}$ \\
\hline $\begin{array}{l}\text { Vaizey } \\
2000 \#\end{array}$ & & & & & \\
\hline
\end{tabular}

Rectal volume sensation - urge $(\mathrm{ml})$

\begin{tabular}{|c|c|c|c|c|c|}
\hline $\begin{array}{l}\text { Sørensen } \\
2010 \#\end{array}$ & $\begin{array}{l}\text { Mean } \\
(95 \% \text { CI for } \\
\text { mean })\end{array}$ & 7 & & $\begin{array}{l}82.9 \quad(64.8 \\
\text { to } 101)\end{array}$ & $\begin{array}{l}60(48.7 \text { to } \\
71.3)\end{array}$ \\
\hline \multicolumn{6}{|l|}{$\begin{array}{l}\text { Sørensen } \\
2010 \#\end{array}$} \\
\hline $\begin{array}{l}\text { Vaizey } \\
2000 \#\end{array}$ & $\begin{array}{l}\text { Mean } \\
\text { (range) }\end{array}$ & 2 & $\begin{array}{l}68 \quad(65 \text { and } \\
70)\end{array}$ & $\begin{array}{l}85(70 \text { and } \\
100)\end{array}$ & $\begin{array}{l}103 \text { (85 and } \\
120)\end{array}$ \\
\hline $\begin{array}{l}\text { Vaizey } \\
2000 \#\end{array}$ & & & & & \\
\hline
\end{tabular}

Rectal volume sensation - maximal tolerated $(\mathrm{ml})$

\begin{tabular}{|c|c|c|c|c|c|c|c|}
\hline Leroi 2005\# & $\begin{array}{l}\text { Group of } 19 \\
\text { who chose } \\
\text { 'on' follow- } \\
\text { ing } \\
\text { the crossover } \\
\text { period }\end{array}$ & $\begin{array}{l}\text { Median } \\
\text { (range) }\end{array}$ & $\begin{array}{l}\text { Baseline: } 17 \\
\text { Follow-up: } \\
17\end{array}$ & $\begin{array}{l}185 \text { (80 to } \\
350)\end{array}$ & $\begin{array}{l}\text { Not } \\
\text { reported }\end{array}$ & $\begin{array}{l}\text { Not } \\
\text { reported }\end{array}$ & $\begin{array}{l}170 \quad(40 \text { to } \\
275)\end{array}$ \\
\hline Leroi 2005\# & $\begin{array}{l}\text { Group of } \\
5 \text { who chose } \\
\text { 'off' follow- } \\
\text { ing } \\
\text { the crossover } \\
\text { period }\end{array}$ & $\begin{array}{l}\text { Median } \\
\text { (range) }\end{array}$ & $\begin{array}{l}\text { Baseline: } 5 \\
\text { Follow-up: } \\
5\end{array}$ & $\begin{array}{l}200 \quad(80 \text { to } \\
300)\end{array}$ & $\begin{array}{l}\text { Not } \\
\text { reported }\end{array}$ & $\begin{array}{l}\text { Not } \\
\text { reported }\end{array}$ & $\begin{array}{l}195 \text { (100 to } \\
300)\end{array}$ \\
\hline $\begin{array}{l}\text { Sørensen } \\
2010 \#\end{array}$ & & $\begin{array}{l}\text { Mean } \\
(95 \% \text { CI for } \\
\text { mean })\end{array}$ & 7 & & $\begin{array}{l}124 \text { (106 to } \\
142)\end{array}$ & $\begin{array}{l}124(82.4 \text { to } \\
165.6)\end{array}$ & \\
\hline
\end{tabular}


Anorectal manometry (Continued)

\begin{tabular}{|c|c|c|c|c|c|c|c|}
\hline $\begin{array}{l}\text { Sørensen } \\
2010 \#\end{array}$ & & & & & & & \\
\hline $\begin{array}{l}\text { Vaizey } \\
2000 \#\end{array}$ & & $\begin{array}{l}\text { Mean } \\
\text { (range) }\end{array}$ & 2 & $\begin{array}{l}118 \text { (95 and } \\
140)\end{array}$ & $\begin{array}{l}135 \quad(120 \\
\text { and } 150)\end{array}$ & $\begin{array}{l}140 \quad(130 \\
\text { and } 150)\end{array}$ & \\
\hline $\begin{array}{l}\text { Vaizey } \\
2000 \#\end{array}$ & & & & & & & \\
\hline Rectal volun & e sensation - c & onstant s & ion volume ( & & & & \\
\hline Leroi 2005\# & $\begin{array}{l}\text { Group of } 19 \\
\text { who chose } \\
\text { 'on' follow- } \\
\text { ing } \\
\text { the crossover } \\
\text { period }\end{array}$ & $\begin{array}{l}\text { Median } \\
\text { (range) }\end{array}$ & $\begin{array}{l}\text { Baseline: } 17 \\
\text { Follow-up: } \\
18\end{array}$ & $\begin{array}{l}100 \quad(40 \text { to } \\
230)\end{array}$ & $\begin{array}{l}\text { Not } \\
\text { reported }\end{array}$ & $\begin{array}{l}\text { Not } \\
\text { reported }\end{array}$ & $\begin{array}{l}85 \quad(30 \text { to } \\
300)\end{array}$ \\
\hline Leroi 2005\# & $\begin{array}{l}\text { Group of } \\
5 \text { who chose } \\
\text { 'off' follow- } \\
\text { ing } \\
\text { the crossover } \\
\text { period }\end{array}$ & $\begin{array}{l}\text { Median } \\
\text { (range) }\end{array}$ & $\begin{array}{l}\text { Baseline: } 5 \\
\text { Follow-up: } \\
5\end{array}$ & $\begin{array}{ll}50 \quad(20 \quad \text { to } \\
90)\end{array}$ & $\begin{array}{l}\text { Not } \\
\text { reported }\end{array}$ & $\begin{array}{l}\text { Not } \\
\text { reported }\end{array}$ & $\begin{array}{ll}50 \quad(20 \quad \text { to } \\
95)\end{array}$ \\
\hline
\end{tabular}

Analysis 3.12. Comparison 3 Faecal incontinence: crossover trials, Outcome I 2 Bowel movements per week.

Bowel movements per week

\begin{tabular}{|c|c|c|c|c|c|c|c|c|c|c|}
\hline Study & Group & Measure & Patients & Baseline & $\begin{array}{l}\text { Three } \\
\text { months }\end{array}$ & $\begin{array}{l}\text { 'Off' pe- } \\
\text { riod }\end{array}$ & $\begin{array}{l}\text { 'On' pe- } \\
\text { riod }\end{array}$ & $\begin{array}{l}\text { Change } \\
(\%)\end{array}$ & $\begin{array}{l}\text { Follow- } \\
\text { up }\end{array}$ & Notes \\
\hline $\begin{array}{l}\text { Kahlke } \\
\text { 2015\# }\end{array}$ & & $\begin{array}{l}\mathrm{Me} \text { an } \\
(\mathrm{SD})\end{array}$ & 14 & & & $18.2(8.7)$ & $10.9(4.1)$ & $\begin{array}{l}-7.3(-40 \\
\%)\end{array}$ & $9.4(2.6)$ & $p<0.05$ \\
\hline \multicolumn{11}{|l|}{$\begin{array}{l}\text { Kahlke } \\
\text { 2015\# }\end{array}$} \\
\hline $\begin{array}{l}\text { Leroi } \\
2005 \#\end{array}$ & $\begin{array}{l}\text { Group } \\
\text { of } 19 \text { who } \\
\text { chose 'on' } \\
\text { following } \\
\text { the } \\
\text { crossover } \\
\text { period }\end{array}$ & $\begin{array}{l}\text { Median } \\
\text { (range) }\end{array}$ & $\begin{array}{l}\text { Baseline: } \\
16 \\
3 \\
\text { months: } \\
15 \\
\text { 'Off' pe- } \\
\text { riod: } 18 \\
\text { 'On' pe- } \\
\text { riod: } 16 \\
\text { Follow- }\end{array}$ & $\begin{array}{l}11.5 \text { (6 to } \\
28)\end{array}$ & $\begin{array}{l}12 \text { (4 to } \\
27)\end{array}$ & $\begin{array}{l}10.6 \text { (6 to } \\
33)\end{array}$ & $\begin{array}{l}10.2(5 \text { to } \\
26)\end{array}$ & $\begin{array}{l}-0.4 \\
4 \%)\end{array}$ & $\begin{array}{l}10.6(7 \text { to } \\
37)\end{array}$ & $\begin{array}{l}1 . \\
\mathrm{P}<0.05 \text { : } \\
\text { 'on' ver- } \\
\text { sus 'off' } \\
\text { period. }\end{array}$ \\
\hline
\end{tabular}


Bowel movements per week (Continued)

up: 16

\begin{tabular}{|c|c|c|c|c|c|c|c|c|c|}
\hline $\begin{array}{l}\text { Leroi } \\
2005 \#\end{array}$ & $\begin{array}{l}\text { Group } \\
\text { of } 5 \text { who } \\
\text { chose } \\
\text { 'off' fol- } \\
\text { lowing } \\
\text { the } \\
\text { crossover } \\
\text { period }\end{array}$ & $\begin{array}{l}\text { Median } \\
\text { (range) }\end{array}$ & $\begin{array}{l}\text { Baseline: } \\
4 \\
3 \\
\text { months: } \\
4 \\
\text { 'Off' pe- } \\
\text { riod: } 5 \\
\text { 'On' pe- } \\
\text { riod: } 5 \\
\text { Follow- } \\
\text { up: } 5\end{array}$ & $\begin{array}{l}13.7 \text { (7 to } \\
30)\end{array}$ & $\begin{array}{l}10.6 \text { (8 to } \\
11)\end{array}$ & $\begin{array}{l}12.7 \text { (8 to } \\
19)\end{array}$ & $\begin{array}{l}11.2(7 \text { to } \\
32)\end{array}$ & $\begin{array}{l}-1.5 \\
12 \%)\end{array}$ & $\begin{array}{l}11.7 \text { (7 to } \\
32)\end{array}$ \\
\hline $\begin{array}{l}\text { Sørensen } \\
2010 \#\end{array}$ & & $\begin{array}{l}\text { Mean } \\
(95 \% \text { CI } \\
\text { for mean) }\end{array}$ & 7 & & & $\begin{array}{l}12 . \\
1(6.32 \text { to } \\
17.9)\end{array}$ & $\begin{array}{l}8.86 \quad(6 . \\
21 \text { to } 11 . \\
5)\end{array}$ & $\begin{array}{l}-3.24 \\
27 \%)\end{array}$ & \\
\hline
\end{tabular}

Sørensen

2010\#

Analysis 3.13. Comparison 3 Faecal incontinence: crossover trials, Outcome I 3 Soiling/week.

Soiling/week

\begin{tabular}{lllllllll}
\hline Study & Measure & & Patients & 'Off' period & 'On' period & Change (\%) & Notes \\
\hline Sørensen 2010\# & $\begin{array}{l}(95 \% \\
\text { mean })\end{array}$ & CI & for & 7 & $1.86(0.29-3.43)$ & $0.71(-0.69-2.11)$ & $-1.15(-62 \%)$ \\
\hline
\end{tabular}

Analysis 3.14. Comparison 3 Faecal incontinence: crossover trials, Outcome I4 Days with staining per week.

Days with staining per week

\begin{tabular}{|c|c|c|c|c|c|c|c|c|}
\hline Study & Group & Measure & Patients & Baseline & $\begin{array}{l}\text { Three } \\
\text { months }\end{array}$ & 12 months & Change (\%) & Notes \\
\hline $\begin{array}{l}\text { Tjandra } \\
2008\end{array}$ & $\begin{array}{l}\text { Control } \\
\text { group }\end{array}$ & Mean \pm SD & 60 & $4.3 \pm 1.9$ & $4.5 \pm 2.1$ & $4.5 \pm 2.3$ & $0.2(5 \%)$ & $\begin{array}{l}\mathrm{P}>0.05 \text { at } 3 \\
\text { months and } 12 \\
\text { months compared } \\
\text { with baseline. \% } \\
\text { change is reported } \\
\text { as the difference } \\
\text { between baseline } \\
\text { and at } 12 \text { months }\end{array}$ \\
\hline
\end{tabular}


Days with staining per week (Continued)

\begin{tabular}{|c|c|c|c|c|c|c|c|c|}
\hline $\begin{array}{l}\text { Tjandra } \\
2008\end{array}$ & SNS group & Mean \pm SD & 53 & $4 \pm 2.3$ & $1.3 \pm 1.7$ & $1.4 \pm 2$ & $-2.6(-65 \%)$ & $\begin{array}{l}\mathrm{P}<0.0001 \text { at all } \\
\text { time points com- } \\
\text { pared with base- } \\
\text { line. } \% \text { change is } \\
\text { reported as the dif- } \\
\text { ference between } \\
\text { baseline and at } 12 \\
\text { months }\end{array}$ \\
\hline
\end{tabular}

Analysis 3.15. Comparison 3 Faecal incontinence: crossover trials, Outcome I5 Days with incontinence per week.

Days with incontinence per week

\begin{tabular}{|c|c|c|c|c|c|c|c|c|}
\hline Study & Group & Measure & Patients & Baseline & $\begin{array}{l}\text { Three } \\
\text { months }\end{array}$ & 12 months & Change (\%) & Notes \\
\hline $\begin{array}{l}\text { Tjandra } \\
2008\end{array}$ & $\begin{array}{l}\text { Control } \\
\text { group }\end{array}$ & Mean \pm SD & 60 & $3.3 \pm 2.1$ & $2.9 \pm 2.4$ & $3.1 \pm 1.8$ & $-0.2(-6 \%)$ & $\begin{array}{l}\mathrm{P}>0.05 \text { at } 3 \\
\text { months and } 12 \\
\text { months compared } \\
\text { with baseline. \% } \\
\text { change is reported } \\
\text { as the difference } \\
\text { between baseline } \\
\text { and at } 12 \text { months }\end{array}$ \\
\hline $\begin{array}{l}\text { Tjandra } \\
2008\end{array}$ & SNS group & Mean \pm SD & 53 & $3.3 \pm 2.4$ & $1 \pm 1.7$ & $1 \pm 1.7$ & $-2.3(-70 \%)$ & $\begin{array}{l}\mathrm{P}<0.0001 \text { at all } \\
\text { time points com- } \\
\text { pared with base- } \\
\text { line. \% change is } \\
\text { reported as the dif- } \\
\text { ference between } \\
\text { baseline and at } 12 \\
\text { months }\end{array}$ \\
\hline
\end{tabular}

Analysis 3.16. Comparison 3 Faecal incontinence: crossover trials, Outcome 16 Passive leakage/week.

Passive leakage/week

\begin{tabular}{l|llllllll}
\hline Study & Measure & Patients & 'Off' period & 'On' period & Change (\%) & Notes \\
\hline Sørensen 2010\# & $\begin{array}{l}\left(\begin{array}{l}95 \% \\
\text { mean })\end{array}\right. \\
\text { CI }\end{array}$ & for 7 & $\begin{array}{l}0.43(-0.41 \quad \text { to } \\
27)\end{array}$ & 0 & $-0.43(-100 \%)$ \\
\hline
\end{tabular}


Analysis 4.I. Comparison 4 Constipation, Outcome I Bowel movements per week.

Bowel movements per week

\begin{tabular}{|c|c|c|c|c|c|c|c|c|}
\hline Study & Measure & Patients & Baseline & One year & 'Off' period & 'On' period & Change (\%) & Notes \\
\hline $\begin{array}{l}\text { Dinning } \\
2015 \#\end{array}$ & Mean (SD) & 53 & $3.6(2.0)$ & & $4.0(1.9)$ & $4.3(1.8)$ & $0.7(19 \%)$ & $\begin{array}{l}\text { Off } \\
\text { period is sham, } \\
\text { and on period } \\
\text { is suprasensory } \\
\text { stimulation }\end{array}$ \\
\hline $\begin{array}{l}\text { Kenefick } \\
2002 \#\end{array}$ & $\begin{array}{l}\text { Mean } \\
\text { (range) }\end{array}$ & 2 & $2(1$ and 3$)$ & 8 (8 and 9) & 2 (1 and 2$)$ & 5 (4 and 5) & $3(150 \%)$ & \\
\hline
\end{tabular}

Analysis 4.2. Comparison 4 Constipation, Outcome 2 Time with abdominal pain and bloating (\%).

Time with abdominal pain and bloating (\%)

\begin{tabular}{llllll|l|l|l|l}
\hline Study & Measure & Patients & Baseline & One year & 'Off' period & 'On' period & Change & Notes \\
\hline $\begin{array}{l}\text { Kenefick } \\
2002 \#\end{array}$ & $\begin{array}{l}\text { Mean } \\
\text { (range) }\end{array}$ & 2 & $\begin{array}{l}98 \quad(95 \text { and } \\
100)\end{array}$ & $\begin{array}{l}79 \quad(65 \text { and } \\
93)\end{array}$ & $33(0$ and 65$)$ & -46 & \\
\hline
\end{tabular}

Analysis 4.3. Comparison 4 Constipation, Outcome 3 Wexner Constipation Score.

Wexner Constipation Score

\begin{tabular}{|c|c|c|c|c|c|c|c|c|}
\hline Study & Measure & Patients & Baseline & One year & 'Off' period & 'On' period & Change (\%) & Notes \\
\hline $\begin{array}{l}\text { Kenefick } \\
2002 \#\end{array}$ & $\begin{array}{l}\text { Mean } \\
\text { (range) }\end{array}$ & 2 & 21 (20 to 22$)$ & $5(4$ to 6$)$ & $14(13$ to 15$)$ & $9(5$ to 13$)$ & $-5(-36 \%)$ & $\begin{array}{l}\text { The score } \\
\text { ranges from } 0 \\
\text { (normal) to } 30 \\
\text { (severe consti- } \\
\text { pation) }\end{array}$ \\
\hline
\end{tabular}

Analysis 4.4. Comparison 4 Constipation, Outcome 4 Symptom Analogue Score.

Symptom Analogue Score

\begin{tabular}{|c|c|c|c|c|c|c|c|c|}
\hline Study & Measure & Patients & Baseline & One year & 'Off' period & 'On' period & Change (\%) & Notes \\
\hline $\begin{array}{l}\text { Kenefick } \\
\text { 2002\# }\end{array}$ & $\begin{array}{l}\text { Mean } \\
\text { (range) }\end{array}$ & 2 & $\begin{array}{l}30 \quad(28 \text { and } \\
32)\end{array}$ & $\begin{array}{l}89 \text { (84 and } \\
94)\end{array}$ & $\begin{array}{l}32(30 \text { and } \\
33)\end{array}$ & $\begin{array}{l}74 \quad(60 \text { and } \\
88)\end{array}$ & $42(131 \%)$ & $\begin{array}{l}\text { The } \\
\text { score ranges } \\
\text { from a best } \\
\text { score of } 100 \\
\text { to a worst } \\
\text { score of } 0\end{array}$ \\
\hline
\end{tabular}

Sacral nerve stimulation for faecal incontinence and constipation in adults (Review)

Copyright @ 2015 The Cochrane Collaboration. Published by John Wiley \& Sons, Ltd. 
Analysis 4.5. Comparison 4 Constipation, Outcome 5 Anorectal manometry.

Anorectal manometry

\begin{tabular}{|c|c|c|c|c|c|c|c|}
\hline Study & Measure & Patients & Baseline & One year & 'Off' period & 'On' period & Notes \\
\hline \multicolumn{8}{|c|}{ Maximal resting pressure $\left(\mathrm{cm} \mathrm{H}_{2} \mathbf{0}\right)$} \\
\hline $\begin{array}{l}\text { Kenefick } \\
\text { 2002\# }\end{array}$ & Mean (range) & 2 & 75 (65 and 84) & 85 (82 and 87$)$ & $51(39$ and 63) & $76(68$ and 84$)$ & $\begin{array}{l}\text { Stationary pull- } \\
\text { through tech- } \\
\text { nique }\end{array}$ \\
\hline
\end{tabular}

Maximal squeeze pressure $\left(\mathrm{cm} \mathrm{H}_{2} \mathbf{0}\right)$

\begin{tabular}{l|l|l|l|l|l|l}
\hline $\begin{array}{l}\text { Kenefick } \\
2002 \#\end{array}$ & Mean (range) & 2 & $39(32$ and 46$)$ & $\begin{array}{l}78 \\
104)\end{array}$ & $(52$ and $54(51$ and 57$)$ & $\begin{array}{l}93 \\
145)\end{array}$ \\
\hline
\end{tabular}

Rectal volume sensation - threshold ( $\mathrm{ml}$ air)

\begin{tabular}{|c|c|c|c|c|c|c|}
\hline $\begin{array}{l}\text { Kenefick } \\
\text { 2002\# }\end{array}$ & Mean (range) & 2 & 46 (45 and 47) & $40(20$ and 60$)$ & $35(30$ and 40$)$ & $18(15$ and 20$)$ \\
\hline
\end{tabular}
2002\#

Rectal volume sensation - urge ( $\mathrm{ml}$ air)

\begin{tabular}{|c|c|c|c|c|c|c|}
\hline $\begin{array}{l}\text { Kenefick } \\
\text { 2002\# }\end{array}$ & Mean (range) & 2 & $\begin{array}{l}130 \quad(75 \text { and } \\
185)\end{array}$ & 55 (35 and 75) & $70(60$ and 80$)$ & $34(33$ and 35$)$ \\
\hline \multicolumn{7}{|c|}{ Rectal volume sensation - maximal tolerated (ml air) } \\
\hline $\begin{array}{l}\text { Kenefick } \\
\text { 2002\# }\end{array}$ & Mean (range) & 2 & $\begin{array}{l}194(143 \text { and } \\
245)\end{array}$ & $\begin{array}{l}83 \quad(65 \text { and } \\
100)\end{array}$ & $\begin{array}{l}103 \quad(85 \text { and } \\
120)\end{array}$ & $68(65$ and 70$)$ \\
\hline
\end{tabular}

Analysis 4.6. Comparison 4 Constipation, Outcome 6 Stool frequency (per week).

Stool frequency (per week)

\begin{tabular}{|c|c|c|c|c|c|c|c|}
\hline Study & Measure & Patients & Baseline & Off period & On period & Change (\%) & Notes \\
\hline $\begin{array}{l}\text { Dinning } \\
2015 \#\end{array}$ & Mean (SD) & 53 & $5.6(3.7)$ & $6.4(3.7)$ & $6.6(3.9)$ & $17.9 \%$ & $\begin{array}{l}\text { Off period is sham, and on period } \\
\text { is suprasensory stimulation }\end{array}$ \\
\hline
\end{tabular}

Analysis 4.7. Comparison 4 Constipation, Outcome 7 Pain score (weekly average).

Pain score (weekly average)

\begin{tabular}{|c|c|c|c|c|c|c|c|}
\hline Study & Measure & Patients & Baseline & Off period & On period & $\begin{array}{l}\text { Percentage change } \\
(\%)\end{array}$ & Notes \\
\hline
\end{tabular}


Pain score (weekly average) (Continued)

\begin{tabular}{|c|c|c|c|c|c|c|c|}
\hline $\begin{array}{l}\text { Dinning } \\
2015 \#\end{array}$ & Mean (SD) & 53 & $1.4(0.6)$ & $1.0(0.8)$ & $0.9(1.3)$ & $-35.7 \%$ & $\begin{array}{l}\text { Off period is sham, and } \\
\text { on period is suprasen- } \\
\text { sory stimulation }\end{array}$ \\
\hline
\end{tabular}

Analysis 4.8. Comparison 4 Constipation, Outcome 8 Bloating score (weekly average).

Bloating score (weekly average)

\begin{tabular}{lllllllll}
\hline Study & Measure & Patient & Baseline & Off period & On period & hange(\%) & Notes \\
\hline $\begin{array}{l}\text { Dinning } \\
2015 \#\end{array}$ & Mean (SD) & 53 & $1.6(0.6)$ & $1.2(0.7)$ & $1.2(0.7)$ & $-25 \%$ & $\begin{array}{l}\text { Off period is sham, and on period is } \\
\text { suprasensory stimulation }\end{array}$ \\
\hline
\end{tabular}

Analysis 4.9. Comparison 4 Constipation, Outcome 9 Quality of life - SF36.

Quality of life - SF36

\begin{tabular}{|c|c|c|c|c|c|c|c|c|c|c|}
\hline Study & Group & Measure & $\begin{array}{l}\text { Role - } \\
\text { emo- } \\
\text { tional }\end{array}$ & $\begin{array}{l}\text { General } \\
\text { health }\end{array}$ & $\begin{array}{l}\text { Mental } \\
\text { health }\end{array}$ & $\begin{array}{l}\text { Bodily } \\
\text { pain }\end{array}$ & $\begin{array}{l}\text { Phys- } \\
\text { ical func- } \\
\text { tioning }\end{array}$ & $\begin{array}{l}\text { Role- } \\
\text { physical }\end{array}$ & $\begin{array}{l}\text { Social } \\
\text { function }\end{array}$ & Vitality \\
\hline $\begin{array}{l}\text { Dinning } \\
2015 \#\end{array}$ & $\begin{array}{l}\text { Baseline } \\
(\mathrm{n}=59)\end{array}$ & $\begin{array}{l}\text { Mean } \\
(\mathrm{SD})\end{array}$ & $44(13)$ & $42(12)$ & $46(13)$ & $43(9)$ & $49(10)$ & $44(12)$ & $42(12)$ & $44(11)$ \\
\hline $\begin{array}{l}\text { Dinning } \\
2015 \#\end{array}$ & $\begin{array}{l}\text { Sham/ } \\
\text { Off } \quad(n= \\
53)\end{array}$ & $\begin{array}{l}\text { Mean } \\
(\mathrm{SD})\end{array}$ & $46(13)$ & $45(11)$ & $47(11)$ & $42(11)$ & $49(9)$ & $43(11)$ & $42(12)$ & $45(12)$ \\
\hline $\begin{array}{l}\text { Dinning } \\
2015 \#\end{array}$ & $\begin{array}{l}\text { Suprasen- } \\
\text { sory/On } \\
(\mathrm{n}=53)\end{array}$ & $\begin{array}{l}\text { Mean } \\
(\mathrm{SD})\end{array}$ & $49(8)$ & $46(10)$ & $48(10)$ & $45(9)$ & $51(8)$ & $48(10)$ & $46(11)$ & $46(10)$ \\
\hline
\end{tabular}

Analysis 4.10. Comparison 4 Constipation, Outcome 10 Adverse events.

Adverse events

\begin{tabular}{l|l|l}
\hline \multicolumn{1}{|l}{ Type } & Number of adverse events \\
\hline Dinning 2015\# & Implanted pulse generator site (IPG) related pain & 32 \\
\hline Dinning 2015\# & Wound infection & 12 \\
\hline Dinning 2015\# & Leg pain/discomfort & 4 \\
\hline Dinning 2015\# & Abdominal pain/discomfort & 3
\end{tabular}

Sacral nerve stimulation for faecal incontinence and constipation in adults (Review) 
Adverse events (Continued)

\begin{tabular}{ll|l}
\hline Dinning 2015\# & Urological & 17 \\
\hline Dinning 2015\# & Tachycardia & 1 \\
\hline Dinning 2015\# & Headache & 2 \\
\hline Dinning 2015\# & Altered mood & 2 \\
\hline
\end{tabular}

\section{ADDITIONAL TABLES}

Table 1. Episode of faecal incontinence per week (from Fraser 2004)

\begin{tabular}{|c|c|c|c|c|c|c|c|}
\hline Study id & Measure & Participants & Baseline & Follow-up & p-value & Change (\%) & Notes \\
\hline Ganio 2002 & Mean (range) & 31 & $7.5(1$ to 11$)$ & $0.15(0$ to 2$)$ & Not reported & $-7.35(-98 \%)$ & \\
\hline Jarrett 2004 & $\begin{array}{l}\text { Median } \\
\text { (range) }\end{array}$ & 46 & 7.5 (1 to 78$)$ & $1.00(0$ to 39$)$ & $<0.0001$ & $-6.50(-87 \%)$ & \\
\hline Leroi 2001 & Mean (SD) & 4 & $3.0(2.7)$ & $0.50(0.6)$ & Not reported & $-2.50(-83 \%)$ & \\
\hline Matzel 2003 & Median & 16 & $40 \%$ & $0 \%$ & $<0.001$ & & $\begin{array}{l}\text { Matzel and col- } \\
\text { leagues re- } \\
\text { ported the per- } \\
\text { centage } \\
\text { of bowel move- } \\
\text { ments that were } \\
\text { faecally incon- } \\
\text { tinent }\end{array}$ \\
\hline Rosen 2001 & $\begin{array}{l}\text { Median } \\
\text { (range) }\end{array}$ & 16 & 2.0 (1 to 5$)$ & $\begin{array}{l}0.67 \quad(0 \text { to } 1 . \\
67)\end{array}$ & Not reported & $-1.33(-67 \%)$ & \\
\hline Uludag 2002 & Mean & 34 & 8.66 & 0.67 & $<0.01$ & $-7.99(-92 \%)$ & \\
\hline MDT-301 & Mean (SD) & $37 ; 33$ & $16.4(19.3)$ & $2.7(4.8)$ & $<0.001$ & $\begin{array}{l}-13.70 \\
(-84 \%)\end{array}$ & $\begin{array}{l}\text { The number of } \\
\text { partici- } \\
\text { pants was } 37 \text { at } \\
\text { baseline and } 33 \\
\text { at follow-up }\end{array}$ \\
\hline
\end{tabular}




\section{A P P E N D I C E S}

\section{Appendix I. Search strategy for the Incontinence Group Specialised Register}

The Incontinence Group Specialised Register was searched using the Group's own keyword system; the search terms used were:

topic.faecal*

AND

(\{design.cct*\} OR \{design.rct*\})

AND

(\{intvent.surg.SNS\} OR \{intvent.phys.electstim.implanted\})

(All searches were of the keyword field of Reference Manager 2012).

Date of the most recent search of the register for this review: 5 February 2015.

\section{Appendix 2. Search strategy for Embase}

Embase on OvidSP (1 January 1947 to 2015 Week 5) was searched on 5 February 2015 using the search strategy given in below. Only the years 2010 to 2015 (inclusive) were searched as these years were not covered by the Cochrane Collaboration's centralised search of Embase for CENTRAL at this time .

1. Randomized Controlled Trial/

2. crossover procedure/ or double blind procedure/ or parallel design/ or single blind procedure/

3. Placebo/

4. placebo\$.tw,ot.

5. random $\$$.tw,ot.

6. ((singl\$ or doubl\$ or trebl\$ or tripl\$) adj25 (blind $\$$ or mask $\$))$.tw,ot.

7. crossover.tw,ot.

8. cross over\$.tw,ot.

9. allocat\$.tw,ot.

10. trial.ti.

11. parallel design/

12. triple blind procedure/

13. or/1-12

14. exp animals/ or exp invertebrate/ or animal experiment/ or animal model/ or animal tissue/ or animal cell/

15. exp human/ or exp "human tissue, cells or cell components"/

16. 14 and 15

17. 14 not 16

18. 13 not 17

19. continence/

20. (incontinen\$ or continen\$).tw.

21. incontinence/

22. feces incontinence device/

23. feces incontinence/

24. constipation/

25. constipat*.tw,ot.

26. dyschezia.tw,ot.

27. obstipat*.tw,ot.

28. 19 or 20 or 21 or 22 or 23 or 24 or 25 or 26 or 27

29. sacral nerve stimulation/

30. (sacral adj3 stimul*).tw,ot.

31. (sacral adj3 neuromodul*).tw,ot.

32. sns.tw,ot.

33. snm.tw,ot

34.29 or 30 or 31 or 32 or 33

35. $\left(2010^{*}\right.$ or $2011^{*}$ or $2012^{*}$ or $2013^{*}$ or $\left.2014^{*}\right)$.em.

Sacral nerve stimulation for faecal incontinence and constipation in adults (Review)

Copyright ( 2015 The Cochrane Collaboration. Published by John Wiley \& Sons, Ltd. 
36. 18 and 28 and 34

37.35 and 36

\section{WHAT'S NEW}

Last assessed as up-to-date: 5 February 2015.

\begin{tabular}{l|l|l}
\hline Date & Event & Description \\
\hline 17 August 2015 & New search has been performed & $\begin{array}{l}\text { Five new trials were added in this update (Sørensen } \\
\text { 2010\#; Tjandra 2008;Dinning 2015\#; Kahlke 2015\#; } \\
\text { Thin 2015). Risk of bias assessment was redone of all } \\
\text { included trials }\end{array}$ \\
\hline 17 August 2015 & New citation required but conclusions have not changed & $\begin{array}{l}\text { Five new trials were added in this update (Sørensen } \\
\text { 2010\#; Tjandra 2008;Dinning 2015\#; Kahlke 2015\#; } \\
\text { Thin 2015). Risk of bias assessment was redone of all } \\
\text { included trials }\end{array}$ \\
\hline
\end{tabular}

\section{H I S T O R Y}

Protocol first published: Issue 4, 2003

Review first published: Issue 3, 2007

\begin{tabular}{l|ll}
\hline Date & Event & Description \\
\hline 9 October 2008 & Amended & Converted to new review format. \\
\hline 23 May 2007 & New citation required and conclusions have changed & Substantive amendment \\
\hline 10 January 2006 & New search has been performed & Minor update \\
\hline
\end{tabular}

\section{CONTRIBUTIONSOFAUTHORS}

Amin Abukar and Mohamed A Thaha screened the search results, assessed full text studies for inclusion, and undertook data abstraction and quality assessment. Amin Abukar, Mohamed A Thaha and Charles Knowles drafted the review. Mohamed A Thaha, Noel Thin, Anthony Ramsanahie, and Charles Knowles provided advice on analysis and interpretation of data and commented on drafts of the review. Mohamed A Thaha and Charles Knowles provided clinical advice on aspects of the SNS procedure. 


\section{DECLARATIONSOF INTEREST}

Some members of the review author group (NNT, MAT, CHK) are authors of a recently-published overview on the wider topic of neuromodulation including SNS (Thin 2013). The Royal London Hospital's team under Professor Knowles heads many original clinical and methodological studies on neuromodulation, including SNS and PTNS.

\section{SOURCES OF SUPPORT}

\section{Internal sources}

- No sources of support supplied

\section{External sources}

- National Institute for Health Research (NIHR), UK.

This project was supported by the National Institute for Health Research, via Cochrane Infrastructure, Cochrane Programme Grant or Cochrane Incentive funding to the Incontinence Group. The views and opinions expressed therein are those of the authors and do not necessarily reflect those of the Systematic Reviews Programme, NIHR, NHS or the Department of Health.

\section{DIFFERENCES BETWEEN PROTOCOLANDREVIEW}

The current review is an update of the previous publication in 2007 (Mowatt 2007) and has included five extra trials.

\section{NDEX TERMS}

\section{Medical Subject Headings (MeSH)}

Constipation [*therapy]; Cross-Over Studies; Electric Stimulation Therapy [*methods]; Electrodes, Implanted; Fecal Incontinence [*therapy]; Outcome Assessment (Health Care); Sacrum; Spinal Nerves

\section{MeSH check words}

Adult; Female; Humans; Male 